\title{
The Chemistry of Carbon in Aqueous Fluids at Crustal and Upper-Mantle Conditions: Experimental and Theoretical Constraints
}

\author{
Craig E. Manning \\ Department of Earth and Space Sciences \\ University of California, Los Angeles \\ Los Angeles, California 90095, U.S.A. \\ manning@ess.ucla.edu \\ Everett L. Shock \\ School of Earth and Space Exploration \\ Arizona State University \\ Tempe, Arizona 85287-1404, U.S.A.
}

Everett.Shock@asu.edu

Dimitri A. Sverjensky

Department of Earth and Planetary Sciences

The Johns Hopkins University

Baltimore, Maryland 21218, U.S.A.

sver@jhu.edu

\section{INTRODUCTION}

Carbon can be a major constituent of crustal and mantle fluids, occurring both as dissolved ionic species (e.g., carbonate ions or organic acids) and molecular species (e.g., $\mathrm{CO}_{2}, \mathrm{CO}$, $\mathrm{CH}_{4}$, and more complex organic compounds). The chemistry of dissolved carbon changes dramatically with pressure $(P)$ and temperature $(T)$. In aqueous fluids at low $P$ and $T$, molecular carbon gas species such as $\mathrm{CO}_{2}$ and $\mathrm{CH}_{4}$ saturate at low concentration to form a separate phase. With modest increases in $P$ and $T$, these molecular species become fully miscible with $\mathrm{H}_{2} \mathrm{O}$, enabling deep crustal and mantle fluids to become highly concentrated in carbon. At such high concentrations, carbon species play an integral role as solvent components and, with $\mathrm{H}_{2} \mathrm{O}$, control the mobility of rock-forming elements in a wide range of geologic settings. The migration of carbon-bearing crustal and mantle fluids contributes to Earth's carbon cycle; however, the mechanisms, magnitudes, and time variations of carbon transfer from depth to the surface remain least understood parts of the global carbon budget (Berner 1991, 1994; Berner and Kothavala 2001).

Here we provide an overview of carbon in crustal and mantle fluids. We first review the evidence for the presence and abundance of carbon in these fluids. We then discuss oxidized and reduced carbon, both as solutes in $\mathrm{H}_{2} \mathrm{O}$-rich fluids and as major components of miscible $\mathrm{CO}_{2}-\mathrm{CH}_{4}-\mathrm{H}_{2} \mathrm{O}$ fluids. Our goal is to provide some of the background needed to understand the role of fluids in the deep carbon cycle. 


\section{Carbon in aqueous fluids of crust and mantle}

Numerous lines of evidence indicate that carbon may be an important component of crustal and mantle fluids. Fluid inclusions provide direct samples of carbon-bearing fluids from a range of environments. Carbon species in fluid inclusions include molecular gas species $\left(\mathrm{CO}_{2}\right.$, $\mathrm{CH}_{4}$ ), carbonate ions, and complex organic compounds, including petroleum (Roedder 1984). Carbon-bearing fluid inclusions occur in all crustal metamorphic settings, but they have also been reported in samples derived from mantle depths, including nearly pure $\mathrm{CO}_{2}$ inclusions in olivine in mantle xenoliths (Roedder 1965; Deines 2002), inclusions in ultrahigh-pressure metamorphic minerals exhumed from mantle depths (Fu et al. 2003b; Frezzotti et al. 2011), and carbon-bearing fluid inclusions in diamonds from depths corresponding to more than $5 \mathrm{GPa}$ (Navon et al. 1988; Schrauder and Navon 1993).

The formation of carbon-bearing minerals in fluid-flow features such as veins and segregations are prima facie indications of carbon transport by deep fluids. Environments in which carbonate veins have been observed range from shallow crustal settings to rocks exhumed from subduction zones (Gao et al. 2007) and, rarely, mantle xenoliths (Demeny et al. 2010). Graphite is also widely observed as a vein mineral, most famously perhaps in the Borrowdale graphite deposit of the Lake District in the United Kingdom (e.g., Barrenechea et al. 2009). The occurrence of C-bearing minerals in metamorphic veins is consistent with the observation that the $\mathrm{C}$ content of metamorphic rocks decreases with increasing metamorphic grade. For example, pelagic clay lithologies ("pelites") progressively decarbonate during metamorphism: whereas the global average oceanic sediment has $3.01 \mathrm{wt} \% \mathrm{CO}_{2}$, low-grade metapelites have an average of $2.31 \mathrm{wt} \% \mathrm{CO}_{2}$, and high-grade metapelites average $0.22 \mathrm{wt} \%$ $\mathrm{CO}_{2}$ (Shaw 1956; Plank and Langmuir 1998). The decarbonation correlates with dehydration, clearly demonstrating that prograde metamorphic reactions liberate a fluid phase containing both $\mathrm{H}_{2} \mathrm{O}$ and carbon as components. Similarly, the development of calc-silicate skarns in carbonate lithologies (Einaudi et al. 1981), in which fluid flow induces replacement of carbonate minerals (chiefly calcite) by silicates and oxides, requires liberation of carbon to water-rich fluids. Finally, spring waters discharging from active metamorphic terranes commonly contain carbon derived from depth (Irwin 1970; Chiodini et al. 1995; Chiodini et al. 1999; Becker et al. 2008; Wheat et al. 2008).

\section{Sources of carbon in aqueous fluids of the crust and mantle}

The carbon that is incorporated into deep fluids is derived from two sources. It may be liberated from the host rocks during fluid-rock reaction ("internal sources"), or it may be introduced by mixing with other fluids ("external sources").

Internal carbon sources. Oxidized carbon is incorporated into rocks by primary accumulation and crystallization processes, and by secondary weathering, alteration, or cementation processes. The dominant primary internal source of oxidized carbon is sedimentary. Pure limestone generated by accumulation of biomineralized calcite (shells, etc.) contains 44 wt $\% \mathrm{CO}_{2}$, whereas dolomite contains $48 \mathrm{wt} \% \mathrm{CO}_{2}$. Varying amounts of siliciclastic detritus found in "impure" carbonates lowers the $\mathrm{CO}_{2}$ concentration. The carbonate compensation depth limits the accumulation of carbon in pelagic sediments. But even deep-ocean sedimentary packages contain at least some $\mathrm{CO}_{2}$ : the global average composition of oceanic sediment entering subduction zones is $3.01 \pm 1.44 \mathrm{wt} \% \mathrm{CO}_{2}$ (Plank and Langmuir 1998). In addition, calcite is one of the most common cements found in sandstone. Carbonate minerals are rare products of magmatic crystallization of silicate magmas, though they occur as primary phases in C-rich magmas such as carbonatites and kimberlites (Jones et al. 2013). Carbonate minerals have been observed as inclusions in silicate minerals in mantle xenoliths (e.g., McGetchin and Besancon 1973). 
Near Earth's surface, secondary processes can enrich igneous, metamorphic, and sedimentary lithologies in $\mathrm{CO}_{2}$ by weathering and alteration. On continents, rock weathering extracts $\mathrm{CO}_{2}$ from the atmosphere to produce secondary carbonate minerals (Urey 1952; Berner et al. 1983). In submarine settings, seafloor alteration processes lead to significant $\mathrm{CO}_{2}$ uptake by secondary carbonation of basaltic crust. For example, fresh mid-ocean ridge basalt (MORB) is estimated to contain $\sim 0.15 \mathrm{wt} \% \mathrm{CO}_{2}$, but during alteration and seafloor weathering the $\mathrm{CO}_{2}$ content of the upper $600 \mathrm{~m}$ of the oceanic crust may increase to $\sim 3 \mathrm{wt} \%$, and the average $\mathrm{CO}_{2}$ gain by the entire crustal section is elevated to $\sim 0.4 \mathrm{wt} \%$ (Staudigel 2003). Abundant carbonate veins in oceanic serpentinites are observed in core, dredge hauls, and ophiolites, indicating that altered oceanic mantle rocks likewise contain significant carbon (e.g., Thompson et al. 1968; Thompson 1972; Bonatti et al. 1974, 1980; Trommsdorff et al. 1980; Morgan and Milliken 1996; Schrenk et al. 2013).

The most common source of reduced carbon is buried organic material found in sedimentary lithologies. Carbon in sedimentary basins is present in a variety of species and phases that span a substantial range of redox states. Familiar organic compounds found in sedimentary basins include the fossil fuels such as coal, petroleum, and natural gas, which typically have their origins in the transformation of detrital organic remains of life (Sephton and Hazen 2013). The biomolecules that accumulate with mineral grains in sediments and sedimentary rocks are those compounds that are most resistant to microbial modification. The most refractory compounds are membrane molecules of microbes and lignin molecules from plants, which can be transformed into petroleum or coal, respectively, if the subsurface geologic conditions are conducive. Through a complex series of reactions, these compounds may transform to graphite during crustal metamorphism. This graphite can be an important source for carbon in metamorphic fluids.

Condensed zero-valent and reduced carbon occurs in mantle rocks in a variety of forms (Mathez et al. 1984). It is found as a free phase as graphite or diamond, or as carbide minerals such as moissanite, cementite or other Fe-C compounds (Dasgupta and Hirschmann 2010; Shiryaev et al. 2011; Hazen et al. 2013). Small amounts of carbon may dissolve in mantle minerals (Tingle and Green 1987; Tingle et al. 1988; Keppler et al. 2003; Shcheka et al. 2006; Ni and Keppler 2013) or coat grain surfaces (Mathez 1987; Pineau and Mathez 1990; Mathez and Mogk 1998).

External carbon sources. The carbon in a system experiencing fluid-mineral interaction need not be solely internally derived from the local rock host. Fluids carrying carbon from external sources may mix with an otherwise carbon-free fluid. At least at depths above the brittle-ductile transition, meteoric waters drawn downward by hydrothermal or metamorphic circulation may carry atmosphere-derived carbon. Magmas also represent a potentially important carbon source. Carbon in volcanic gases typically occurs as $\mathrm{CO}_{2}$; reduced species such as $\mathrm{CO}$ and $\mathrm{CH}_{4}$ are very low in abundance (Symonds et al. 1994; Burton et al. 2013). Pre-eruptive $\mathrm{CO}_{2}$ contents of the main types of mafic magmas are 2000-7000 ppm in ocean island basalts and $\sim 1500 \mathrm{ppm}$ in normal MORB (Marty and Tolstikhin 1998; Gerlach et al. 2002; Oppenheimer 2003; Dasgupta 2013; Ni and Keppler 2013). Andesite exhibits a wide range of pre-eruptive $\mathrm{CO}_{2}$, from below detection to $2500 \mathrm{ppm}$ (Wallace 2005), and $\mathrm{CO}_{2}$ is typically below detection in silicic magmas such as dacites and rhyolites (Oppenheimer 2003). Carbonatite and carbonated silicate magmas, though rare, carry substantial carbon and may act as a carbon source where they trigger production of more common magmas (Dasgupta and Hirschmann 2006; Jones et al. 2013).

Although inferred pre-eruptive carbon contents of the more common magma types are generally low, molecular carbon species are strongly partitioned into the vapor phase when magmas reach saturation. This fractionation means that substantial carbon may be lost prior to entrapment of melt inclusions or liberation of volcanic gas, both of which form the basis for 
estimates of the above volatile abundances. In many cases, concentration estimates are therefore simply lower bounds. This factor may be particularly important in convergent margins and orogenic belts. For example, Blundy et al. (2010) proposed early saturation of $\mathrm{CO}_{2}$ and more $\mathrm{CO}_{2}$-rich arc magmas than previously assumed. The occurrence of magmatic calcite inclusions in granitoids is a test of this idea. Audétat et al. (2004) describe magmatic calcite inclusions in quartz and apatite in a quartz monzodioritic dike at Santa Rita, New Mexico. Calcite on the liquidus in granitic systems requires crystallization at depths of at least $10 \mathrm{~km}$ (Swanson 1979; Audétat et al. 2004), at conditions of high $\mathrm{CO}_{2}$ partial pressure. The Santa Rita example suggests that, at least locally, very high carbon contents may in fact occur in felsic systems. Rare carbonate-bearing scapolite that is rich in meionite component $\left[\mathrm{Ca}_{4} \mathrm{Al}_{6} \mathrm{Si}_{6} \mathrm{O}_{24}\left(\mathrm{CO}_{3}\right)\right]$ has been reported from a range of volcanic and plutonic rock types (Goff et al. 1982; Mittwede 1994; Smith et al. 2008).

Carbon contents may also be particularly high in alkaline and peralkaline magmatic systems due to elevated carbonate solubility (Koster van Groos and Wyllie 1968). Alkali carbonate/bicarbonate-rich fluids have been reported from numerous granitic pegmatites (Anderson et al. 2001; Sirbescu and Nabelek 2003a,b; Thomas et al. 2006, 2011). Evidence is chiefly the presence of fluid and melt inclusions containing carbonate daughter minerals such as nahcolite $\left(\mathrm{Na}_{2} \mathrm{CO}_{3}\right)$, zabuyelite $\left(\mathrm{Li}_{2} \mathrm{CO}_{3}\right)$, and even potassium carbonate $\left(\mathrm{K}_{2} \mathrm{CO}_{3}\right)$. In a detailed study, Thomas et al. (2011) report evidence for pegmatite emplacement from a three-phase fluid system of hydrous carbonate melt, a hydrous carbonate-saturated silicate melt, and $\mathrm{CO}_{2-}$ rich vapor. Total carbonate species concentrations in the vapor phase may exceed 30-40 $\mathrm{wt} \%$. These observations demonstrate that magmatic systems represent an important, though highly variable, source of carbon in the geologic environment through which they pass.

Finally, mantle degassing may provide an important source of carbon (Burton et al. 2013; Dasgupta 2013). Evidence for mantle fluids in deep environments is typically obscured by more voluminous fluids sourced from crustal rocks. However, fluid inclusions in mantle xenoliths record evidence for reduced carbon species, including $\mathrm{CH}_{4}, \mathrm{CO}$, and, potentially, COS (Melton et al. 1972; Melton and Giardini 1974; Murck et al. 1978; Bergman and Dubessy 1984; Tomilenko et al. 1998). In addition, carbonate-metasomatized shear zones of the deep crust display mantle-like $\mathrm{C}, \mathrm{Sr}$, and $\mathrm{He}$ isotope ratios, leading to the inference that components of the fluids that deposited the carbonates were initially of mantle origin (Baratov et al. 1984; Lapin et al. 1987; Stern and Gwinn 1990; Dahlgren et al. 1993; Dunai and Touret 1993; Oliver et al. 1993; Wickham et al. 1994).

\section{OXIDIZED CARBON IN AQUEOUS FLUIDS AT HIGH $P$ AND $T$}

A vast body of experimental and theoretical work has shown that in pure $\mathrm{H}_{2} \mathrm{O}$ at ambient conditions and along the liquid-vapor saturation curve, species of oxidized carbon dissolved in pure $\mathrm{H}_{2} \mathrm{O}$ include carbonate ion $\left(\mathrm{CO}_{3}{ }^{2-}\right)$, bicarbonate ion $\left(\mathrm{HCO}_{3}{ }^{-}\right)$, and dissolved $\mathrm{CO}_{2}\left(\mathrm{CO}_{2, \mathrm{aq}}\right.$; Fig. 1). A fourth possible species, "true" carbonic acid $\left(\mathrm{H}_{2} \mathrm{CO}_{3}\right.$; Fig. 1), has been isolated as a pure gas and solid (e.g., Terlouw et al. 1987), but decomposes rapidly in $\mathrm{H}_{2} \mathrm{O}$, such that the reaction

$$
\mathrm{H}_{2} \mathrm{CO}_{3}=\mathrm{CO}_{2, \mathrm{aq}}+\mathrm{H}_{2} \mathrm{O}
$$

proceeds far to the right; for example, at room $T$ and $P, \mathrm{H}_{2} \mathrm{CO}_{3}$ concentration is about $\sim 0.1 \%$ of $\mathrm{CO}_{2 \text {,aq }}$ (Loerting et al. 2000; Ludwig and Kornath 2000; Tossell 2006; England et al. 2011). Detection of these low concentrations of $\mathrm{H}_{2} \mathrm{CO}_{3}$ in aqueous solutions has now been convincingly achieved (Falcke and Eberle 1990; Soli and Byrne 2002; Adamczyk et al. 2009). Nevertheless, because of its very low concentration, geochemists conventionally treat the carbon present in both hydrated neutral species as $\mathrm{CO}_{2, \mathrm{aq}}$. 


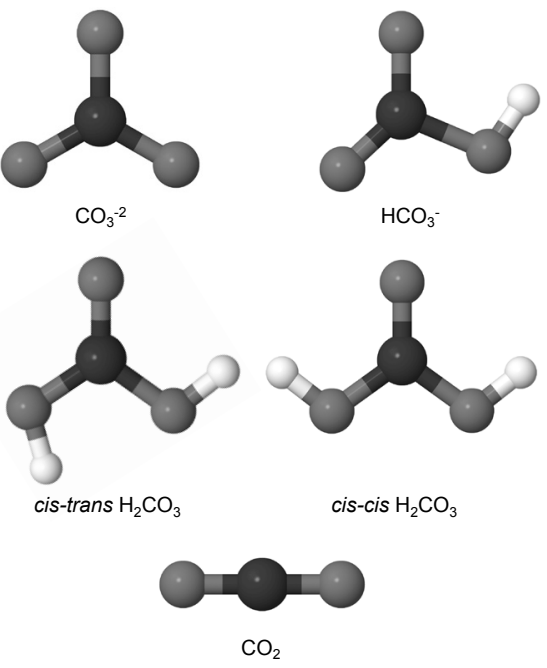

Figure 1. Gas-phase structures of the main oxidized-carbon species found in deep aqueous fluids. Carbon atoms are black, oxygen atoms gray, and hydrogen atoms white. The carbonate ion $\left(\mathrm{CO}_{3}{ }^{2-}\right)$ has trigonal planar structure. The $\mathrm{C}-\mathrm{O}$ bond distance is $0.131 \mathrm{~nm}$ and the bond angle is $120^{\circ}$. One of the three $\mathrm{C}-\mathrm{O}$ bonds is a double bond. In bicarbonate $\left(\mathrm{HCO}_{3}{ }^{-}\right)$, the hydration of an oxygen atom lengthens the corresponding $\mathrm{C}-\mathrm{O}$ bond and all bond angles rotate slightly to accommodate. The cis-cis carbonic acid $\left(\mathrm{H}_{2} \mathrm{CO}_{3}\right)$ structure is more stable than the cis-trans variant (e.g., Mori et al. 2011); the unhydrated oxygen shares a double bond with carbon. Carbon dioxide $\left(\mathrm{CO}_{2}\right)$ is a linear molecule with double $\mathrm{C}-\mathrm{O}$ bonds that are $0.16 \mathrm{~nm}$ in length.
The predominant oxidized carbon species interact via two stepwise dissociation reactions. The first involves generation of bicarbonate from $\mathrm{CO}_{2, \text { aq }}$ and a solvent $\mathrm{H}_{2} \mathrm{O}$ molecule:

$$
\mathrm{CO}_{2, \mathrm{aq}}+\mathrm{H}_{2} \mathrm{O}=\mathrm{HCO}_{3}^{-}+\mathrm{H}^{+}
$$

The second stepwise dissociation reaction is

$$
\mathrm{HCO}_{3}{ }^{-}=\mathrm{CO}_{3}{ }^{2-}+\mathrm{H}^{+}
$$

Figure $2 \mathrm{a}$ shows that at ambient conditions, neutral $\mathrm{pH}$ of $\mathrm{H}_{2} \mathrm{O}$ lies between $\mathrm{p} K_{2}$ and $\mathrm{p} K_{3}$, where $\mathrm{p} K_{i}$ is the negative logarithm of the equilibrium constant $K$ of reaction $i$. Thus, bicarbonate will often be the predominant species when $\mathrm{pH}$ is fixed independently of the carbon system.

Natural crustal and mantle solutions are complex, and contain substantial dissolved metal cations. These may interact with carbonate ions to form ion pairs such as $\mathrm{NaCO}_{3}{ }^{-}$, $\mathrm{CaCO}_{3}{ }^{\circ}$, or $\mathrm{CaHCO}_{3}{ }^{+}$. But dissolved oxidized carbon chemistry will vary strongly with geologic environment even in dilute aqueous solutions, because the $\mathrm{p} K$ values and the equilibrium constant for $\mathrm{H}_{2} \mathrm{O}$ dissociation are strong functions of $P$ and $T$. Thus, as illustrated in Figure $2 b$, the predominant species can be expected to change in deep crustal and mantle settings.

\section{Aqueous fluids at high $P$ and $T$}

Experimental constraints on homogeneous systems. Whereas there is a voluminous literature on aqueous carbonate ion speciation at ambient conditions and along the liquid-

vapor saturation curve of $\mathrm{H}_{2} \mathrm{O}$, there have been few direct studies of homogenous aqueous carbonate systems at high $P$ and $T$. This lack is chiefly due to the experimental challenges posed by working at these conditions. Read (1975) appears to have been the first experimentalist to examine aqueous carbonate equilibria at pressures greater than a few hundred atmospheres. Extending earlier work by Ellis (1959a) and Ryzhenko (1963), he used electrical conductivity measurements to $250^{\circ} \mathrm{C}$ and $0.2 \mathrm{GPa}$ (=2 kbar) to determine the equilibrium constant for reaction (2):

$$
K=\frac{a_{\mathrm{HCO}_{3}^{-}} a_{\mathrm{H}^{+}}}{a_{\mathrm{CO}_{2}, a q} a_{\mathrm{H}_{2} \mathrm{O}}}
$$

The results revealed that $K$ rises with increasing $P$ at constant $T$, but drops with increasing $T$ at constant $P$. Thus, reaction (2) is driven to the right on isothermal compression, but to the left on isobaric heating.

Kruse and Franck (1982) compressed $\mathrm{KHCO}_{3}$ solutions at up to $300{ }^{\circ} \mathrm{C}$ and $50 \mathrm{MPa}$, and used Raman spectroscopy to show that $\mathrm{CO}_{3}{ }^{2-}$ is favored relative to $\mathrm{HCO}_{3}{ }^{-}$. Frantz (1998) 

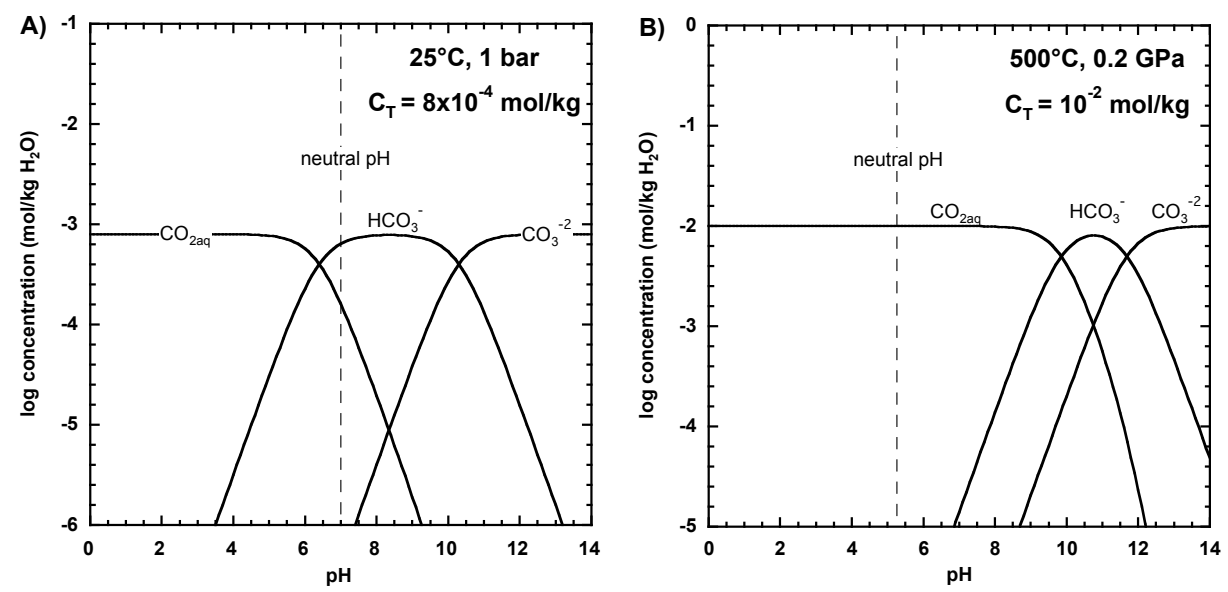

Figure 2. Variation in the abundances of the main oxidized carbon species with $\mathrm{pH}$ at $25{ }^{\circ} \mathrm{C}, 1 \mathrm{bar}(\mathrm{A})$, and $500{ }^{\circ} \mathrm{C}, 0.2 \mathrm{GPa}(\mathrm{B})$. Calculations assume unit activity coefficients of all species; data are from Shock et al $(1989,1997 b)$. Total carbon concentration $\left(C_{T}\right)$ in $(A)$ is $8 \times 10^{-4}$ molal, the global average riverine bicarbonate concentration (Garrels and Mackenzie 1971). In (B), $\mathrm{C}_{\mathrm{T}}$ is set to $10^{-2}$ molal. Vertical dashed line shows neutral $\mathrm{pH}$ at each set of conditions. Comparison of $(\mathrm{A})$ and $(\mathrm{B})$ highlight that the $\mathrm{pH}$ range over which $\mathrm{HCO}_{3}{ }^{-}$is stable decreases as $P$ and $T$ rise.

used a similar approach on 1 molal $\mathrm{K}_{2} \mathrm{CO}_{3}$ and $\mathrm{KHCO}_{3}$ solutions. He studied solutions along two isobars of 0.1 and $0.2 \mathrm{GPa}$, to 550 ${ }^{\circ} \mathrm{C}$. When adjusted for Raman scattering cross-section ratios, the results support isobaric decreases in $\mathrm{HCO}_{3}{ }^{-}$relative to $\mathrm{CO}_{2, \mathrm{aq}}$ and $\mathrm{CO}_{3}{ }^{2-}$ (Fig. 3). Martinez et al. (2004) studied 0.5 and $2 \mathrm{~m} \mathrm{~K}_{2} \mathrm{CO}_{3}$ solutions in a diamond cell. Raman spectra in runs to 400 ${ }^{\circ} \mathrm{C}$ and $0.03 \mathrm{GPa}$ indicated the presence of $\mathrm{CO}_{3}{ }^{2-}$, but not $\mathrm{HCO}_{3}{ }^{-}$. They inferred that $\mathrm{HCO}_{3}{ }^{-}$stability decreases significantly at high pressure. Thus, it appears that bicarbonate ion becomes less stable relative to $\mathrm{CO}_{2, \text { aq }}$ and carbonate ion as $P$ and $T$ rise to crustal and mantle conditions.

None of the spectroscopic studies yielded evidence for metal-carbonate ion pairing, although the solutions were relatively dilute. In addition, no evidence has been found for carbonic acid, consistent with results at ambient conditions (e.g., Davis and Oliver 1972); however, Falcke and Eberle (1990) found evidence of $\mathrm{H}_{2} \mathrm{CO}_{3}$ at high ionic strengths. The significantly higher ionic strengths of high $P$-T solutions (Manning 2004) means that this species may yet be significant at these conditions. Finally, there is not yet any evidence of other species in high $P-T$ aqueous solutions. For example, it has been suggested that dicarbonate ion $\left(\mathrm{C}_{2} \mathrm{O}_{5}{ }^{2-}\right)$ may be produced by reaction of carbonate ion with $\mathrm{H}_{2} \mathrm{O}$ :

$$
2 \mathrm{CO}_{3}{ }^{2-}+\mathrm{H}_{2} \mathrm{O}=\mathrm{C}_{2} \mathrm{O}_{5}{ }^{2-}+2 \mathrm{OH}^{-}
$$


(Zeller et al. 2005). Although dicarbonate ions may form when $\mathrm{CO}_{2}$ dissolves into carbonate melts via

$$
\mathrm{CO}_{2}+\mathrm{CO}_{3}{ }^{2-}=\mathrm{C}_{2} \mathrm{O}_{5}{ }^{2-}
$$

(Claes et al. 1996), there is as yet no evidence for this species in relevant geological fluids at crustal or mantle conditions.

Experimental studies of carbonate mineral solubility in $\mathrm{H}_{2} \mathrm{O}$. The most voluminous source of information on oxidized carbon species in aqueous solutions comes from studies of the solubility of carbonate minerals in $\mathrm{H}_{2} \mathrm{O}$ and mixed solvents. In general, experimental work has focused on the solubility of divalent metal carbonates, chiefly calcite, because carbonate minerals involving monovalent or trivalent cations are highly soluble or require extremely acidic $\mathrm{pH}$, respectively (Rimstidt 1997). The solubility of carbonate minerals in $\mathrm{H}_{2} \mathrm{O}$ is strongly dependent on $\mathrm{pH}$, regardless of $P$ and $T$ (Fig. 4). However, when carbonate minerals dissolve in initially pure $\mathrm{H}_{2} \mathrm{O}$, the solute products shift $\mathrm{pH}$ to a value that is more alkaline than neutral $\mathrm{pH}$ at the conditions of interest. Hence, all carbonate minerals contribute alkalinity to crustal and mantle fluids. We focus first on calcite in $\mathrm{H}_{2} \mathrm{O}$, then other minerals in $\mathrm{H}_{2} \mathrm{O}$, then carbonate minerals in more complex solutions.

Numerous studies investigated calcite solubility in $\mathrm{H}_{2} \mathrm{O}\left(\mathrm{CO}_{2}\right.$-free or equilibrated with the atmosphere) at low $P$ and $T$ along the $\mathrm{H}_{2} \mathrm{O}$ liquid-vapor saturation curve and up to $0.1 \mathrm{GPa}$ (Wells 1915; Frear 1929; Schloemer 1952; Morey 1962; Segnit 1962; Plummer 1982). The results showed that calcite dissolution in pure $\mathrm{H}_{2} \mathrm{O}$ is congruent, and that solubility decreases with increasing temperature isobarically and along the $\mathrm{H}_{2} \mathrm{O}$ boiling curve- the wellknown "reverse solubility" effect for calcite.

There are only 3 studies of calcite solubility in $\mathrm{H}_{2} \mathrm{O}$ at higher $P$ and $T$ appropriate for metamorphism and mantle fluids (Fig. 5). Walther and Long (1986) reported initial results at $0.1-0.3 \mathrm{GPa}, 300-600{ }^{\circ} \mathrm{C}$. They observed that solubility decreased with increasing temperature at 0.1-0.2 GPa; however at $0.3 \mathrm{GPa}$ solubility was constant or increased slightly with temperature. Fein and Walther (1989) later showed that the solubilities of Walther and Long (1986) were too low because they used less accurate post-experiment analytical procedures.
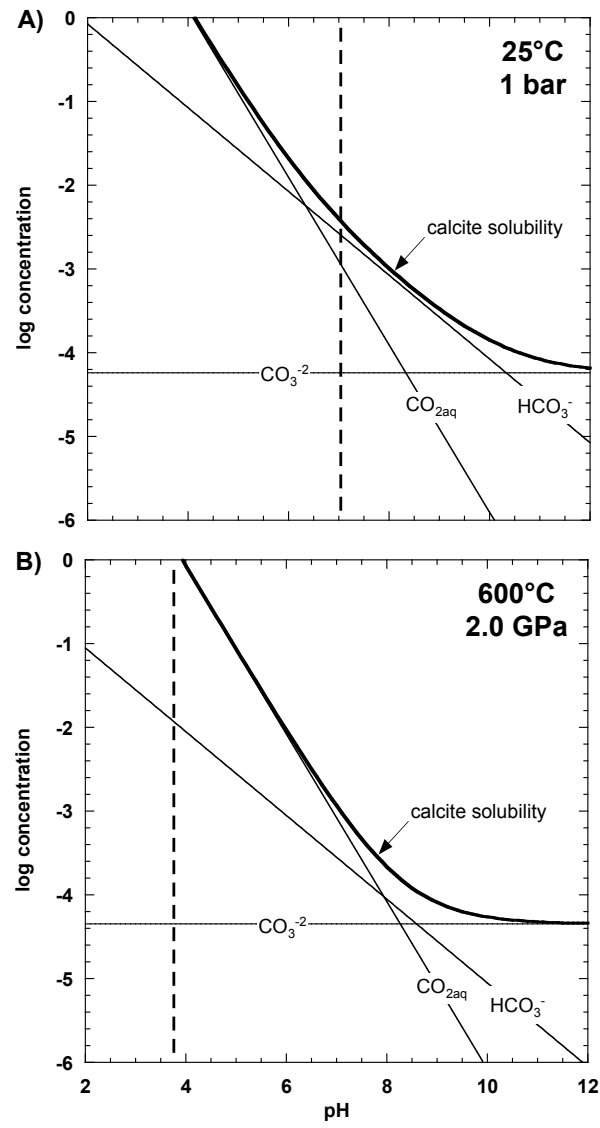

Figure 4. Calcite solubility in pure $\mathrm{H}_{2} \mathrm{O}$ at $25{ }^{\circ} \mathrm{C}, 1$ bar (A) and $600{ }^{\circ} \mathrm{C}, 2.0 \mathrm{GPa}(\mathrm{B})$, as a function of $\mathrm{pH}$. Calcite solubility (bold lines) is the sum of the concentrations of each constituent carbonate species (light lines). The general form of the solubility curves and the solubility at high $\mathrm{pH}$ are very similar. However the increase in the equilibrium constant for $\mathrm{H}_{2} \mathrm{O}$ dissociation with $P$ and $T$ leads to an increase in calcite solubility in near-neutral fluids. 


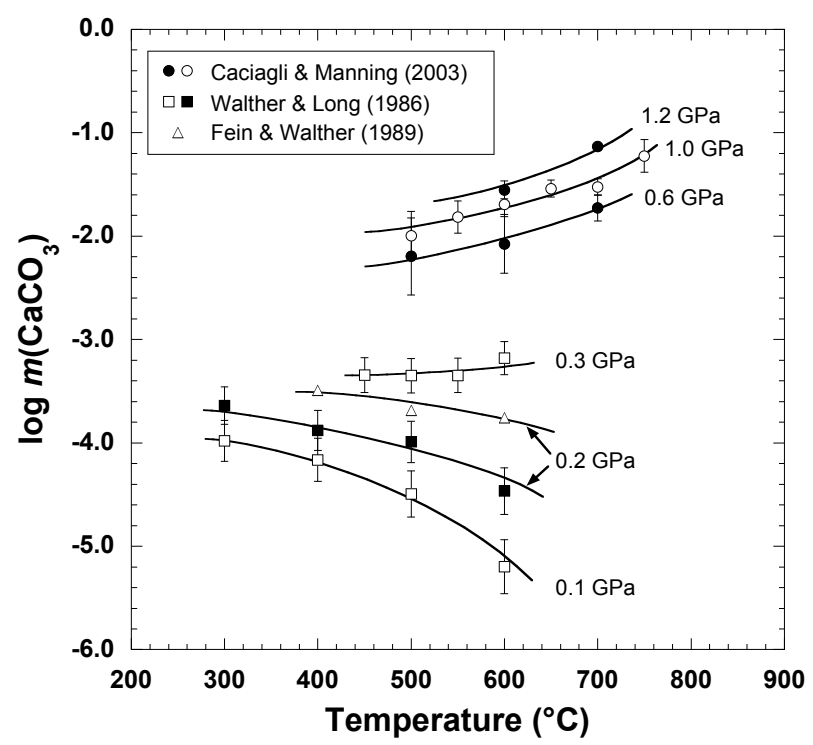

Figure 5. Summary of high-pressure determinations of calcite solubility in $\mathrm{H}_{2} \mathrm{O}$. Solubilities in molality.

However, the revised results yield similar solubility trends at $0.2 \mathrm{GPa}$ (Fig. 5). Caciagli and Manning (2003) extended these studies to deep crustal and mantle pressures (Fig. 5). Their data confirm that at high pressure calcite exhibits an isobaric rise in solubility with temperature.

Calcite transforms to aragonite at high pressure (Boettcher 1968; Johannes 1971); no studies have yet investigated aragonite solubility directly, though Caciagli and Manning (2003) extrapolated their results into the aragonite stability field. Lennie (2005) found that, at ambient $T$, ikaite $\left(\mathrm{CaCO}_{3} \cdot 6 \mathrm{H}_{2} \mathrm{O}\right)$ was stable with respect to calcite $+\mathrm{H}_{2} \mathrm{O}$; however, solubility data were not obtained.

Although solubilities of a wide range of metal carbonate minerals in $\mathrm{H}_{2} \mathrm{O}$ have been investigated at low pressures and temperatures (below $0.1 \mathrm{GPa}$ ), high-pressure studies are rare. Sanchez-Valle et al. (2003) combined hydrothermal diamond anvil cell (HDAC) methods with synchrotron X-ray fluorescence spectroscopy to determine $\mathrm{SrCO}_{3}$ solubility in $\mathrm{H}_{2} \mathrm{O}$ to 3.6 $\mathrm{GPa}$ and $525^{\circ} \mathrm{C}$. Strontianite was used because a high atomic number was required to obtain sufficiently favorable detection limits. Heating/compression runs in the HDAC revealed that strontianite solubility increases with pressure and temperature. Maximum solubility at 3.3-3.6 $\mathrm{GPa}$ and $475-525{ }^{\circ} \mathrm{C}$ was $\sim 0.2 \mathrm{~mol} / \mathrm{kg} \mathrm{H}_{2} \mathrm{O}$. Siderite $\left(\mathrm{FeCO}_{3}\right)$ dissolution in $\mathrm{H}_{2} \mathrm{O}$ has been studied to $400{ }^{\circ} \mathrm{C}$ and $1.13 \mathrm{GPa}$ in the HDAC (Marocchi et al. 2011), but the acquired Raman spectra were not used to determine quantitative solubility values.

The paucity of data on the dissolution of simple carbonate minerals in pure $\mathrm{H}_{2} \mathrm{O}$ at the high pressures presents serious challenges for testing thermodynamic models of carbonate ions and mineral solubility (see below). However, the hydrothermal piston-cylinder methods (e.g., Caciagli and Manning 2003) in parallel with hydrothermal diamond anvil cell methods (Sanchez-Valle et al. 2003) hold promise for generating such data in the near future.

Experimental studies of calcite solubility in $\mathrm{NaCl}-\mathrm{H}_{2} \mathrm{O}$. Studies at $\mathrm{P}<0.1 \mathrm{GPa}$ show that calcite solubility in $\mathrm{H}_{2} \mathrm{O}$ increases with addition of $\mathrm{NaCl}$ (Ellis 1963; Malinin 1972). Fein and Walther (1989) extended these studies to higher pressure of $0.2 \mathrm{GPa}$ and temperature up to $600{ }^{\circ} \mathrm{C}$. They showed that with addition of up to $0.1 \mathrm{~m} \mathrm{NaCl}$, calcite solubility increased 
consistent with formation of $\mathrm{CaCl}^{+}$in solution (Fig. 6). Newton and Manning (2002a) conducted experiments on calcite solubility in $\mathrm{H}_{2} \mathrm{O}-\mathrm{NaCl}$ at $600-900{ }^{\circ} \mathrm{C}, 1.0 \mathrm{GPa}$, and to highly concentrated $\mathrm{NaCl}$ solutions approaching halite saturation. They showed that calcite solubility increased with $\mathrm{NaCl}$ at all investigated conditions (Fig. 7). The pressure, temperature, and composition dependence of calcite molality $\left(m_{\mathrm{CaCO}_{3}}\right)$ are described by

$$
m_{\mathrm{CaCO}_{3}}=\left[-0.051+1.65 \times 10^{-4} T+X_{\mathrm{NaCl}}^{2} \exp \left(-3.071+4.749 \times 10^{-6} T^{2}\right)\right](0.76+0.024 P)
$$

with $P$ in kbar $(1 \mathrm{kbar}=0.1 \mathrm{GPa})$ and $T$ in kelvins. The solubility increase with temperature and salinity is so great that critical mixing of $\mathrm{NaCl}$-rich hydrous carbonate liquid and $\mathrm{CaCO}_{3}-$ rich saline solution was proposed at $1.0 \mathrm{GPa}$ at about $1000{ }^{\circ} \mathrm{C}$ and $\mathrm{NaCl}$ mole fraction $\left(X_{\mathrm{NaCl}}\right)$ of $\sim 0.4$.

The enhancement of solubility increases dramatically with temperature at constant $X_{\mathrm{NaCl}}$. Experiments at $0.6,1.0$, and $1.4 \mathrm{GPa}$ revealed a slight increase with pressure $(\sim 20 \%)$ at fixed $X_{\mathrm{NaCl}}$. Moreover, Newton and Manning's solubility data display a simple dependence on the

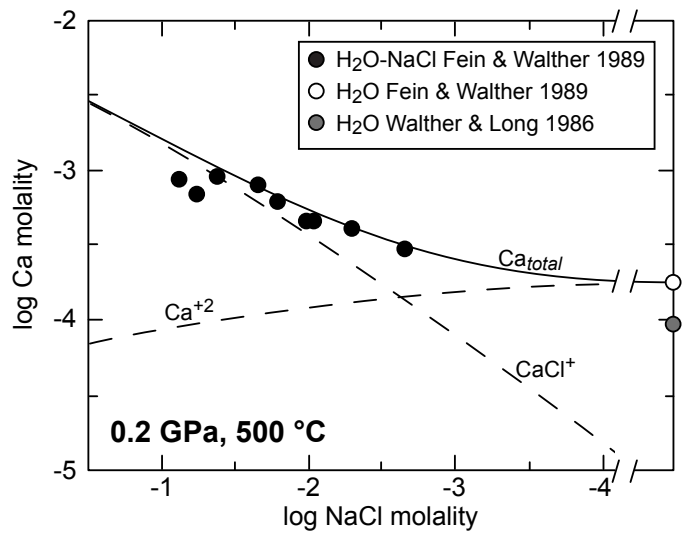

Figure 6. Dependence of calcite solubility on $\mathrm{NaCl}$ concentration at $500{ }^{\circ} \mathrm{C}, 0.2 \mathrm{GPa}$ (after Fein and Walther 1989). Calcite solubility, expressed as total dissolved $\mathrm{Ca}$, increases with increasing $\mathrm{NaCl}$. The corresponding rise in total chloride results in $\mathrm{Ca}-\mathrm{Cl}$ ion pairing; however, no evidence of $\mathrm{Na}$-carbonate pairing was observed. Solubility in pure $\mathrm{H}_{2} \mathrm{O}$ plots at $-\infty$, to right of break in scale.

Figure 7. Experimentally determined $\mathrm{CaCO}_{3}$ molality at $1.0 \mathrm{GPa}$, as a function of $\mathrm{NaCl}$ mole fraction (after Newton and Manning 2002a). Vertical size of rectangles reflects the range between maximum and minum solbility from a The 600,700 , and $800{ }^{\circ} \mathrm{C}$ curves are extrapolated to halite saturation (filled circles) in the system $\mathrm{NaCl}-\mathrm{H}_{2} \mathrm{O}$ (Aranovich and Newton 1996), ignoring dissolved $\mathrm{CaCO}_{3}$.

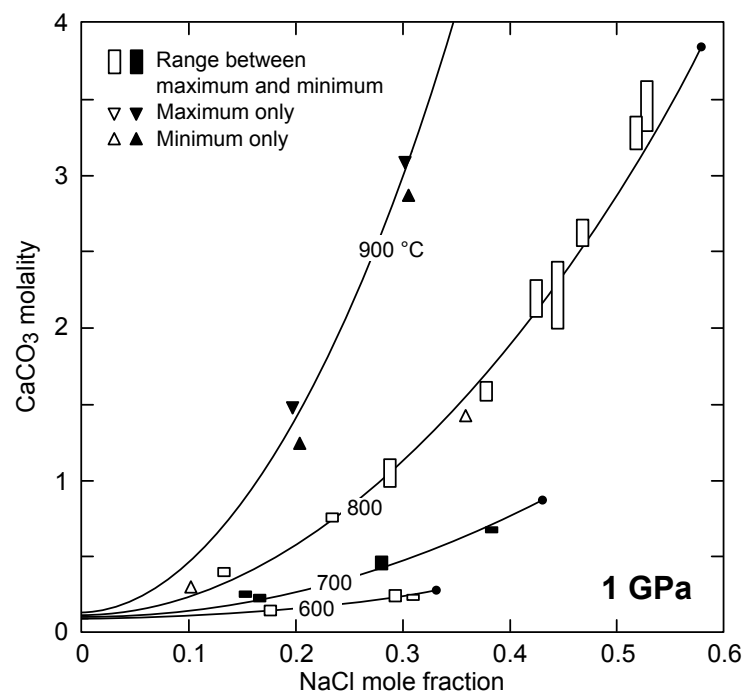


square of the $\mathrm{NaCl}$ mole fraction. This result has important implications for the nature of carbon and other solutes. An increase in solubility over the entire investigated range shows that the solute species are not hydrous; if they were, their concentrations would be required to decline with rising $\mathrm{NaCl}$ in concert with decreasing $\mathrm{H}_{2} \mathrm{O}$ activity. These concentrated solutions behave in a manner similar to molten salts (Newton and Manning 2002a, 2005; Tropper and Manning 2007), in which the activity of $\mathrm{NaCl}$ is proportional to the square of its mole fraction (Aranovich and Newton 1996), and solute mixing is nearly ideal. This result led to the inference that the dissolution reaction, written in terms of predominant species, was

$$
\mathrm{CaCO}_{\text {calcite }}+\mathrm{NaCl}=\mathrm{CaCl}^{+}+\mathrm{NaCO}_{3}^{-}
$$

Further discussion of the chemistry of saline brines can be found in Newton and Manning (2010).

\section{Experimental studies of cal-} cite solubility in $\mathrm{CO}_{2}-\mathrm{H}_{2} \mathrm{O}$. Miller (1952), Ellis (1959b), Sharp and Kennedy (1965), and Malinin and Kanukov (1972) showed that, at low fixed $P$ and $T$, calcite solubility in $\mathrm{H}_{2} \mathrm{O}$ increases to a maximum and then declines with increasing $X_{\mathrm{CO}_{2}}$. Fein and Walther (1987) extended these studies to $0.2 \mathrm{GPa}$, $550{ }^{\circ} \mathrm{C}$, and found similar behavior. At $0.2 \mathrm{GPa}$, calcite solubility reaches a maximum at $X_{\mathrm{CO}_{2}}=$ 0.025 to 0.05 and then decreases (Fig. 8). Fein and Walther suggested that this solubility behavior arises from the tradeoff between increasing formation of bicarbonate and decreasing $\mathrm{H}_{2} \mathrm{O}$ activity as $X_{\mathrm{CO}_{2}}$ increased.

\section{Thermodynamics of oxidized} carbon in dilute aqueous systems. Two fundamentally different approaches to treat oxidized dissolved carbon species have evolved in the literature, depending on the application. The first approach, which could be termed a component approach, is commonly used for the treatment of metamorphic fluids and fluids in the mantle (Anderson and Crerar 1993; Zhang and Duan 2009). It treats $\mathrm{CO}_{2}$ as a component for which the partial molal Gibbs free energy $\left(\bar{G}_{\mathrm{CO}_{2} ; P, T}\right)$ is expressed by

$$
\bar{G}_{\mathrm{CO}_{2} ; P, T}=\bar{G}_{\mathrm{CO}_{2} ; P=1.0, T}^{0}+R T \ln \chi_{\mathrm{CO}_{2} ; P, T} X_{\mathrm{CO}_{2} ; P, T} P_{\mathrm{CO}_{2} ; P, T}
$$

where the first term on the right-hand side represents the standard partial molal Gibbs energy of $\mathrm{CO}_{2}\left(\bar{G}_{\mathrm{CO}_{2} ; P=1.0, T}^{0}\right)$. The standard state is the hypothetical ideal gas at the temperature of interest and 1 atmosphere. The second term on the right-hand side represents the connection from the standard state to the real fluid. In this term, $\chi_{\mathrm{CO}_{2} ; P, T}$ represents the fugacity coefficient, $X_{\mathrm{CO}_{2} ; P, T}$ the mole fraction and $P_{\mathrm{CO}_{2} ; P, T}$ the partial pressure of $\mathrm{CO}_{2}$, all at the pressure and temperature of interest. 
This approach ignores the detailed speciation of the dissolved carbon dioxide. There is no concept of $\mathrm{pH}$ in the model. Advantages of this approach are that the first term on the right-hand side of Equation (9) can be easily calculated from experimental data and statistical mechanics, and that it permits consideration of the full compositional range along the $\mathrm{CO}_{2}-\mathrm{H}_{2} \mathrm{O}$ binary (see below). Most of the labor involved in this approach is associated with evaluating the second term on the right-hand side. Specifically, very intensive experimental and theoretical efforts are needed to derive the fugacity coefficients for pure fluids and mixtures of fluids (Jacobs and Kerrick 1981b; Kerrick and Jacobs 1981; Holland and Powell 1991; Zhang et al. 2007; Zhang and Duan 2009). Without any experimental data it is difficult to implement this approach.

The second approach could be called the speciation approach, commonly used in the aqueous geochemistry of hydrothermal fluids. Here, all known dissolved carbon species are treated explicitly and the dependence on $\mathrm{pH}$ and concentrations of other components can be evaluated. For example, for the dissolved carbonate ion, we treat the partial molal Gibbs free energy of formation of the ion $\left(\Delta \bar{G}_{f, \mathrm{CO}_{3}^{2-} ; P, T}^{0}\right)$ by defining

$$
\Delta \bar{G}_{f, \mathrm{CO}_{3}^{2-} ; P, T}=\Delta \bar{G}_{f, \mathrm{CO}_{3}^{2-} ; P_{r}, T_{r}}^{0}+R T \ln \gamma_{\mathrm{CO}_{3}^{2-} ; P, T} m_{\mathrm{CO}_{3}^{2-} ; P, T}
$$

where $\Delta \bar{G}_{f, \mathrm{CO}_{3}^{2-} ; P_{r}, T_{r}}^{0}$ represents the standard partial molal free energy of formation at reference pressure and temperature, and $\gamma_{\mathrm{CO}_{3}^{2-} ; P, T}$ and $m_{\mathrm{CO}_{3}^{2-} ; P, T}$ represent the activity coefficient and molality, respectively, of the aqueous carbonate ion. Here the standard state is the hypothetical 1.0 $\mathrm{M}$ solution referenced to infinite dilution at the temperature and pressure of interest. The advantage of this approach is that ions are treated explicitly, enabling $\mathrm{pH}$ variations to be analyzed as a result of interactions with silicate mineral assemblages that control activity ratios such as $a_{\mathrm{Ca}^{2+}} / a_{\mathrm{H}^{+}}^{2}$. Disadvantages of this approach are that only species whose existence is known can be included in the model, and its applicability is limited to $\mathrm{H}_{2} \mathrm{O}$-rich solutions and conditions where $\mathrm{H}_{2} \mathrm{O}$ solvent properties are well known.

The most difficult and uncertain aspect of evaluating Equation (10) is the calculation of the first term on the right-hand side: the standard Gibbs free energy of formation of the ion. Considerable effort has been expended in developing methods to calculate this term for many types of aqueous species including metal complexes and biomolecules (Shock and Helgeson 1988, 1990; Shock et al. 1989, 1997a, 1997b; Shock 1995; Amend and Helgeson 1997; Sverjensky et al. 1997; Plyasunov and Shock 2001; Richard 2001; Dick et al. 2006). In contrast, the second term on the right-hand side can be approximated-at least for water-rich fluidsby a variety of models, which can be used to evaluate the aqueous ion activity coefficients. Experimental and theoretical studies relevant to these two approaches are summarized below.

As an example of the species approach we focus on the aqueous $\mathrm{CO}_{3}{ }^{2-}$ ion. The standard Gibbs free energy of formation of the ion at elevated pressure and temperature can be calculated from

$$
\Delta \bar{G}_{f, \mathrm{CO}_{3}^{2-} ; P, T}^{0}=\Delta \bar{G}_{f, \mathrm{CO}_{3}^{2-} ; P_{r}, T_{r}}^{0}+f(P, T)+\omega_{\mathrm{CO}_{3}^{2-}}\left(\frac{1}{\varepsilon_{\mathrm{H}_{2} \mathrm{O}}}-1\right)
$$

where $\Delta \bar{G}_{f, \mathrm{CO}_{3}^{2-}: P, T}^{0}$ again represents the free energy at the reference pressure and temperature (Shock et al. 1997b). The function $f(P, T)$ is a complex function of equation-of-state coefficients of the carbonate ion associated with the non-solvation part of the Gibbs free energy change, and $\omega_{\mathrm{CO}_{3}^{2-}}$ represents the equation-of-state coefficient for the carbonate ion associated with the solvation part of the Gibbs free energy change, which also depends on the dielectric constant of pure water $\left(\varepsilon_{\mathrm{H}_{2} \mathrm{O}}\right)$. Equation-of-state coefficients have been developed for hundreds of aqueous species and are part of the data file for the programs SUPCRT92 (Johnson et al. 1992) and CHNOSZ (Dick et al. 2008). 
Equation (11) emphasizes that the dielectric constant at pressure and temperature is a critical parameter for evaluating the standard Gibbs energies of aqueous species at high pressures and temperatures. However, extensive sets of experimental values of $\varepsilon_{\mathrm{H}_{2} \mathrm{O}}$ have only been measured to about $0.5 \mathrm{GPa}$ and $550{ }^{\circ} \mathrm{C}$ (Heger et al. 1980). A synthesis of these values together with estimates from the Kirkwood equation (Pitzer 1983) is incorporated in SUPCRT92 which enables prediction to $0.5 \mathrm{GPa}$ and $1000{ }^{\circ} \mathrm{C}$ (Shock et al. 1992). A more recent synthesis, also based on the Kirkwood equation has been extrapolated to $1.0 \mathrm{GPa}$ and 1,200 K (Fernandez et al. 1997). The limitation of SUPCRT92 calculations to $0.5 \mathrm{GPa}$ has long been a severe roadblock to the application of quantitative aqueous geochemistry to deep crustal and mantle conditions. Methods for making calculations at higher pressures up to 3.0 GPa are summarized below.

Much progress has been made in recent years by extrapolating experimental solubilities and individual equilibrium constants to pressures substantially greater than the $0.5 \mathrm{GPa}$ limitation of SUPCRT92 (Manning 1994, 1998, 2004; Caciagli 2003; Dolejs and Manning 2010). Empirical extrapolations can be carried out by taking advantage of the approximate linearity of many equilibrium constants when plotted in terms of the $\log K$ versus the $\log \rho_{\mathrm{H}_{2} \mathrm{O}}$ at a given temperature, where $\rho_{\mathrm{H}_{2} \mathrm{O}}$ is the density of water. An example for the solubility product of calcite is shown in Figure 9. Extrapolation of equilibrium constants as in Figure 9, together with other aqueous phase equilibria involving dissolved oxidized carbon species enables prediction of solubility and aqueous speciation involving aqueous ions at elevated pressure and temperature without using Equations (10) and (11).

Evaluation of the aqueous ion activity coefficients in Equation (10) at pressures and temperatures to $0.5 \mathrm{GPa}$ and $550{ }^{\circ} \mathrm{C}$ is carried out using the extended Debye-Hückel equation for $\mathrm{NaCl}$-bearing fluids (Helgeson et al. 1981). For example, the activity coefficient of the carbonate ion is calculated according to

$$
\log \gamma_{\mathrm{CO}_{3}^{2-}}=-\frac{Z_{\mathrm{CO}_{3}^{2-}}^{2} A_{\gamma} \bar{I}^{0.5}}{a_{\mathrm{NaCl}}^{0} B_{\gamma} \bar{I}^{0.5}}+b_{\gamma, \mathrm{NaCl}} \bar{I}
$$

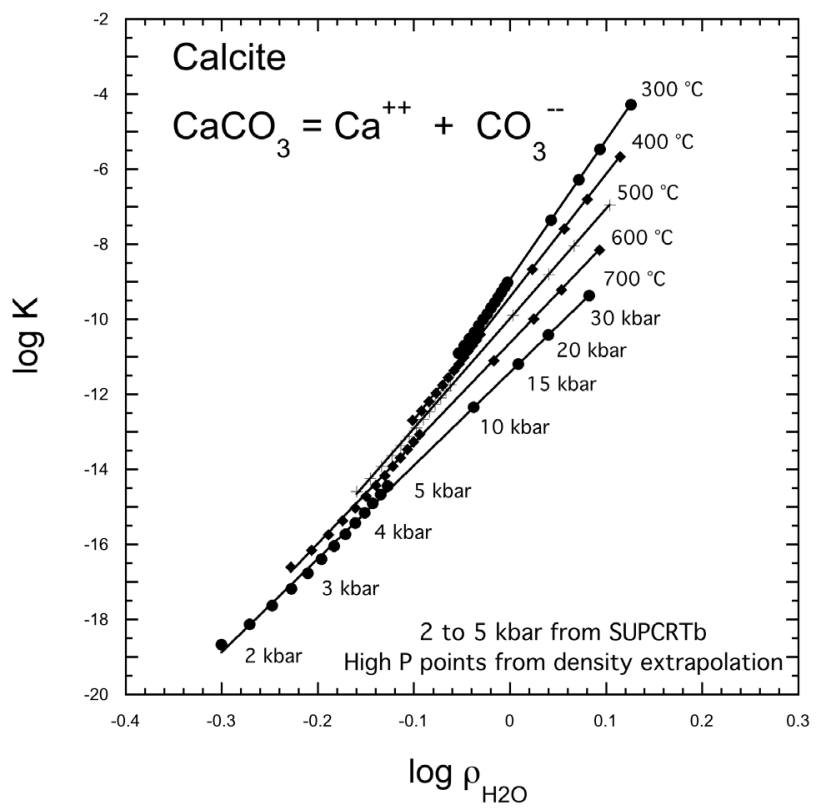

Figure 9. Predicted equilibrium constants for the solubility product of calcite. Values at $2-5 \mathrm{kbar}(1 \mathrm{kbar}=0.1 \mathrm{GPa})$ calculated from SUPCRT92 (Johnson et al. 1992); values at higher pressure linearly extrapolated. The solubility product is lower than calcite solubility in $\mathrm{H}_{2} \mathrm{O}$ due to speciation of carbon in the aqueous phase. 
where $Z$ refers to the charge on the carbonate ion $(-2), A_{\gamma}$ and $B_{\gamma}$ refer to Debye-Hückel coefficients that are properties of pure water (Helgeson and Kirkham 1974a,b); $a_{\mathrm{NaCl}}^{0}$ refers to the ion-size parameter for $\mathrm{NaCl}$ solutions, $I$ refers to the ionic strength, and $b_{\gamma, \mathrm{NaCl}}$ represents the extended term parameter for $\mathrm{NaCl}$ solutions. Using smoothed values of the dielectric constant from Helgeson and Kirkham (1974a), Franck et al. (1990), and Fernandez et al. (1997), it is possible to obtain estimates of $A_{\gamma}$ and $B_{\gamma}$ (Fig. 10). Values of the extended term parameter $b_{\gamma, \mathrm{NaCl}}$ are subject to substantial uncertainty at elevated pressures and temperatures, but can be
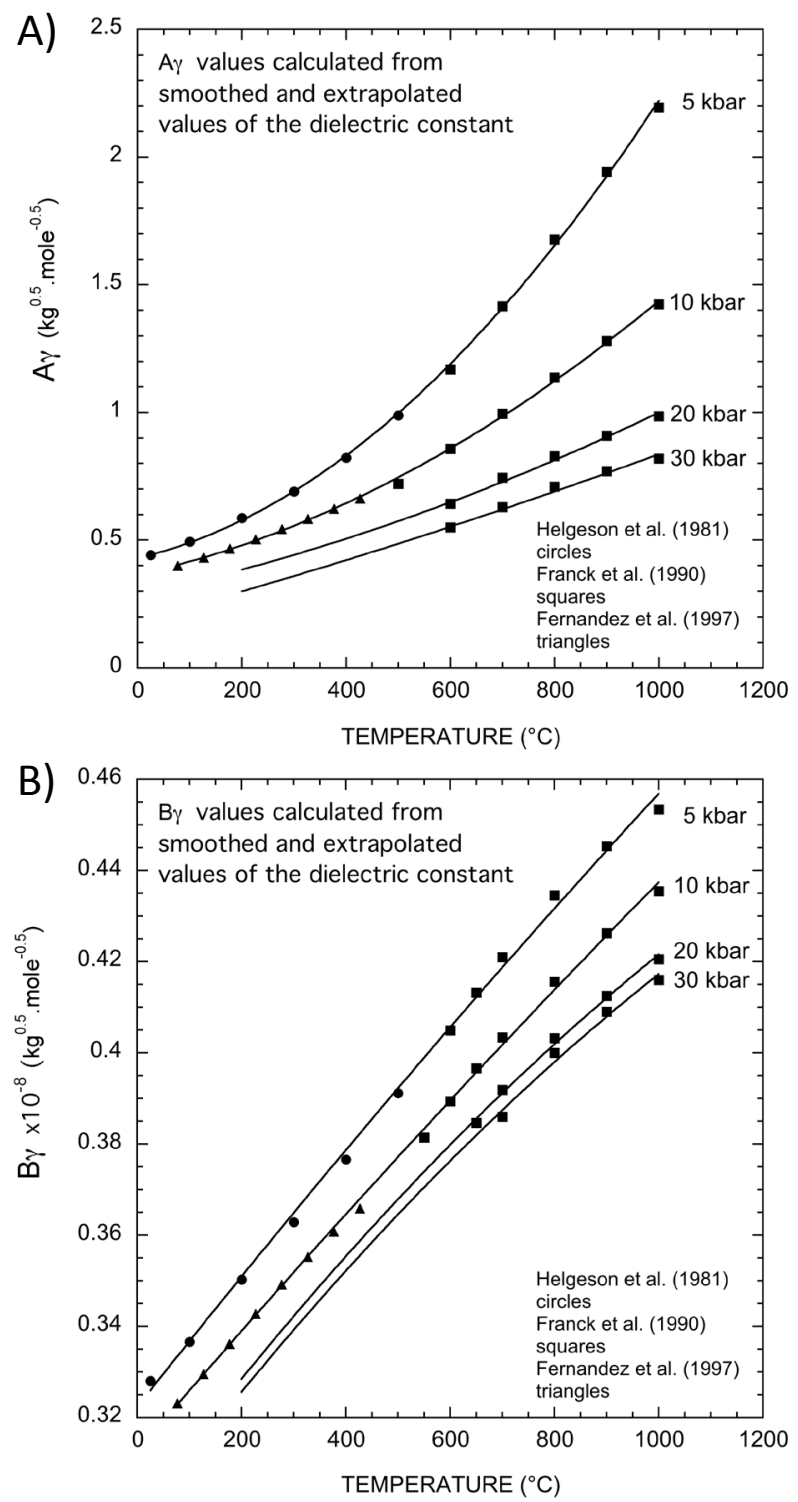

Figure 10. Predicted values of the Debye-Hückel parameters $A_{\gamma}$ and $B_{\gamma}$, based on estimates of the dielectric constant of water from Helgeson et al. (1974a, 1981), Franck et al. (1990) and Fernandez et al. (1997) $(1 \mathrm{kbar}=0.1 \mathrm{GPa})$. 
estimated from correlation with the density of water to give the preliminary estimates shown in Figure 11.

Taken together, equilibrium constants such as those shown in Figure 10 and Debye-Hückel parameters such as those shown in Figures 10 and 11 can be used to estimate the solubilities of carbonate minerals in water. As an example, the solubility of calcite is shown in Figure 12 at 500 ${ }^{\circ} \mathrm{C}$ as a function of pressure. The predicted solubility of calcite can be compared with a variety of published experimental studies (Walther 1986; Fein 1989; Caciagli 2003). It can be seen that the predicted curve agrees well with the data from Fein and Walther (1989), but is higher than the data from Walther and Long (1986), and is in agreement with the lowest solubilities reported by Caciagli and Manning (2003). The steep increase in solubility between 0.1 and 0.5 GPa noted by Caciagli and Manning (2003) tapers off to a much slower rate of increase with pressure approaching $3.0 \mathrm{Gpa}$ at $500{ }^{\circ} \mathrm{C}$. In this range of pressures, the predominant reaction controlling the solubility of calcite is given by

$$
\begin{aligned}
& \mathrm{CaCO}_{3}+\mathrm{H}_{2} \mathrm{O}=\mathrm{Ca}^{+2}+2 \mathrm{OH}^{-}+\mathrm{CO}_{2, \mathrm{aq}} \\
& \text { calcite }
\end{aligned}
$$

The calculated $\mathrm{pH}$ values vary from 7.8 at $0.1 \mathrm{GPa}$ to 5.4 at $3.0 \mathrm{GPa}$, yet less than $5 \%$ of the dissolved carbon is present as $\mathrm{HCO}_{3}{ }^{-}$and $\mathrm{CO}_{3}{ }^{2-}$ in the fluids.

It should be emphasized that the theoretical curve shown in Figure 12 is completely predicted based on the established standard Gibbs free energy of formation of calcite (Berman 1988), the estimated equilibrium constants for

$$
\mathrm{H}_{2} \mathrm{O}=\mathrm{H}^{+}+\mathrm{OH}^{-}
$$

and reactions (2), (3), and (13), extrapolated to elevated pressures as described above with the density model and the estimated aqueous ion activity coefficients discussed above. As noted above, the extrapolations for the $\log K$ values were based on SUPCRT92 predictions to $0.5 \mathrm{GPa}$ using published equations of state for aqueous $\mathrm{CO}_{2}, \mathrm{HCO}_{3}{ }^{-}$, and $\mathrm{CO}_{3}{ }^{2-}$ (Shock et al. 1989, 1997). However, the density extrapolation for the water dissociation reaction (Eqn. 13) was based on an independent summary of experimental values (Marshall and Franck 1981).

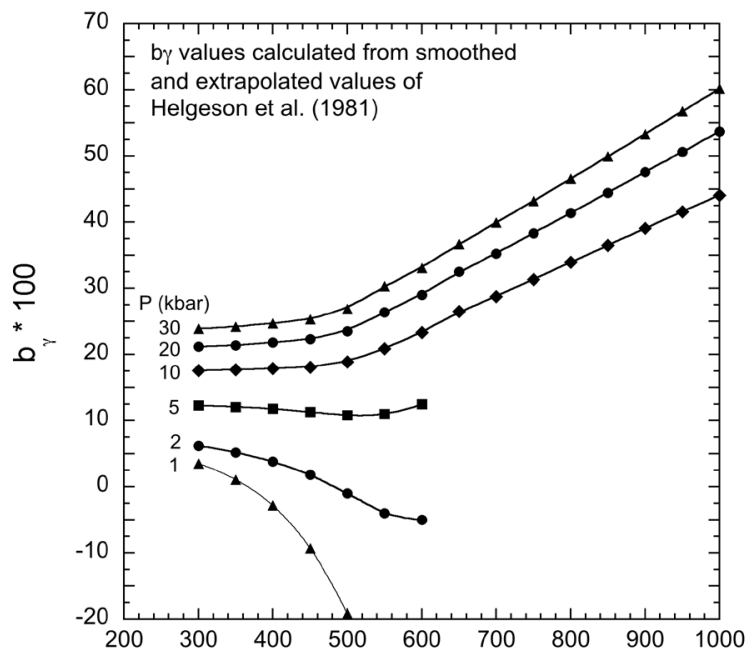

Figure 11. Predicted values of the extended term parameter $\left(b_{\gamma, \mathrm{NaCl}}\right)$ based on preliminary extrapolations of the values given in Helgeson et al. (1981) using empirical correlations with the density of water $(1 \mathrm{kbar}=0.1 \mathrm{GPa})$. 


\section{$\mathrm{CO}_{2}-\mathrm{H}_{2} \mathrm{O}$ mixing and miscibility}

Above a temperature of about $350{ }^{\circ} \mathrm{C}$ and pressures higher than the $\mathrm{H}_{2} \mathrm{O}$ liquid-vapor saturation curve, $\mathrm{H}_{2} \mathrm{O}$ and $\mathrm{CO}_{2}$ are fully miscible (Fig. 13). Full miscibility therefore occurs at most conditions relevant for studies of the deep carbon cycle-much of the crust and all of the mantle - and fluids may be much richer in oxidized carbon than in the more "dilute" systems discussed above. However, complexities arise in fluids with additional components. While there is a substantial literature devoted to the thermodynamic behavior of the binary $\mathrm{CO}_{2^{-}}$ $\mathrm{H}_{2} \mathrm{O}$ system, much remains to be done to improve our understanding of more compositionally relevant fluids expected in deep environments.

Experimental and theoretical constraints on the $\mathrm{CO}_{2}-\mathrm{H}_{2} \mathrm{O}$ binary. The mixing of $\mathrm{CO}_{2}$ and $\mathrm{H}_{2} \mathrm{O}$ is highly nonideal (Eqn. 9), so considerable effort has been dedicated to generating experimental and theoretical constraints for use in petrology. Experimental studies take two approaches. A variety of methods has been used to obtain direct measurement of volumes of mixing in homogeneous $\mathrm{CO}_{2}-\mathrm{H}_{2} \mathrm{O}$ fluids (Todheide and Franck 1963; Takenouchi and Kennedy 1964; Sterner and Bodnar 1991; Seitz and Blencoe 1999). Experimental challenges generally limit these studies to low pressure. Studies utilizing synthetic fluid inclusions hold promise for

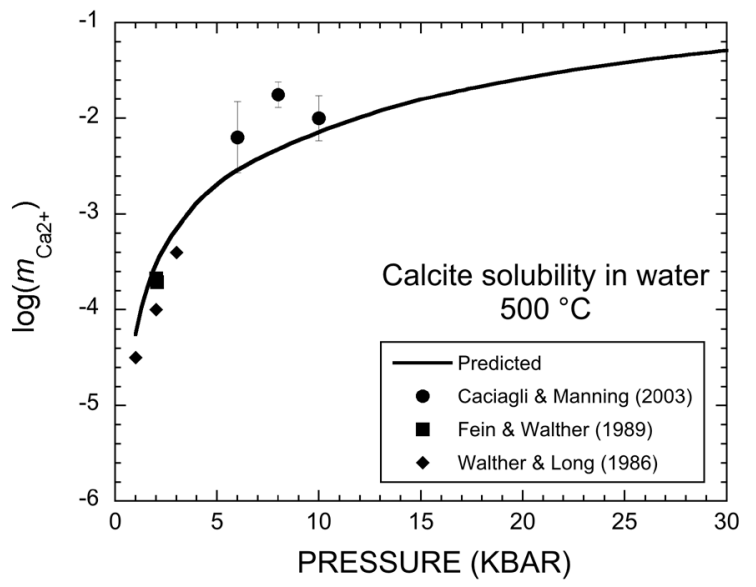

Figure 12. Predicted solubility of calcite in water as a function of pressure at $500{ }^{\circ} \mathrm{C}$. The calculations were carried out using equilibrium constants for carbon-bearing species extrapolated using the density of water and aqueous activity coefficients calculated using Equation (12) and the DebyeHückel parameters in Figures 10 and $11(1 \mathrm{kbar}=0.1 \mathrm{GPa})($ see text $)$.

Figure 13. Pressure-temperature diagram showing critical curves for $\mathrm{H}_{2} \mathrm{O}$ $\mathrm{CO}_{2}$ and $\mathrm{H}_{2} \mathrm{O}-\mathrm{CH}_{4}$ mixing, after Liebscher (2010). The boiling curve for $\mathrm{H}_{2} \mathrm{O}$ $\left(\mathrm{H}_{2} \mathrm{O} \mathrm{L}+\mathrm{V}\right)$ terminates at the critical point $\left(\mathrm{CP} \mathrm{H}_{2} \mathrm{O}\right)$. At pressure higher than $\mathrm{CP} \mathrm{H}_{2} \mathrm{O}$ and assuming equilibrium, the binary systems $\mathrm{H}_{2} \mathrm{O}-\mathrm{CO}_{2}$ and $\mathrm{H}_{2} \mathrm{O}-\mathrm{CH}_{4}$ exist as two phases at temperature lower than the critical curve, or as a single fluid phase at temperature higher than the critical curve. In the two-phase field, an $\mathrm{H}_{2} \mathrm{O}$-rich liquid coexists with a C-rich vapor. The composition of the fluid varies along each binary critical curve.

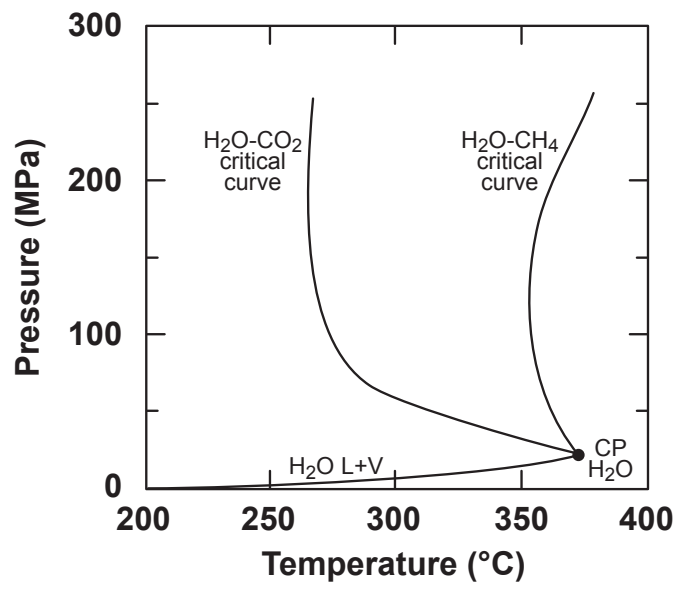


extending PVT measurements to higher pressures (e.g., Sterner and Bodnar 1991; Frost and Wood 1997). An alternative is study of displacement of mineral equilibria as a function of fluid composition in mixed volatile systems. Building on pioneering work by Greenwood, Metz, Skippen, and co-workers (e.g., Greenwood 1967; Metz and Trommsdorff 1968; Skippen 1971), a number of investigators have provided high-pressure constraints on the mixing properties of the $\mathrm{CO}_{2}-\mathrm{H}_{2} \mathrm{O}$ binary (Eggert and Kerrick 1981; Jacobs and Kerrick 1981a; Aranovich and Newton 1999). Theoretical approaches also offer promise (Brodholt and Wood 1993; Destrigneville et al. 1996).

The experimental data and theoretical results serve as constraints for equations of state of $\mathrm{CO}_{2}-\mathrm{H}_{2} \mathrm{O}$ fluid mixtures. The literature on this topic is so large that even its review papers are too numerous to list completely. Useful compilations, contributions and critiques can be found in Ferry and Baumgartner (1987), Duan et al. (1996), and Gottschalk (2007).

$\mathrm{CO}_{2}-\mathrm{H}_{2} \mathrm{O}$-NaCland other complex fluids. Addition of $\mathrm{NaCl}$ to $\mathrm{CO}_{2}-\mathrm{H}_{2} \mathrm{O}$ yields an extensive region of immiscibility in the ternary system (e.g., Heinrich 2007). Experimental studies in this system were reviewed by Liebscher (2007). Extension of low- $P$ experiments (Gehrig et al. 1979; Anovitz et al. 2004; Aranovich et al. 2010) to $0.5 \mathrm{GPa}$ and beyond (Kotelnikov and Kotelnikova 1990; Johnson 1991; Frantz et al. 1992; Joyce and Holloway 1993; Gibert et al. 1998; Shmulovich and Graham 1999, 2004) indicates the presence of a miscibility gap between low density $\mathrm{CO}_{2}-\mathrm{H}_{2} \mathrm{O}$ rich vapor and $\mathrm{NaCl}-\mathrm{H}_{2} \mathrm{O}$-rich brine at a wide range of crustal and mantle $P$ and $T$. Experimental studies on $\mathrm{CaCl}_{2}-\mathrm{CO}_{2}-\mathrm{H}_{2} \mathrm{O}$ yield similar results (Zhang and Frantz 1989; Shmulovich and Graham 2004). Equations of state for ternary system have been constructed based on experiment and theory (Bowers and Helgeson 1983a,b; Duan et al. 1995), allowing computation of simple phase equilibria involving one or two fluid phases.

Figure 14a shows an example of the isothermal, isobaric ternary at $0.9 \mathrm{GPa}$ and $800{ }^{\circ} \mathrm{C}$. A single, miscible fluid phase occurs in the $\mathrm{H}_{2} \mathrm{O}$-rich portion of the system. Phase separation
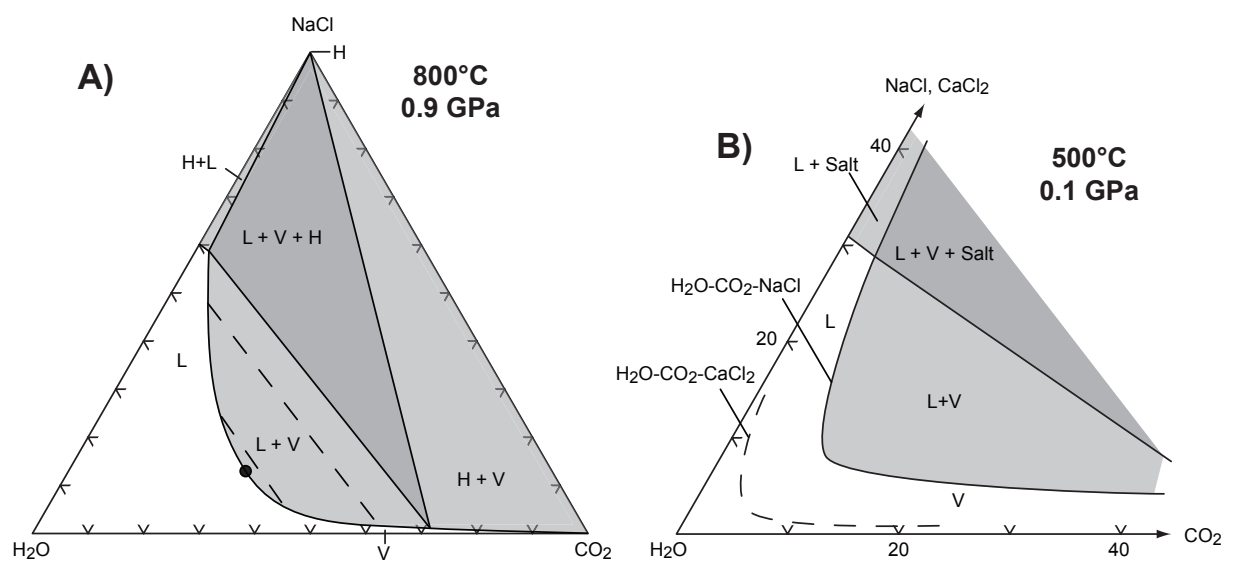

Figure 14. (A) Phase relations in the system $\mathrm{H}_{2} \mathrm{O}-\mathrm{CO}_{2}-\mathrm{NaCl}$ at $0.9 \mathrm{GPa}, 800{ }^{\circ} \mathrm{C}$ (Shmulovich and $\mathrm{Graham}$ 1999), in mol\%. Abbreviations: H, halite, L, liquid, V, vapor. The unshaded region marks stability of a single fluid phase, which varies continuously from liquid like (L) to vapor-like (V). Light shading denotes fields where two phases coexist at equilibrium: liquid-vapor $(\mathrm{L}+\mathrm{V})$, halite-liquid $(\mathrm{H}+\mathrm{L})$, and halite-vapor $(\mathrm{H}+\mathrm{V})$; selected coexisting compositions are indicated by dashed tie lines in the $\mathrm{L}+\mathrm{V}$ field. Dark shading denotes the liquid-vapor-halite $(\mathrm{L}+\mathrm{V}+\mathrm{H})$ field, in which the compositions of all three phases are fixed at the apices. (B) Comparison of relations in the systems $\mathrm{H}_{2} \mathrm{O}-\mathrm{CO}_{2}-\mathrm{NaCl}$ (solid lines, shading as in A) and $\mathrm{H}_{2} \mathrm{O}-\mathrm{CO}_{2}-\mathrm{CaCl}_{2}$ (dashed line) at $0.1 \mathrm{GPa}, 500{ }^{\circ} \mathrm{C}$ (Liebscher 2010). The two-phase field is larger for $\mathrm{CaCl}_{2}$ than for $\mathrm{NaCl}$. 
occurs at $<65 \mathrm{~mol} \% \mathrm{H}_{2} \mathrm{O}$, yielding an $\mathrm{NaCl}$-rich brine and a $\mathrm{CO}_{2}$-rich vapor. At these conditions, the brine phase attains halite saturation at $\sim 60 \mathrm{~mol} \% \mathrm{NaCl}$, whereas halite saturates in the vapor phase at only $\sim 1 \mathrm{~mol} \% \mathrm{NaCl}$ in fluids with $>72 \mathrm{~mol} \% \mathrm{CO}_{2}$. As illustrated in Figure 14b, replacement of $\mathrm{NaCl}$ by $\mathrm{CaCl}_{2}$ significantly expands the miscibility gap, all else equal.

Variations in the topology of the ternary system are illustrated in Figure 15, which shows that the miscibility gap is expected to persist for a wide range of crustal and mantle conditions, even for low-salinity $\mathrm{CO}_{2}-\mathrm{H}_{2} \mathrm{O}$ fluids. Newton and Manning (2002) hypothesized that, in the presence of calcite, $\mathrm{H}_{2} \mathrm{O}-\mathrm{NaCl}$ fluids may coexist with a hydrous, saline $\mathrm{CaCO}_{3}$ liquid at 800$1000{ }^{\circ} \mathrm{C}, 1.0 \mathrm{GPa}$ (Fig. 16). In general, extensive immiscibility in the $\mathrm{NaCl}-\mathrm{CO}_{2}-\mathrm{H}_{2} \mathrm{O}$ ternary system has fundamental importance for carbon transport in the crust and mantle. It requires that, in relatively $\mathrm{H}_{2} \mathrm{O}$-poor systems, $\mathrm{CO}_{2}$ is largely partitioned into a low-density vapor phase that may move separately from a dense, saline brine (Touret 1985; Skippen and Trommsdorff 1986; Trommsdorff and Skippen 1986; Newton et al. 1998; Heinrich et al. 2004).

Shmulovich et al. (2006) reported experimental data and a model for quartz solubility in $\mathrm{CO}_{2}-\mathrm{H}_{2} \mathrm{O}$ fluids containing different salts. However, there is currently insufficient data to constrain models that include the properties of ternary fluids in this system and ionic species. Though preliminary models have been constructed (e.g., Duan et al. 1995), more accurate and complete data and models are needed for treating complex reactive flow problems in crustal and mantle settings.

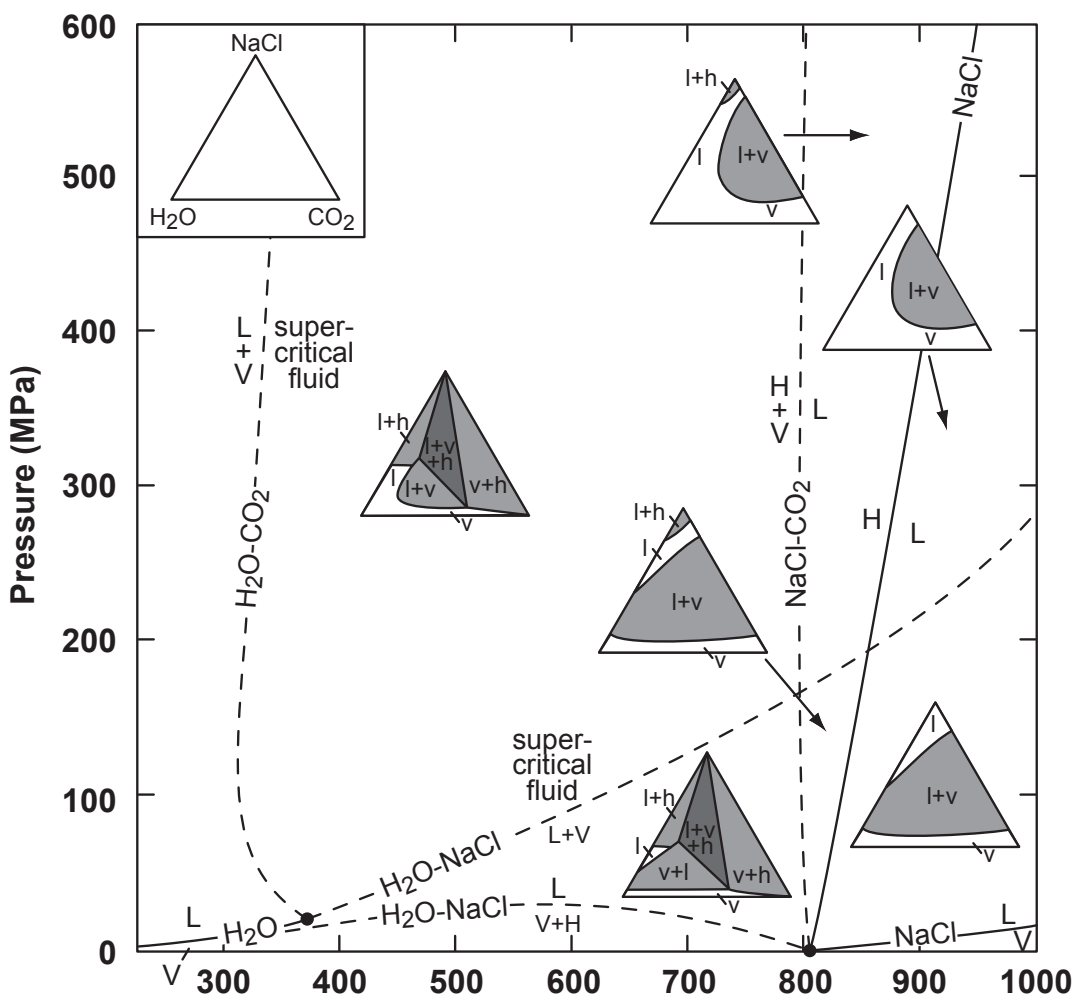

Figure 15. Variation in phase relations in the system $\mathrm{H}_{2} \mathrm{O}-\mathrm{CO}_{2}-\mathrm{NaCl}$ with pressure and temperature, after Heinrich et al. (2004). Inset shows apices of the ternary compositional space. Abbreviations: L, liquid; V, vapor; H, halite. Shading as in Figure 14. Tie-lines omitted for clarity. 


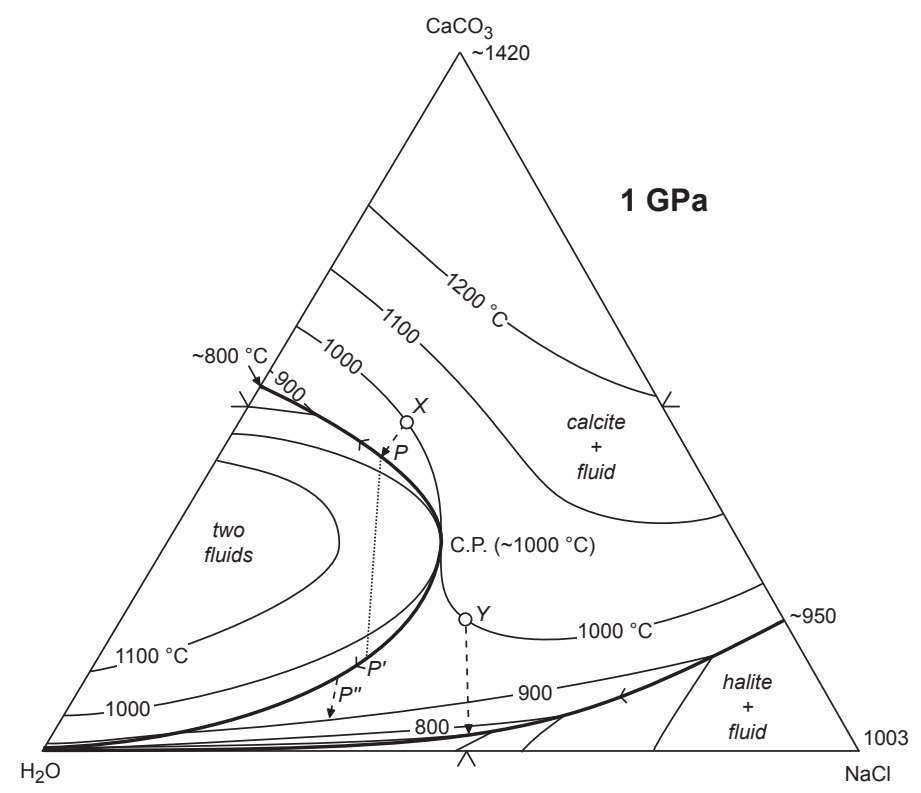

Figure 16. Semi-quantitative phase relations in the pseudo-ternary system $\mathrm{CaCO}_{3}-\mathrm{NaCl}-\mathrm{H}_{2} \mathrm{O}$ at $1 \mathrm{GPa}$ (in mol\%, after Newton and Manning 2002a). Newton and Manning hypothesized critical mixing between a hydrous, $\mathrm{NaCl}$-bearing carbonate liquid and $\mathrm{CaCO}_{3}$-rich brine at $\sim 1000{ }^{\circ} \mathrm{C}$ and $30 \mathrm{~mol} \% \mathrm{NaCl}, 25 \mathrm{~mol} \%$ $\mathrm{CaCO}_{3}(\mathrm{CP})$. A hydrous carbonate liquid in equilibrium with calcite at $1000{ }^{\circ} \mathrm{C}$ (composition $X$ ) will, upon cooling to $950{ }^{\circ} \mathrm{C}$ (point $P$ ), exsolve a concentrated salt solution (point $P^{\prime}$ ). Both fluids will crystallize calcite upon further cooling over a narrow temperature interval. At $P^{\prime \prime}$, only the $\mathrm{CaCO}_{3}$-rich brine phase remains, and deposits most of solute $\mathrm{CaCO}_{3}$ in cooling only $200{ }^{\circ} \mathrm{C}$ further. A calcite-saturated fluid that contains more $\mathrm{NaCl}$ (composition $Y$ ), but cooling from the same starting temperature of $1000{ }^{\circ} \mathrm{C}$, will avoid the two-fluid region and deposit nearly all of its substantial dissolved carbonate in isobaric cooling past $800{ }^{\circ} \mathrm{C}$.

It is generally assumed that non-polar molecules such as $\mathrm{CO}_{2}$ are poor solvents. However, it has been hypothesized that $\mathrm{CO}_{2}$-rich fluids are responsible for element metasomatism in several geologic contexts. For example, petrologic observations of some granulites require a fluid phase with low $\mathrm{H}_{2} \mathrm{O}$ activity that is capable of dissolving and redistributing important major and trace elements. Newton et al. (1980) argued that a silicate melt could not explain observations, and proposed a $\mathrm{CO}_{2}$-rich fluid instead. Although supported by evidence from $\mathrm{CO}_{2}$-rich fluid inclusions, petrologic considerations were problematic (Lamb and Valley 1987; Yardley and Valley 1997). The requirement that such a fluid was responsible for metasomatic transfer of presumed low-solubility elements such as alkalis and Th poses further challenges. Similar proposals have been made for REE and other element metasomatism in mantle xenoliths (Berkesi et al. 2012).

The immiscibility between brine and vapor in the $\mathrm{H}_{2} \mathrm{O}-\mathrm{CO}_{2}-\mathrm{NaCl}$ system even at very high $P$ and $T$ potentially solves this conundrum (Touret 1985; Newton et al. 1998; Newton and Manning 2010). In this hypothesis, metasomatism takes place in the presence of a two-phase fluid. The $\mathrm{CO}_{2}$-rich vapor phase has wetting properties that lead to its selective entrapment as fluid inclusions, while the brine phase is a powerful solvent responsible for observed metasomatism (Gibert et al. 1998). Both phases contain $\mathrm{CO}_{2}$, but partitioning between the phases differs depending on $P, T$, and composition. Such two-phase systems may be more important in crustal metamorphism than has previously been appreciated.

Mineral solubility and solute structure in $\mathrm{CO}_{2}-\mathrm{H}_{2} \mathrm{O}$ fluids. The presence of $\mathrm{CO}_{2}$ strongly influences mineral solubility and material transport by crustal and mantle aqueous fluids 
(Walther and Helgeson 1980). Because $\mathrm{CO}_{2}$ is non-polar (Fig. 1), its addition to $\mathrm{H}_{2} \mathrm{O}$ lowers the solvent dielectric constant at constant $P$ and $T$ (Walther and Schott 1988; Walther 1992), indicating that dilution of $\mathrm{H}_{2} \mathrm{O}$ by $\mathrm{CO}_{2}$ reduces the number of $\mathrm{H}_{2} \mathrm{O}$ molecules that solvate solutes dissolved in the fluid.

The disruption of ion hydration by $\mathrm{CO}_{2}$ in high $P$ - $T$ fluids was studied by Evans et al. (2009) using EXAFS on $\mathrm{RbBr}-\mathrm{H}_{2} \mathrm{O}-\mathrm{CO}_{2}$ fluids to $579{ }^{\circ} \mathrm{C}$ and $0.26 \mathrm{GPa}$. The fluids were trapped as synthetic fluid inclusions in corundum. In $\mathrm{CO}_{2}$-free solutions, the number of nearest neighbor oxygen atoms (in hydrating $\mathrm{H}_{2} \mathrm{O}$ molecules) decreased from $6 \pm 0.6$ to $1.4 \pm 0.1$ as $T$ increased from 20 to $534{ }^{\circ} \mathrm{C}$, and $P$ to $\sim 0.3 \mathrm{GPa}$. At $X_{\mathrm{CO}_{2}}=0.08$, Evans et al. (2009) infer decreases of 16 and $22 \%$ in the number of nearest-neighbor oxygen atoms at 312 and $445{ }^{\circ} \mathrm{C}$, respectively. This decrease suggests that $\mathrm{CO}_{2}$ addition leads to a reduced extent of ion hydration.

In their study of calcite solubility in $\mathrm{H}_{2} \mathrm{O}-\mathrm{CO}_{2}$ fluids, Fein and Walther (1987) found that at constant pressure and temperature, calcite solubility initially increases with increasing $X_{\mathrm{CO}_{2}}$ (Fig. 8). It reaches a maximum at $X_{\mathrm{CO}_{2}}=0.025$ to 0.05 and then decreases. Taking the calcite dissolution reaction to be

$$
\underset{\text { calcite }}{\mathrm{CaCO}_{3}}+2 \mathrm{H}^{+}=\mathrm{Ca}^{+2}+\mathrm{CO}_{2, \mathrm{aq}}+\mathrm{H}_{2} \mathrm{O}
$$

they inferred that the initial isothermal, isobaric solubility increase is due to reaction (2) progressing to the right. Although $\mathrm{H}_{2} \mathrm{O}$ activity declines with increasing $\mathrm{CO}_{2}$, the rise in $\mathrm{CO}_{2}$ evidently counters the drop in $\mathrm{H}_{2} \mathrm{O}$ activity (Eqn. 9). Fein and Walther (1987) suggested that the decline in calcite solubility is due to diminished extent of hydration of $\mathrm{Ca}^{+2}$ in solution.

Similar effects lead to a decrease in quartz solubility with increasing $X_{\mathrm{CO}_{2}}$. Solute silica does not form complexes with $\mathrm{CO}_{2}$, so changes in $\mathrm{H}_{2} \mathrm{O}$ activity are chiefly responsible for solubility variations with $X_{\mathrm{CO}_{2}}$ at a given $P$ and $T$. Walther and Orville (1983) suggested that $\mathrm{H}_{2} \mathrm{O}$ solvation of dissolved silica could be assessed by writing the quartz dissolution reaction as:

$$
\underset{\text { quartz }}{\mathrm{SiO}_{2}}+n \mathrm{H}_{2} \mathrm{O}=\underset{\text { solute complex }}{\mathrm{Si}(\mathrm{OH})_{4} \cdot(n-2) \mathrm{H}_{2} \mathrm{O}}
$$

The equation includes two moles of $\mathrm{H}_{2} \mathrm{O}$ as hydroxyl and $n-2$ moles of molecular, solvation $\mathrm{H}_{2} \mathrm{O}$ per mole of solute silicon. At constant $P$ and $T$, the number of $\mathrm{H}_{2} \mathrm{O}$ of solvation can be determined from quartz solubility data by the relation $n=d \log a_{\mathrm{Si}(\mathrm{OH})_{4} \cdot(n-2) \mathrm{H}_{2} \mathrm{O}} / d \log a_{\mathrm{H}_{2} \mathrm{O}}$. Early work lacked sufficient precision to derive the silica hydration state. Walther and Orville (1983) concluded that, assuming all silica dissolved as monomeric $\mathrm{Si}(\mathrm{OH})_{4}, n \approx 4$ (i.e., two molecular $\mathrm{H}_{2} \mathrm{O}$ of solvation) for many conditions, though uncertainties in $n$ were at least \pm 1 . Later studies yielded $n$ of 3.5 or 2 (Shmulovich et al. 2006; Akinfiev and Diamond 2009), or suggested that $n$ decreases with increasing $X_{\mathrm{CO}_{2}}$ at constant $P$ and $T$ (Newton and Manning 2000; Shmulovich et al. 2001).

Improved accuracy of this approach has been attained by taking advantage of new and more precise equations of state for $\mathrm{H}_{2} \mathrm{O}-\mathrm{CO}_{2}$ fluids (e.g., Aranovich and Newton 1999) and by accounting explicitly for aqueous silica polymerization (e.g., Zotov and Keppler 2000, 2002; Newton and Manning 2002b, 2003). Newton and Manning (2009) determined quartz solubility in $\mathrm{H}_{2} \mathrm{O}-\mathrm{CO}_{2}$ fluids at $800{ }^{\circ} \mathrm{C}$ and $1.0 \mathrm{GPa}$. Using experimentally constrained models of $\mathrm{H}_{2} \mathrm{O}$ activity and mixing of silica monomers and dimers, they determined that $n=4.0$ for their experiments and all previous high-quality data at different $P$ and $T$. They also obtained $n=7.0$ for silica dimers. These results indicate that, regardless of silica species, there are two solvating $\mathrm{H}_{2} \mathrm{O}$ molecules per $\mathrm{Si}$ in $\mathrm{H}_{2} \mathrm{O}-\mathrm{CO}_{2}$ fluids for a large range of crustal metasomatic processes. This result is somewhat surprising because it implies that the hydration state of aqueous silica does not change over a wide range of $X_{\mathrm{CO}_{2}}$. Evidently, within the limits of $X_{\mathrm{CO}_{2}}$ studied so far, the decline in silica solubility with increasing $\mathrm{CO}_{2}$ concentration means that there is always 
sufficient molecular $\mathrm{H}_{2} \mathrm{O}$ to supply the two $\mathrm{H}_{2} \mathrm{O}$ molecules associated with each dissolved $\mathrm{Si}$. The simple model for silica solubility in mixed $\mathrm{H}_{2} \mathrm{O}-\mathrm{CO}_{2}$ fluids aids study of crustal mass transfer (e.g., Ferry et al. 2011).

\section{REDUCED CARBON IN AQUEOUS FLUIDS AT HIGH $P$ AND $T$}

\section{$\mathrm{CH}_{4}$ and $\mathrm{CO}$ solubility in $\mathrm{H}_{2} \mathrm{O}$}

Gas solubilities in $\mathrm{H}_{2} \mathrm{O}$ generally decrease with rising temperature, but this is only true up to a certain temperature along the vapor-liquid saturation (boiling) curve for $\mathrm{H}_{2} \mathrm{O}$. Solubility minima vary among gases (Shock et al. 1989; Shock and McKinnon 1993; Plyasunov and Shock 2001). In the case of methane, the solubility minimum occurs at about $100{ }^{\circ} \mathrm{C}$ as shown in Figure 17. It can also be seen in Figure 17 that there is increasing experimental disagreement in the solubility of methane with increasing temperature, and the scatter seems to maximize at higher temperatures. The curve in Figure 17 is calculated with thermodynamic data and revised HKF equation-of-state parameters from Plyasunov and Shock (2001), who also used experimental high-temperature enthalpy of solution data and partial molal heat capacity data for $\mathrm{CH}_{4, \mathrm{aq}}$ in their regression procedure. Note that the calculated equilibrium constant for methane dissolution is an order of magnitude less negative at $300{ }^{\circ} \mathrm{C}$ than at the solubility minimum at $100{ }^{\circ} \mathrm{C}$, suggesting that significant amounts of methane can be lost from solution in cooling portions of hydrothermal systems.

Carbon monoxide is similar in solubility to $\mathrm{CH}_{4}$, as indicated by the curves in Figure 18, and both gases are considerably less soluble than $\mathrm{CO}_{2}$. Note that the minimum $\log K$ for the $\mathrm{CO}$ dissolution reaction is a little lower in temperature than that for $\mathrm{CH}_{4}$, but that both minima are at considerably lower temperatures than that for $\mathrm{CO}_{2}$, which occurs at about $175^{\circ} \mathrm{C}$. Although the

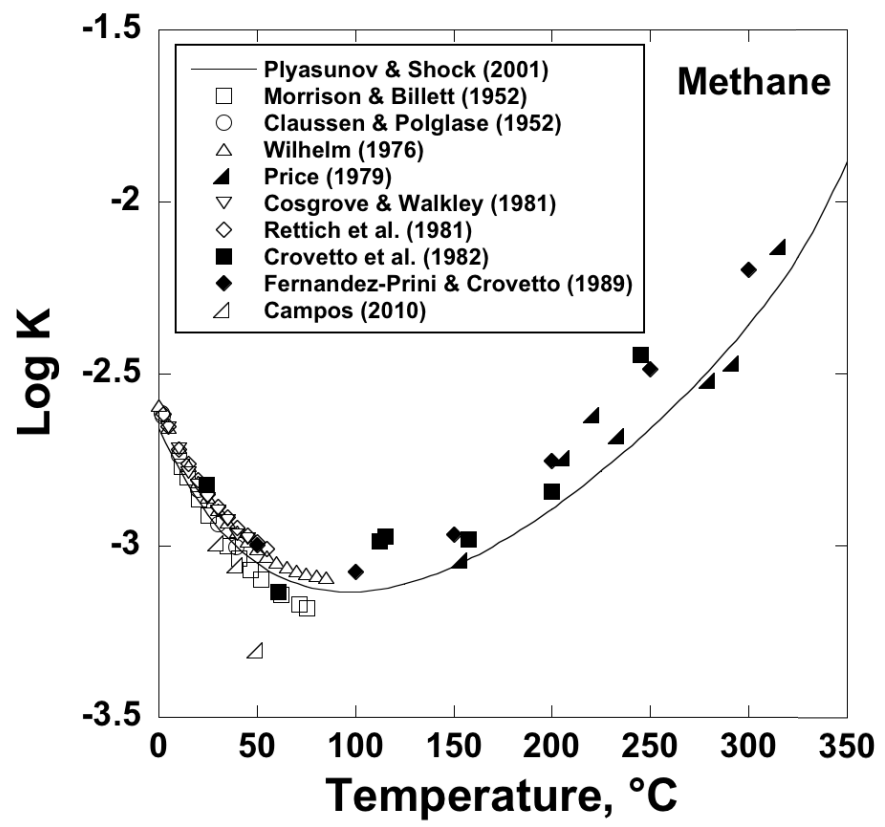

Figure 17. Experimental data (symbols) and calculated (curve) values for the equilibrium constant for the reaction $\mathrm{CH}_{4, \mathrm{~g}}=\mathrm{CH}_{4, \mathrm{aq}}$ along the $\mathrm{H}_{2} \mathrm{O}$ boiling curve. 


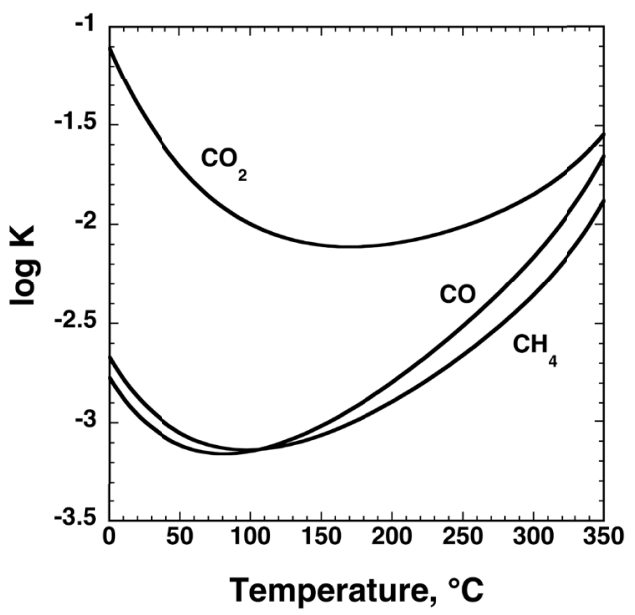

Figure 18. Equilibrium constants for dissolution of $\mathrm{CO}_{2}, \mathrm{CO}$, and $\mathrm{CH}_{4}$ in water along the $\mathrm{H}_{2} \mathrm{O}$ boiling curve. The curve for $\mathrm{CH}_{4}$ is the same as that shown in Figure 17, and the curves for $\mathrm{CO}_{2}$ and $\mathrm{CO}$ are similarly constrained by experimental data (Shock et al. 1989; Shock and McKinnon 1993). At similar fugacities, $\mathrm{CO}$ and $\mathrm{CH}_{4}$ would exhibit similar solubilities, which would be lower than the corresponding solubility of $\mathrm{CO}_{2}$.

curves differ by about $1.5 \log$ units at $0{ }^{\circ} \mathrm{C}$, they tend to converge with increasing temperature and are within $0.7 \log$ units of one another at $350{ }^{\circ} \mathrm{C}$. As a result, there are highly variable consequences for exsolution of gases during cooling of hydrothermal fluids.

As with $\mathrm{CO}_{2}, \mathrm{CH}_{4}$ and $\mathrm{CO}$ become fully miscible with $\mathrm{H}_{2} \mathrm{O}$ at $T$ greater than about $350{ }^{\circ} \mathrm{C}$ and modest pressure (Fig. 13). Thus, in most crustal and mantle contexts, binary fluids are stable as a single phase for all compositions. Numerous equations of state based on experiment and theory have been derived to describe the behavior of these fluids. Gottschalk (2007) provides a recent review of the topic.

Further similarities between $\mathrm{CH}_{4}-\mathrm{H}_{2} \mathrm{O}$ and $\mathrm{CO}_{2}-\mathrm{H}_{2} \mathrm{O}$ (and likely $\mathrm{CO}-\mathrm{H}_{2} \mathrm{O}$ as well) can be found in the role played by the addition of $\mathrm{NaCl}$. As in the $\mathrm{CO}_{2}-\mathrm{H}_{2} \mathrm{O}$ system discussed above, addition of $\mathrm{NaCl}$ leads to unmixing into two fluid phases, a $\mathrm{H}_{2} \mathrm{O}$-rich brine, and a $\mathrm{CH}_{4}$-rich vapor (Fig. 19). Generally, it can be expected that the similarity in $\mathrm{CH}_{4}-\mathrm{H}_{2} \mathrm{O}$ and $\mathrm{CO}_{2}-\mathrm{H}_{2} \mathrm{O}$ mixing properties should lead to very similar geochemical behavior of the molecular carbon species in aqueous solutions. For example, it can be anticipated that the effect of $\mathrm{CH}_{4}$ on quartz solubility is similar to that of $\mathrm{CO}_{2}$ as described by Newton and Manning (2009), all else equal.

\section{Kinetic inhibition of $\mathrm{CH}_{4}$ formation}

In many crustal fluids, coexisting $\mathrm{CO}_{2}$ and $\mathrm{CH}_{4}$ are not in equilibrium with each other (e.g., Janecky and Seyfried 1986; Shock 1988, 1990; Charlou et al. 1998, 2000; McCollom and Seewald 2001). Disequilibrium is most pronounced at temperatures below about $500{ }^{\circ} \mathrm{C}$ (Shock 1990, 1992), which are relevant to low-grade metamorphism, hydrothermal systems, sedimentary basins, and subduction zones. The underlying reasons for this disequilibrium state lie in the difficulty of breaking bonds and transferring the eight electrons required for $\mathrm{CO}_{2}$ and $\mathrm{CH}_{4}$ to react reversibly. Consequently, stable equilibrium between $\mathrm{CO}_{2}$ and $\mathrm{CH}_{4}$ is in many cases attained only at high $P$ and $T$. In many hydrothermal systems, and throughout sedimentary basins, $\mathrm{CH}_{4}$ is so slow to form that it persists in concentrations that are far from equilibrium with redox conditions determined by coexisting mineral assemblages.

As shown in Figure 20, the kinetic inhibition of $\mathrm{CO}_{2}-\mathrm{CH}_{4}$ equilibration produces a "window of opportunity" for metastable persistence of a wide array of aqueous organic compounds at conditions where C-O-H fluids at equilibrium would otherwise consist almost entirely of $\mathrm{CO}_{2}$, $\mathrm{CH}_{4}, \mathrm{H}_{2} \mathrm{O}$, and $\mathrm{H}_{2}$. Although organic compounds are less stable than $\mathrm{CO}_{2}$ or $\mathrm{CH}_{4}$ depending on the prevailing oxidation-reduction conditions, the sluggish kinetics allow them to persist 


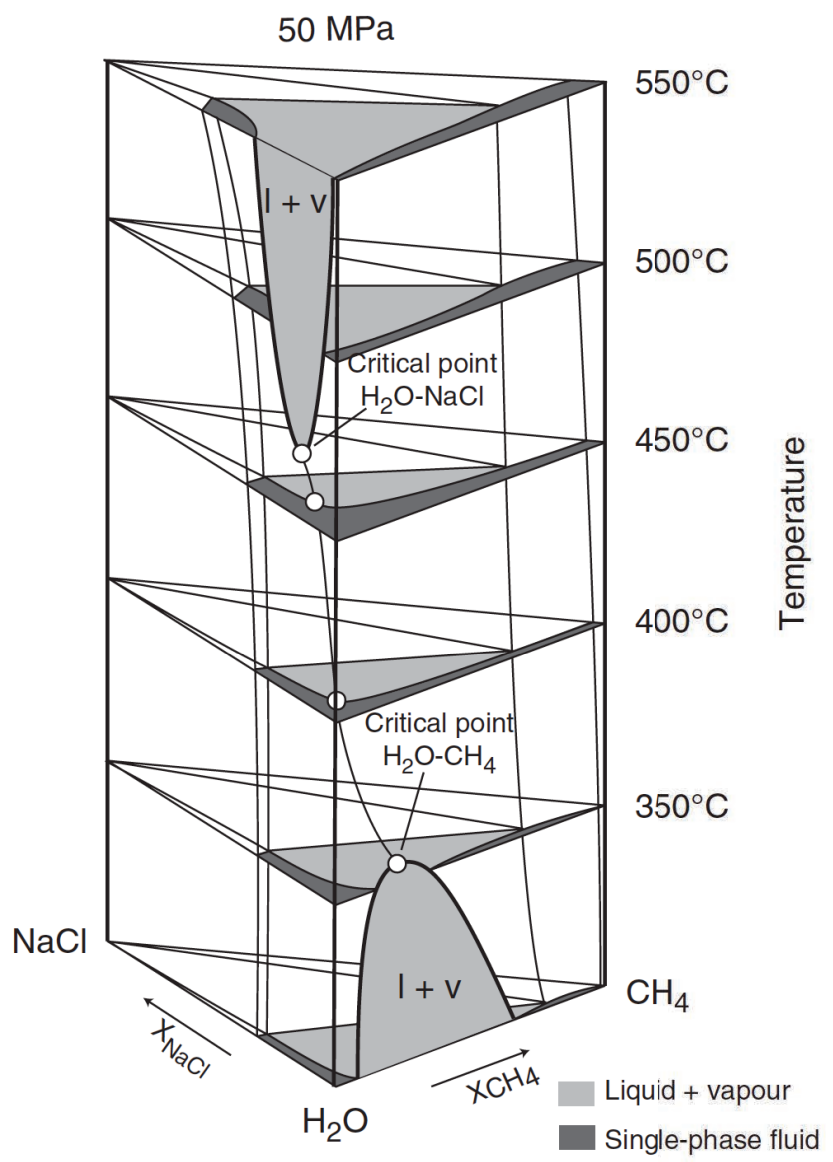

Figure 19. Phase relations in the systems $\mathrm{H}_{2} \mathrm{O}-\mathrm{CH}_{4}-\mathrm{NaCl}$ at $50 \mathrm{MPa}$ (Liebscher 2010). A two-phase field in which $\mathrm{NaCl}$-rich aqueous brine coexists with $\mathrm{CH}_{4}$-rich vapor is persists over a wide range of temperature. [Reproduced from Liebscher (2010) Geofluids, Vol. 10, p. 3-19, by permission of John Wiley \& Sons.]

within this window for millions to billions of years. This metastability is why petroleum, coal, kerogen, bitumen, and other forms of organic matter persevere in sedimentary and lowgrade metamorphic rocks, and why organic compounds are often encountered in hydrothermal systems. Slow reaction rates also help explain why there are organic compounds present in carbonaceous meteorites billions of years after their formation through complex processes in the condensing solar nebula and on the parent bodies of the meteorites. In fact, metastable organic compounds are relatively abundant throughout the Solar System, especially in the outer reaches populated by icy satellites and comets, which appear to have extensive inventories of organic compounds.

Even though organic compounds persist in metastable states, they continue to react in response to thermodynamic driving forces. In many cases, reactions among organic compounds reach metastable equilibrium states, in which the organic compounds attain ratios consistent with equilibrium constants for reactions written among them. These metastable states were first recognized in data from natural systems (Shock 1988, 1989, 1994; Helgeson et al. 1993), which led to experimental tests first with hydrocarbons (Seewald 1994) and then with organic 


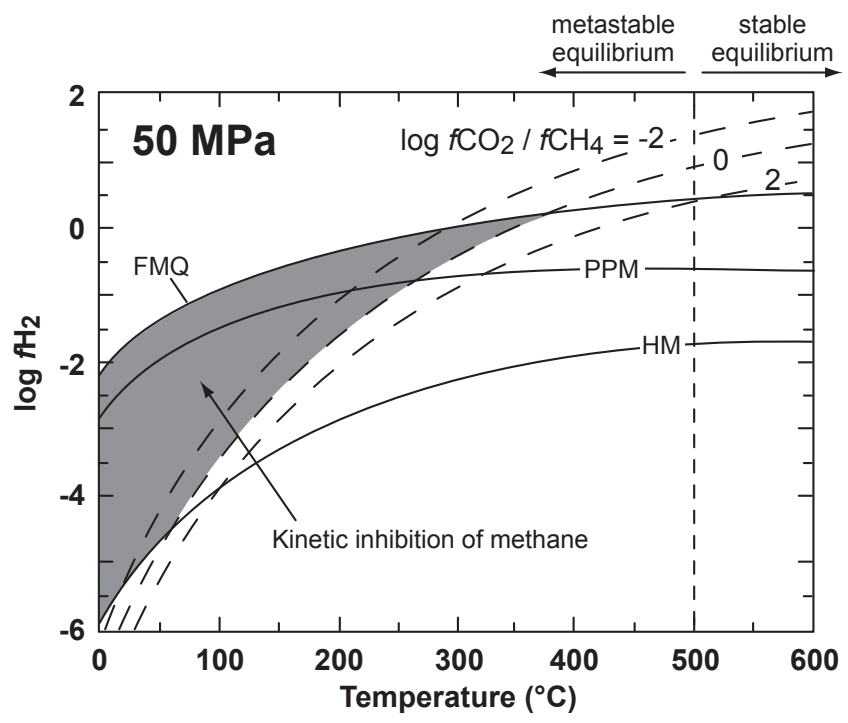

Figure 20. Fugacity of $\mathrm{H}_{2}$ versus temperature at $50 \mathrm{MPa}$. Solid curves show values of $\log f_{\mathrm{H}_{2}}$ buffered by the mineral equilibria fayalite-quartz-magnetite (FMQ), pyrite-pyrrhotite-magneite (PPM), and hematitemagnetite (HM). Dashed curves correspond to contours of $\log \left(f_{\mathrm{CO}_{2}} / f_{\mathrm{CH}_{4}}\right)$ equal to 2,0 , and -2 . Dotted vertical line at $500{ }^{\circ} \mathrm{C}$ demarcates hypothetical boundary between stable equilibrium in the $\mathrm{C}$-H-O system $\left(T>500^{\circ} \mathrm{C}\right)$, and kinetic inhibition of $\mathrm{CO}_{2}$ reduction to $\mathrm{CH}_{4}$ where metastable equilibrium states between $\mathrm{CO}_{2}$ and aqueous organic compounds may prevail $\left(T<500{ }^{\circ} \mathrm{C}\right)$. Shaded area corresponds to the region where synthesis of aqueous organic compounds in metastable states may be most easily detected. After Shock (1992).

acids, alcohols, and ketones (Seewald 2001; McCollom and Seewald 2003a,b; see McCollom 2013). Recently it was shown that many conversions between alkanes and alkenes, alkenes and alcohols, and alcohols and ketones are reversible reactions at temperatures and pressures of upper-crustal hydrothermal systems (Yang et al. 2012; Shipp et al. in press). Abundances of organic compounds in sedimentary basins suggest that, in some cases, metastable equilibrium states also include $\mathrm{CO}_{2}$ (Shock 1988, 1989, 1994; Helgeson et al. 1993), leading to the hypothesis that abiotic organic synthesis in hydrothermal systems proceeds from $\mathrm{CO}_{2}$ to organic compounds (Shock 1990, 1992; Shock and Schulte 1998; McCollom and Seewald 2007; Shock and Canovas 2010; McCollom 2013).

\section{Reduced carbon and aqueous fluids at high $P$ and $T$}

Burial metamorphism of organic compounds. Resilient compounds derived from plants (lignin) and microbes (long-chain carboxylic acids) progressively transform on burial. Because of the slow pace of methane formation, organic acids and other dissolved components that might not otherwise persist are added to coexisting fluid (and gas if present). There are many pathways for these transformations, and a host of products. Oxidation of organic carbon and decarboxylation of preexisting carboxyl groups in organic matter yield $\mathrm{CO}_{2}$. Small organic acids are released during petroleum and coal formation (followed, perhaps, by their decarboxylation). Hydrolytic disproportionation processes transform hydrocarbons. Alkanes, alkenes, alcohols, ketones, aldehydes, and other compounds are generated through aqueous organic transformation reactions. Finally, methane and other small organic compounds are released during the conversion of lignin to coal. While much attention has been focused on these transformations in the context of the origin and evolution of coal and petroleum deposits, the same processes operate on even small concentrations of organic matter that are insufficient to generate large deposits. 
Significantly, it is only in the last few decades that $\mathrm{H}_{2} \mathrm{O}$ has been recognized as a reactant or product involved in many of these organic transformations. This view challenges the traditional assumption that water is a passive participant in the physical movement of organic compounds in sedimentary basins (Hoering 1984; Shock 1988, 1989, 1994; Helgeson et al. 1993, 2009; Lewan 1997; Lewan and Ruble 2002; Lewan and Roy 2011; Reeves et al. 2012).

Lignin, which makes up plants' structural parts (e.g., wood), has evolved to be resistant to attack. The biosynthesis of lignin by plants starts with three aromatic alcohol building blocks (monolignols) that are derived from phenylalanine (see structures in Fig. 21). Biosynthetic processes in plant cells generate polymers of these alcohols through processes that are slowly being revealed (Davin and Lewis 2005). In the polymerization process, the overall stoichiometry of lignin structures largely reflects that of the monolignols, with only slight modifications. As a consequence, the model lignin molecules shown in Figure 21 plot near the locations of

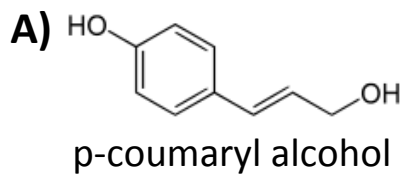

B)<smiles>COc1cc(/C=C/CO)ccc1O</smiles>

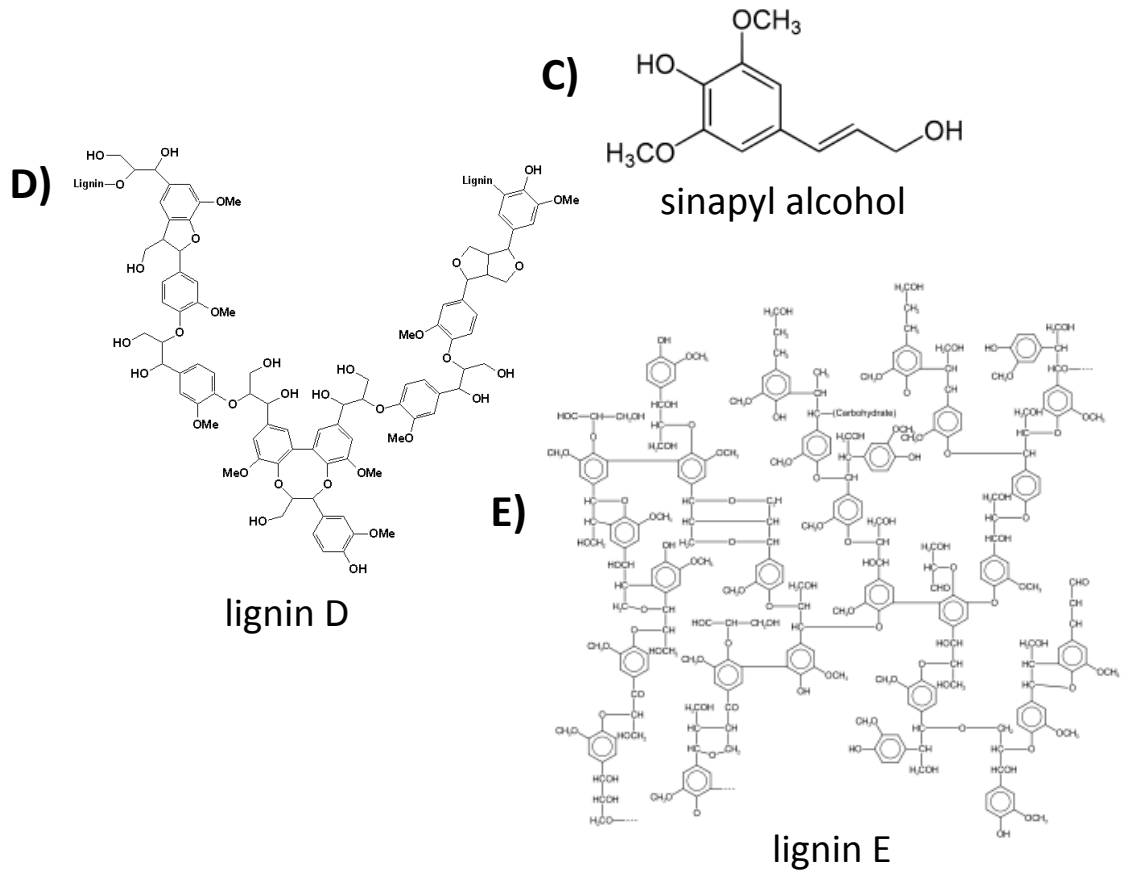

Figure 21. Structures of aromatic alcohols (A-C) that are the building blocks of lignin, and two model lignin structures (D-E). Lignin D has the overall stoichiometry of $\mathrm{C}_{90} \mathrm{H}_{93} \mathrm{O}_{33}$; that of $\mathrm{E}^{\text {is }} \mathrm{C}_{272} \mathrm{H}_{290} \mathrm{O}_{88}$. Both are plotted in the ternary diagram shown in Figure 22. 
the monolignols in the C-H-O ternary diagram shown in Figure 22. Taken together, the open symbols in Figure 22 represent the plant material available for incorporation into sedimentary basins.

In the case of lignin, burial in sedimentary basins leads to the generation of the lowrank coal lignite. Plotting compositions of lignin and lignite coal in Figure 22 reveals that the transformation of lignin to lignite is accompanied by a decrease in the relative abundance of hydrogen. The most direct pathway for hydrogen loss is by the liberation of methane. Note that a vector drawn from the location where methane plots in the diagram connects the compositions of buried plant material with those of lignite 1, the lowest ranking coal composition. Where it occurs, removal of methane from lignin pushes the residual solid composition toward lignite. Reference to Figure 21 shows that numerous methoxy $\left(-\mathrm{OCH}_{3}\right)$ groups are present in models for lignin, suggesting that methanol might also be a product of coal formation. The vector extending from methanol shows that lignin would evolve toward the composition of bituminous coal. Any combination of methane and methanol production during lignin transformation drives the residual solid material into the compositional range bounded by the arrowheads of the two solid vectors (Fig. 22). The methane and methanol produced will be dissolved in aqueous fluids that coexist with this organic transformation process, and some of the methane can also exist as natural gas.

Higher coal ranks-bituminous coal and anthracite-plot near the carbon apex of the ternary diagram shown in Figure 22. The transformation of lignite into these higher ranks of coal requires the removal of oxygen, which can occur in several ways, some more likely

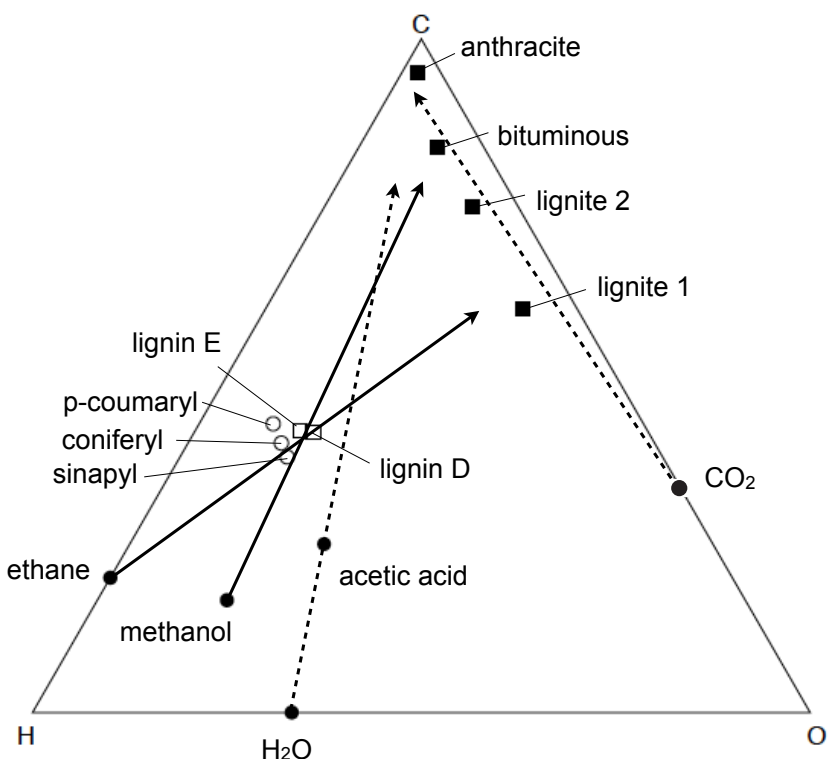

Figure 22. C-H-O ternary diagram showing the compositions of the monolignols from which lignin is synthesized by plants, the model lignin fragments shown in Fig. 21, and the composition of various coal compositions. Solid arrows show how loss of methane would drive the trajectories of the remaining solid organic matter as its composition transforms toward that of lignite coal. Increasing rank of coal from lignite to bituminous to anthracite requires loss of $\mathrm{O}$ and $\mathrm{H}$, which can be accomplished by dehydration, or by release of acetic acid as indicated by the dashed arrow. Combinations of these vectors outline the transition of lignin to coal in sedimentary basins, and require loss of methane and water or acetic acid, or perhaps other small organic solutes. 
than others. One is the release of $\mathrm{O}_{2}$; however, this process seems unlikely in highly reduced sedimentary basins, because if $\mathrm{O}_{2}$ were released it would likely react immediately with reduced constituents in the system (e.g., reduced forms of $\mathrm{S}, \mathrm{Fe}, \mathrm{N}$, or $\mathrm{C}$ ). Effective ways to remove oxygen during elevation of coal rank are the production of $\mathrm{CO}_{2}$ and/or $\mathrm{H}_{2} \mathrm{O}$, shown by dashed vectors in Figure 22. In the case of dehydration, numerous hydroxyl groups are candidates for this process (Fig. 21); however, acetic acid lies on this same vector, making it difficult to resolve the effects of dehydration from those resulting from acetic acid production. Fluids associated with some coal deposits are enriched in acetic and other small organic acids (Fisher and Boles 1990). In summary, the transformation reactions leading to coal accompany the alteration of lignin in any sedimentary rock. They lead to the release of methanol, acetic acid, other small organic solutes, and methane to sedimentary basin fluids.

Major resilient constituents of microbial membranes are long-chain carboxylic acids. It is widely thought that during the organic transformations that accompany burial and heating of sediments, these acids undergo decarboxylation. When a carboxyl group is cleaved from the rest of the molecule, $\mathrm{CO}_{2}$ and long-chain alkanes are generated (Cooper and Bray 1963; Jurg and Eisma 1964; Robinson 1966; Kvenvolden and Weiser 1967; Smith 1967; Shimoyama and Johns 1971, 1972; Philippi 1974; Snape et al. 1981; Kissin 1987; Hunt et al. 2002). Tie lines in Figure 23 show how several carboxylic acids (indicated by carbon numbers) can decarboxylate into $\mathrm{CO}_{2}$ and an alkane. As examples, acetic acid (2 in Fig. 23) produces $\mathrm{CO}_{2}$ and methane via

$$
\mathrm{CH}_{3} \mathrm{COOH} \rightarrow \mathrm{CH}_{4}+\mathrm{CO}_{2}
$$

and hexadecanoic acid (16 in Fig. 23) would yield $\mathrm{CO}_{2}$ and pentadecane via

$$
\mathrm{C}_{15} \mathrm{H}_{31} \mathrm{COOH} \rightarrow \mathrm{C}_{15} \mathrm{H}_{32}+\mathrm{CO}_{2}
$$

The products of decarboxylation reactions lie along the $\mathrm{C}-\mathrm{O}$ and $\mathrm{C}-\mathrm{H}$ binaries of the ternary diagram in Figure 23. This geometry emphasizes that decarboxylation is a disproportionation reaction, because in each case the products are one compound with bulk carbon oxidation state that is more oxidized $\left(\mathrm{CO}_{2}\right)$ and one with carbon that is more reduced (an alkane) than in the reacting acid.

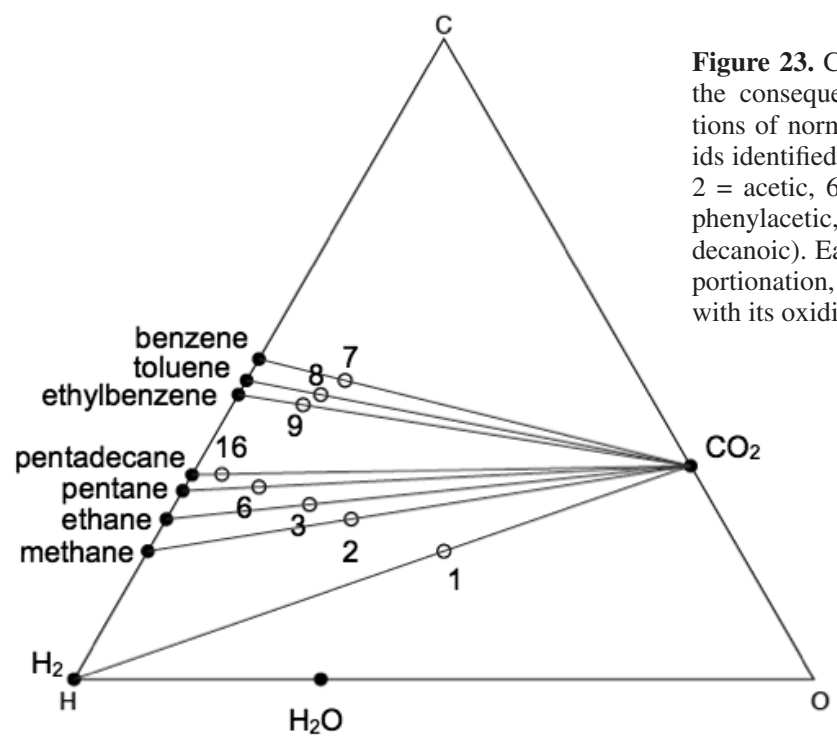


The production of hydrocarbons and $\mathrm{CO}_{2}$ by acid decarboxylation is advantageous to the geochemist, because organic acids are far more soluble in water than are hydrocarbons, and it is easier to model the chemistry and transport of aqueous acids as hydrocarbon precursors than it is to model the hydrocarbons themselves. Recognition of this situation led researchers to investigate the rates of carboxylic acid decarboxylation. Initial results showed highly variable rates depending on the composition of the experimental container used (Kharaka et al. 1983; Palmer and Drummond 1986). Palmer and Drummond (1987) determined that the least catalytic surface to use is gold, and that has been the standard for subsequent work. Early studies focused on acetic acid, which is among the most abundant organic acids found in oilfield brines and other deep fluids; rates were determined by quantifying its decreasing concentration (Kharaka et al. 1983). Subsequently, researchers attempted to show mass balance in their experiments, with the hope of demonstrating equal concentrations of methane and $\mathrm{CO}_{2}$ generated by the decarboxylation reaction (Eqn. 17). In some cases it could be argued that roughly similar abundances of methane and $\mathrm{CO}_{2}$ were produced, giving some confidence that decarboxylation rates could be established (Palmer and Drummond 1986; Bell and Palmer 1994; Bell et al. 1994). However, the composition of the experimental solution, the presence of minerals, and the presence or absence of a gas headspace in the experiments also allowed processes other than decarboxylation to occur. These variables were explored in detail by McCollom and Seewald (2003a,b), who used mineral assemblages to control the oxidation state of their experiments, and maintained careful control of mass balance.

When put to the test, the elegant simplicity of decarboxylation runs into difficulties in explaining the fate of organic acids in geologic fluids. As revealed by analysis of natural samples and laboratory experiments, the transformations undergone by aqueous organic compounds are more complicated. McCollom and Seewald (2003b) showed, for example, that the decarboxylation reaction could explain the fate of acetic acid in the presence of the assemblage pyrite + pyrrhotite + magnetite at $325{ }^{\circ} \mathrm{C}$ and $35 \mathrm{MPa}$, but that at the same conditions, the mineral assemblages hematite + magnetite or hematite + magnetite + pyrite drove the oxidation of carbon in acetic acid, probably via the overall reaction

$$
\mathrm{CH}_{3} \mathrm{COOH}+2 \mathrm{H}_{2} \mathrm{O} \rightarrow 2 \mathrm{CO}_{2}+4 \mathrm{H}_{2}
$$

McCollom and Seewald (2003b) also showed that, at the same conditions and in the presence of the same mineral assemblages, valeric acid $\left(\mathrm{C}_{4} \mathrm{H}_{9} \mathrm{COOH}\right)$ transformed by a variety of reaction pathways. One such pathway was the degradation of valeric acid to formic acid and butene $\left(\mathrm{C}_{4} \mathrm{H}_{8}\right)$ in the presence of hematite + magnetite, implying an overall reaction such as

$$
\mathrm{C}_{4} \mathrm{H}_{9} \mathrm{COOH} \rightarrow \mathrm{C}_{4} \mathrm{H}_{8}+\mathrm{HCOOH}
$$

At the high $P$ and $T$ of these experiments, formic acid rapidly converts to $\mathrm{CO}_{2}$ and $\mathrm{H}_{2}(\mathrm{McCollom}$ and Seewald 2001, 2003a; Seewald et al. 2006) via

$$
\mathrm{HCOOH} \rightarrow \mathrm{CO}_{2}+\mathrm{H}_{2}
$$

At more reduced conditions consistent with the pyrite + pyrrhotite + magnetite assemblage, McCollom and Seewald (2003b) showed that butene would be rapidly reduced to butane $\left(\mathrm{C}_{4} \mathrm{H}_{10}\right)$, via

$$
\mathrm{C}_{4} \mathrm{H}_{8}+\mathrm{H}_{2} \rightarrow \mathrm{C}_{4} \mathrm{H}_{10}
$$

which, together with the conversion of formic acid to $\mathrm{CO}_{2}$ (Eqn. 21), would produce the misleading appearance of direct decarboxylation.

As indicated by these reactions and reference to Figure 23, the generation of formic acid is not colinear with a carboxylic acid reactant and the alkane product containing one less carbon. As an example, a line connecting pentane $\left(\mathrm{C}_{5} \mathrm{H}_{12}\right)$ and formic acid $(\mathrm{HCOOH})$ would not pass through hexanoic acid $\left(\mathrm{C}_{5} \mathrm{H}_{11} \mathrm{COOH} ; 6\right.$ in Fig. 23). Instead, hexanoic acid plots above this line, 
implying that the addition of $\mathrm{H}_{2}$ is required in the overall reaction, which is indeed the case as given by

$$
\mathrm{C}_{5} \mathrm{H}_{11} \mathrm{COOH}+\mathrm{H}_{2} \rightarrow \mathrm{C}_{5} \mathrm{H}_{12}+\mathrm{HCOOH}
$$

If formic acid breakdown followed Equation (21), then $\mathrm{H}_{2}$ would be consumed and produced in the overall process, again giving the misleading impression of direct decarboxylation.

In principle, during transformation of membrane biomolecules it would also be possible for other $\mathrm{C}-\mathrm{C}$ bonds to be broken, allowing the formation of acetic, propanoic or other small carboxylic acids together with correspondingly shorter alkanes. The extent of decarboxylation, deformylation, and other reactions could then determine the fates of these acids, which tend to accumulate in oil-field brines and other aqueous fluids co-produced with petroleum (Shock 1988, 1989, 1994; Helgeson et al. 1993; Seewald 2001, 2003). The mechanisms of decarboxylation reactions at the molecular level are currently under investigation (Glein and Shock, unpublished data).

Reduced carbon in aqueous fluids at greater depths. Graphite is the dominant crystalline form of reduced carbon at conditions of the middle and lower crust and upper mantle. It may be produced by a variety of pathways, such as metamorphism of organic matter, reduction of carbonate minerals, partial melting, or infiltration of externally derived carbon-bearing fluids (Nokleberg 1973; Andreae 1974; Perry and Ahmad 1977; Rumble et al. 1977; Wada et al. 1994; Luque et al. 1998). The composition of fluids coexisting with graphite-bearing rocks varies strongly with $P, T$, fluid composition, and oxygen fugacity (French 1966; Ohmoto and Kerrick 1977; Huizenga 2001, 2011; Huizenga and Touret 2012). A simple way to explore variations in graphite solubility is to track variations in the graphite saturation surface in the C-O-H ternary system (Fig. 24). Each ternary diagram in Figure 24 is constructed at a fixed $P$ and $T$, but $f_{\mathrm{O}_{2}}$ varies with composition within the plot. The carbon content in a graphite-saturated fluid
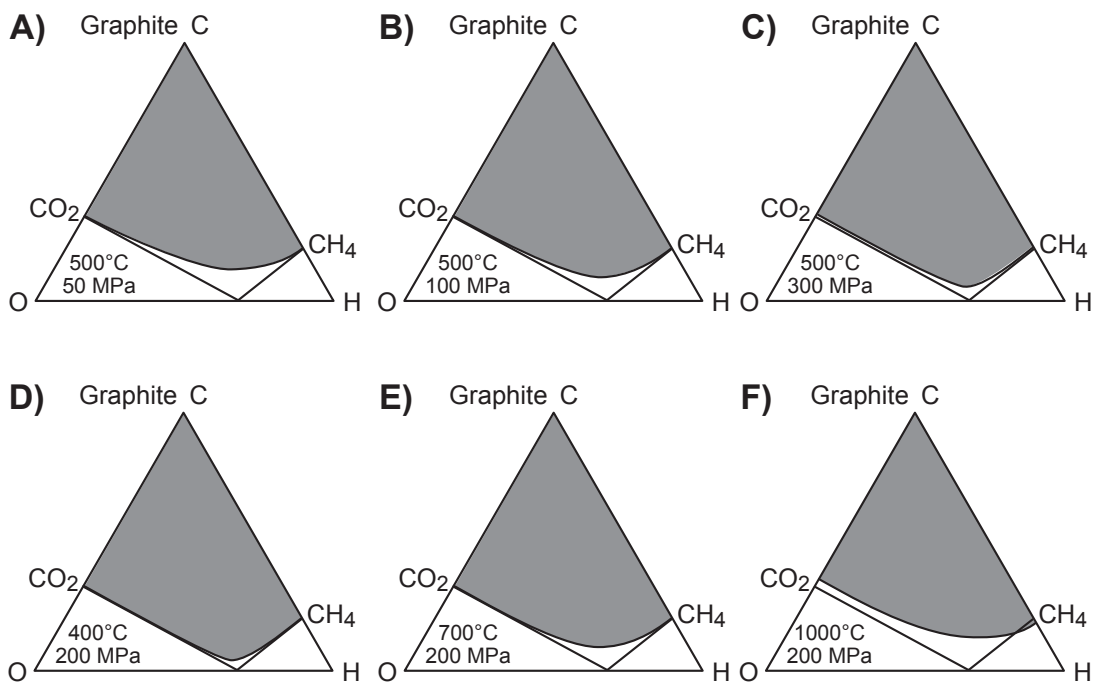

Figure 24. Predicted solubility of graphite in C-O-H fluids at a range of conditions of crustal metamorphism. Shaded region in each ternary (A-F) denotes the graphite + fluid stability field. Graphite solubility varies with fluid composition along the lower, curved boundary of the two-phase field and can be surprisingly high even in $\mathrm{H}_{2} \mathrm{O}$-rich fluids. Assumes ideal mixing of molecular species; after Spear (1993) and Ferry and Baumgartner (1987). 
corresponds to the curve passing from the $\mathrm{C}-\mathrm{O}$ binary to the $\mathrm{C}-\mathrm{H}$ binary. Figure 24 illustrates that graphite-saturated fluid composition is variable at fixed $P$ and $T$ : graphite solubility is lower in $\mathrm{CH}_{4}$-rich fluid than in $\mathrm{CO}_{2}$-rich fluid, and minimum graphite solubilities occur in initially pure $\mathrm{H}_{2} \mathrm{O}$. Comparison of the ternaries also confirms that graphite solubility varies with $P$ and $T$. An important conclusion to be drawn from the ternary diagrams is that, at many conditions, the solubility of graphite, nominally a refractory phase, can be surprisingly high.

In general, devolatilization of graphite-bearing rocks will produce dissolved, reduced carbon at a concentration limited by the solubility of graphite at the ambient $f_{\mathrm{O}_{2}}$. The relative abundance of carbon and its distribution among dominant carbon-bearing molecular components such as $\mathrm{CH}_{4}, \mathrm{CO}_{2}$, and $\mathrm{COS}$ species, will vary strongly with $P$ and $T$. For example, in the presence of graphite at relatively reducing conditions, a C-O-H-S fluid coexisting with the model mineral assemblage biotite $+\mathrm{K}$-feldspar + pyrite + pyrrhotite will have total carbon concentration and species abundances that are strong functions of $T$ at constant $P$ (Fig. 25; Ferry and Baumgartner, 1987). Carbon concentrations are higher at oxidizing conditions, where virtually all carbon is present as $\mathrm{CO}_{2}$.

Where reducing conditions prevail in the lower crust and upper mantle, the predominant dissolved form of carbon is generally $\mathrm{CH}_{4}$. This conclusion is supported by fluid inclusions containing $\mathrm{CH}_{4}$ from regional metamorphic terranes (e.g., Sisson and Hollister 1990; Huff and Nabelek 2007). Interestingly, $\mathrm{CH}_{4}$ appears to be quite common as a solute in subduction-zone settings (Zheng et al. 2000, 2003; Fu et al. 2001, 2002, 2003a,b; Shi et al. 2005).

Numerous studies have shown that $\mathrm{CH}_{4}$ (and hydrocarbons) can form at high pressures and temperatures (Kenney et al. 2002; Kutcherov et al. 2002; Scott et al. 2004; Kolesnikov et al. 2009; Sharma et al. 2009; Marocchi et al. 2011). But in many settings where $\mathrm{CH}_{4}$ is recorded as a component of metamorphic fluids, the temperature of entrapment does not exceed $500{ }^{\circ} \mathrm{C}$, which raises the question of why it has formed despite the kinetic inhibition of methane formation at these temperatures. Rates of abiogenic methanogenesis may be increased by catalysis involving mineral surfaces in the host rock. Much geochemical research on heterogeneous catalysis has been motivated by observations that abundant reduced gases
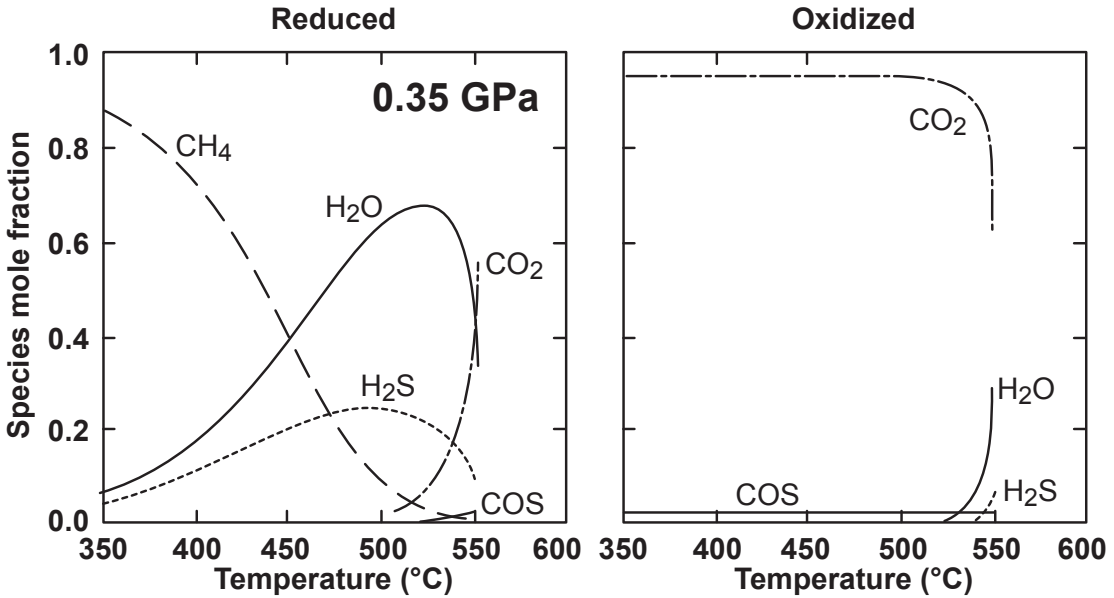

Figure 25. Fluid composition and species abundances in equilibrium with biotite $+\mathrm{K}$-feldspar + pyrite + pyrrhottite + graphite, as a function of temperature at $0.35 \mathrm{GPa}$. Fluid composition and speciation varies strongly from relatively reducing (left) to oxidizing (right) conditions. Assumes ideal mixing of molecular species; after Spear (1993) and Ferry and Baumgartner (1987). 
are produced during serpentinization of olivine-rich ultramafic rocks, with metal oxides, $\mathrm{Fe}$ $\mathrm{Ni}$ alloys, and Fe-Ni sulfides as byproducts (Schrenk et al. 2013). A range of experimental studies has demonstrated the effectiveness of these catalytic effects on accelerating the rate of alkanogenesis (Horita and Berndt 1999; Foustoukos and Seyfried 2004; Fu et al. 2008).

\section{CONCLUDING REMARKS}

Our understanding of the chemistry of aqueous carbon is advanced at conditions relevant for the shallow geologic environments; however, much remains to be done to extend this framework to the higher-pressure systems relevant to Earth's deep carbon cycle. Most progress has been made in development and application of equations of state for molecular fluids. Unfortunately, this simple framework is inadequate for treating many problems of mass transfer, where other species (ions, metal carbonates, organic acids, etc.) must be taken into account. The problem is compounded by limits in the application of $\mathrm{HKF}$ theory to $\leq 0.5 \mathrm{GPa}$, and relatively few experimental investigations at the requisite high pressures. This situation is especially true for reduced carbon species: even if such species are metastable with respect to $\mathrm{CH}_{4}$, the kinetic inhibition of $\mathrm{CH}_{4}$ formation means that they may be important in many deep systems of interest.

Nevertheless, recent advances hold promise for progress in this field. Developments of hydrothermal piston-cylinder and hydrothermal diamond-anvil cell approaches to mineral solubility and fluid characterization now allow for robust, routine experimental work at high $P$ and $T$. In addition, recognition of the comparative simplicity of $\mathrm{H}_{2} \mathrm{O}$ behavior at high $P$ and $T$ has led to exploitation of simple correlations of mineral solubility and homogeneous equilibria with $\mathrm{H}_{2} \mathrm{O}$ density. These advances are opening for the first time the realm of deep fluid flow to robust aqueous geochemical methods. The combined experimental and theoretical avenues thus promise new insights into the terrestrial deep carbon cycle in the coming years.

\section{ACKNOWLEDGMENTS}

We thank John Brodholt, Robert Newton and Codi Lazar for thorough reviews. Pam Hill and Edwin Schauble are thanked for jmol assistance. This work was supported by grants from the National Science Foundation (EAR-1049901 to CEM), the University of California Lab Research Program (CEM), the Department of Energy (DOE Grant DE-FG02-96ER-14616 to DAS), and the Deep Carbon Observatory.

\section{REFERENCES}

Adamczyk K, Prémont-Schwarz M, Pines D, Pines E, Nibbering ETJ (2009) Real-time observation of carbonic acid formation in aqueous solution. Science 326:1690-1694

Amend JP, Helgeson HC (1997) Group additivity equations of state for calculating the standard molal thermodynamic properties of aqueous organic species at elevated temperatures and pressures. Geochim Cosmochim Acta 61:11-46

Anderson AJ, Clark AH, Gray S (2001) The occurrence and origin of zabuyelite $\left(\mathrm{Li}_{2} \mathrm{CO}_{3}\right)$ in spodumene-hosted fluid inclusions: implications for the internal evolution of rare-element granitic pegmatites. Can Mineral 39:1513-1527

Anderson GM, Crerar DA (1993) Thermodynamics in Geochemistry: The Equilibrium Model. Oxford University Press, Oxford

Andreae MO (1974) Chemical and stable isotope composition of high-grade metamorphic rocks from Arendalarea, southern Norway. Contrib Mineral Petrol 47:299-316

Anovitz LM, Labotka TC, Blencoe JG, Horita J (2004) Experimental determination of the activity-composition relations and phase equilibria of $\mathrm{H}_{2} \mathrm{O}-\mathrm{CO}_{2}-\mathrm{NaCl}$ fluids at $500{ }^{\circ} \mathrm{C}, 500$ bars. Geochim Cosmochim Acta $68: 3557-3567$

Aranovich LY, Newton $\mathrm{RC}$ (1996) $\mathrm{H}_{2} \mathrm{O}$ activity in concentrated $\mathrm{NaCl}$ solutions at high pressures and temperatures measured by the brucite-periclase equilibrium. Contrib Mineral Petrol 125:200-212 
Aranovich LY, Newton RC (1999) Experimental determination of $\mathrm{CO}_{2}-\mathrm{H}_{2} \mathrm{O}$ activity-composition relations at $600-1000{ }^{\circ} \mathrm{C}$ and 6-14 kbar by reversed decarbonation and dehydration reactions. Am Mineral 84:13191332

Aranovich LY, Zakirov IV, Sretenskaya NG, Gerya TV (2010) Ternary system $\mathrm{H}_{2} \mathrm{O}-\mathrm{CO}_{2}-\mathrm{NaCl}$ at high T-P parameters: An empirical mixing model. Geochem Int 48:446-455

Audétat A, Pettke T, Dolejs D (2004) Magmatic anhydrite and calcite in the ore-forming quartz-monzodiorite magma at Santa Rita, New Mexico (USA): genetic constraints on porphyry-Cu mineralization. Lithos $72: 147-161$

Baratov RB, Gnutenko NA, Kuzemko VN (1984) Regional carbonization connected with the epi-Hercynian tectogenesis in the southern Tien Shan. Dokl Akad Nauk 274:124-126

Barrenechea JF, Luque FJ, Milward D, Ortega L, Beyssac O, Rodas M (2009) Graphite morphologies from the Borrowdale deposit (NW England, UK): Raman and SIMS data. Contrib Mineral Petrol 158:37-51

Becker JA, Bickle MJ, Galy A, Holland TJB (2008) Himalayan metamorphic $\mathrm{CO}_{2}$ fluxes: Quantitative constraints from hydrothermal springs. Earth Planet Sci Lett 265:616-629

Bell JLS, Palmer DA (1994) Experimental studies of organic acid decomposition. In: Organic Acids in Geological Processes Pittman ED, Lewan MD (eds) Springer-Verlag, Berlin, p 227-269

Bell JLS, Palmer DA, Barnes HL, Drummond SE (1994) Thermal decomposition of acetate: III. Catalysis by mineral surfaces. Geochim Cosmochim Acta 58:4155-4177

Bergman SC, Dubessy J (1984) $\mathrm{CO}_{2}$-CO fluid inclusions in a composite peridotite xenolith - implications for upper mantle oxygen fugacity. Contrib Mineral Petrol 85:1-13

Berkesi M, Guzmics T, Szabo C, Dubessy J, Bodnar RJ, Hidas K, Ratter K (2012) The role of $\mathrm{CO}_{2}$-rich fluids in trace element transport and metasomatism in the lithospheric mantle beneath the Central Pannonian Basin, Hungary, based on fluid inclusions in mantle xenoliths. Earth Planet Sci Lett 331-332:8-20

Berman RG (1988) Internally-consistent thermodynamic data for minerals in the system $\mathrm{Na}_{2} \mathrm{O}-\mathrm{K}_{2} \mathrm{O}-\mathrm{CaO}-\mathrm{MgO}-$ $\mathrm{FeO}-\mathrm{Fe}_{2} \mathrm{O}_{3}-\mathrm{Al}_{2} \mathrm{O}_{3}-\mathrm{SiO}_{2}-\mathrm{TiO}_{2}-\mathrm{H}_{2} \mathrm{O}-\mathrm{CO}_{2}$. J Petrol 29:445-522

Berner RA (1991) A model for atmospheric $\mathrm{CO}_{2}$ over Phanerozoic time. Am J Sci 291:339-376

Berner RA (1994) GEOCARB II: a revised model of atmospheric $\mathrm{CO}_{2}$ over Phanerozoic time. Am J Sci 294:5691

Berner RA, Kothavala Z (2001) GEOCARB III: a revised model of atmospheric $\mathrm{CO}_{2}$ over Phanerozoic time. Am J Sci 301:182-204

Berner RA, Lasaga AC, Garrels RM (1983) The carbonate-silicate geochemical cycle and its effect on atmospheric carbon dioxide over the past 100 million years. Am J Sci 283:641-683

Blundy J, Cashman KV, Rust A, Witham F (2010) A case for $\mathrm{CO}_{2}$-rich arc magmas. Earth Planet Sci Lett 290:289-301

Boettcher AL, Wyllie PJ (1968) The calcite-aragonite transition measured in the system $\mathrm{CaO}-\mathrm{CO}_{2}-\mathrm{H}_{2} \mathrm{O}$. J Geol 76:314-330

Bonatti E, Emiliani C, Ferrara G, Honnorez J, Rydell H (1974) Ultramafic-carbonate breccias from equatorial mid-Atlantic ridge. Marine Geol 16:83-102

Bonatti E, Lawrence JR, Hamlyn PR, Breger D (1980) Aragonite from deep-sea ultramafic rocks. Geochim Cosmochim Acta 44:1207-1214

Bowers TS, Helgeson HC (1983a) Calculation of the thermodynamic and geochemical consequences of nonideal mixing in the system $\mathrm{H}_{2} \mathrm{O}-\mathrm{CO}_{2}-\mathrm{NaCl}$ on phase relations in geologic systems: equation of state for $\mathrm{H}_{2} \mathrm{O}-\mathrm{CO}_{2}-\mathrm{NaCl}$ fluids at high pressures and temperatures. Geochim Cosmochim Acta 47:1247-1275

Bowers TS, Helgeson HC (1983b) Calculation of the thermodynamic and geochemical consequences of nonideal mixing in the system $\mathrm{H}_{2} \mathrm{O}-\mathrm{CO}_{2}-\mathrm{NaCl}$ on phase-relations in geologic systems - metamorphic equilibria at high-pressures and temperatures. Am Mineral 68:1059-1075

Brodholt J, Wood B (1993) Molecular-dynamics simulations of the properties of $\mathrm{CO}_{2}-\mathrm{H}_{2} \mathrm{O}$ mixtures at highpressures and temperatures. Am Mineral 78:558-564

Burton MR, Sawyer GM, Granieri D (2013) Deep carbon emissions from volcanoes. Rev Mineral Geochem 75:323-354

Caciagli NC, Manning CE (2003) The solubility of calcite in water at 6-16 kbar and 500-800 ${ }^{\circ} \mathrm{C}$. Contrib Mineral Petrol 146:275-285

Campos CEPS, Penello JR, Pessoa FLP, Uller AMC (2010) Experimental measurement and thermodynamic modeling for the solubility of methane in water and hexadecane. J Chem Eng Data 55:2576-2580

Charlou JL, Donval JP, Douville E, Jean-Baptiste P, Radford-Knoery J, Fouquet Y, Dapoigny A, Stievenard M (2000) Compared geochemical signatures and the evolution of Menez Gwen $\left(37^{\circ} 50^{\prime} \mathrm{N}\right)$ and Lucky Strike $\left(37^{\circ} 17^{\prime} \mathrm{N}\right)$ hydrothermal fluids, south of the Azores Triple Junction on the Mid-Atlantic Ridge. Chem Geol 171:49-75

Charlou JL, Fouquet Y, Bougault H, Donval JP, Etoubleau J, Jean-Baptiste P, Dapoigny A, Appriou P, Rona PA (1998) Intense $\mathrm{CH}_{4}$ plumes generated by serpentinization of ultramafic rocks at the intersection of the $15^{\circ} 20^{\prime} \mathrm{N}$ fracture zone and the Mid-Atlantic Ridge. Geochim Cosmochim Acta 62:2323-2333 
Chiodini G, Frondini F, Kerrick DM, Rogie J, Parello F, Peruzzi L, Zanzari AR (1999) Quantification of deep $\mathrm{CO}_{2}$ fluxes from Central Italy. Examples of carbon balance for regional aquifers and of soil diffuse degassing. Chem Geol 159:205-222

Chiodini G, Frondini F, Ponziani F (1995) Deep structures and carbon-dioxide degassing in central Italy. Geothermics 24:81-94

Claes P, Thirion B, Glibert J (1996) Solubility of $\mathrm{CO}_{2}$ in the molten $\mathrm{Na}_{2} \mathrm{CO}_{3}-\mathrm{K}_{2} \mathrm{CO}_{3}(42$ mol\%) eutectic mixture at $800{ }^{\circ} \mathrm{C}$. Electrochim Acta 41:141-146

Claussen WF, Polglase MF (1952) Solubilities and structures in aqueous aliphatic hydrocarbon solutions. J Am Chem Soc 74:4817-4819

Cooper JE, Bray EE (1963) A postulated role of fatty acids in petroleum formation. Geochim Cosmochim Acta 27:1113-1127

Cosgrove BA, Walkley J (1981) Solubilities of gases in $\mathrm{H}_{2} \mathrm{O}$ and ${ }^{2} \mathrm{H}_{2} \mathrm{O}$. J Chromatogr 216:161-167

Crovetto R, Fernandez-Prini R, Japas ML (1982) Solubilities of inert gases and methane in $\mathrm{H}_{2} \mathrm{O}_{\text {and }} \mathrm{D}_{2} \mathrm{O}$ in the temperature range of 300 to $600 \mathrm{~K}$. J Chem Phys 76:1077-1086

Dahlgren S, Bogoch R, Magaritz M, Michard A (1993) Hydrothermal dolomite marbles associated with charnockitic magmatism in the Proterozoic Bamble Shear Belt, south Norway. Contrib Mineral Petrol 113:394-408

Dasgupta R (2013) Ingassing, storage, and outgassing of terrestrial carbon through geologic time. Rev Mineral Geochem 75:183-229

Dasgupta R, Hirschmann MM (2006) Melting in the Earth's deep upper mantle caused by carbon dioxide. Nature 440:659-662

Dasgupta R, Hirschmann MM (2010) The deep carbon cycle and melting in Earth's interior. Earth Planet Sci Lett 298:1-13

Davin LB, Lewis NG (2005) Lignin primary structures and dirigent sites. Curr Opin Biotechnol 16:407-415

Davis AR, Oliver BG (1972) A vibrational-spectroscopic study of the species present in $\mathrm{CO}_{2}-\mathrm{H}_{2} \mathrm{O}$ system. J Solution Chem 1:329-338

Deines P (2002) The carbon isotope geochemistry of mantle xenoliths. Earth Sci Rev 58:247-278

Demeny A, Dallai L, Frezzotti ML, Vennemann TW, Embey-Isztin A, Dobosi G, Nagy G (2010) Origin of $\mathrm{CO}_{2}$ and carbonate veins in mantle-derived xenoliths in the Pannonian Basin. Lithos 117:172-182

Destrigneville CM, Brodholt JP, Wood BJ (1996) Monte Carlo simulation of $\mathrm{H}_{2} \mathrm{O}-\mathrm{CO}_{2}$ mixtures to $1073.15 \mathrm{~K}$ and 30 kbar. Chem Geol 133:53-65

Dick JM (2008) Calculation of the relative metastabilities of proteins using the CHNOSZ software package. Geochem Trans 9:10, doi: 10.1186/1467-4866-9-10

Dick JM, LaRowe DE, Helgeson HC (2006) Temperature, pressure, and electrochemical constraints on protein speciation: Group additivity calculation of the standard molal thermodynamic properties of ionized unfolded proteins. Biogeosciences 3:311-336

Dolejs D, Manning CE (2010) Thermodynamic model for mineral solubility in aqueous fluids: theory, calibration and application to model fluid-flow systems. Geofluids 10:20-40

Duan ZH, Moller N, Weare JH (1995) Equation of state for the $\mathrm{NaCl}-\mathrm{H}_{2} \mathrm{O}-\mathrm{CO}_{2}$ system - prediction of phaseequilibria and volumetric properties. Geochim Cosmochim Acta 59:2869-2882

Duan ZH, Moller N, Weare JH (1996) A general equation of state for supercritical fluid mixtures and molecular dynamics simulation of mixture PVTX properties. Geochim Cosmochim Acta 60:1209-1216

Dunai TJ, Touret JLR (1993) A noble gas study of a granulite sample from the Nilgiri Hills, southern India: implications for granulite formation. Earth Planet Sci Lett 119:271-281

Eggert RG, Kerrick DM (1981) Metamorphic equilibria in the siliceous dolomite system - 6 kbar experimental data and geologic implications. Geochim Cosmochim Acta 45:1039-1049

Einaudi MT, Meinert LD, Newberry RJ (1981) Skarn deposits. In: Economic Geology Seventy-Fifth Anniversary Volume. Skinner BJ (ed) The Economic Geology Publishing Company, New Haven, p 317-391

Ellis AJ (1959a) The effect of pressure on the first dissociation constant of "carbonic acid". J Chem Soc 1959:3689-3699

Ellis AJ (1959b) The solubility of calcite in carbon dioxide solutions. Am J Sci 257:354-365

Ellis AJ (1963) The solubility of calcite in sodium chloride solutions at high temperatures. Am J Sci 261:259267

England AH, Duffin AM, Schwartz CP, Uejio JS, Prendergast D, Saykally RJ (2011) On the hydration and hydrolysis of carbon dioxide. Chem Phys Lett 514:187-195

Evans K, Gordon RA, Mavrogenes JA, Tailby N (2009) The effect of $\mathrm{CO}_{2}$ on the speciation of RbBr in solution at temperatures of $579{ }^{\circ} \mathrm{C}$ and pressures of $0.26 \mathrm{GPa}$. Geochim Cosmochim Acta 73:2631-2644

Falcke H, Eberle SH (1990) Raman spectroscopic identification of carbonic acid. Water Res 24:685-688

Fein JB, Walther JV (1989) Calcite solubility and speciation in supercritical $\mathrm{NaCl}-\mathrm{HCl}$ aqueous fluids. Contrib Mineral Petrol 103:317-324

Fein JB, Wlather JV (1987) Calcite solubility in supercritical $\mathrm{CO}_{2}-\mathrm{H}_{2} \mathrm{O}$ fluids. Geochim Cosmochim Acta 51:1665-1673 
Fernandez DP, Goodwin ARH, Lemmon EW, Levelt Sengers JMH, Williams RC (1997) A formulation for the static permittivity of water and steam at temperatures from $238 \mathrm{~K}$ to $873 \mathrm{~K}$ at pressures up to $1200 \mathrm{MPa}$, including derivatives and Debye-Hückel coefficients. J Phys Chem Ref Data 26:1125-1166

Fernandez-Prini R, Crovetto R (1989) Evaluation of data on solubility of simple apolar gases in light and heavy water at high temperature. J Phys Chem Ref Data 18:1231-1243

Ferry JM, Baumgartner L (1987) Thermodynamic models of molecular fluids at the elevated pressures and temperatures of crustal metamorphism. Rev Mineral 17:323-365

Ferry JM, Ushikubo T, Valley JW (2011) Formation of forsterite by silicification of dolomite during contact metamorphism. J Petrol 52:1619-1640

Fisher JB, Boles JR (1990) Water-rock interaction in Tertiary sandstones, San Joaquin basin, California, U.S.A.: Diagenetic controls on water composition. Chem Geol 82:83-101

Foustoukos DI, Seyfried WE (2004) Hydrocarbons in hydrothermal vent fluids: The role of chromium-bearing catalysts. Science 304:1002-1005

Franck EU, Rosenzweig S, Christoforakos M (1990) Calculation of the dielectric constant of water to $1000{ }^{\circ} \mathrm{C}$ and very high pressures. Ber Bunsen Ges Phys Chem 94:199-203

Frantz JD (1998) Raman spectra of potassium carbonate and bicarbonate aqueous fluids at elevated temperatures and pressures: comparison with theoretical simulations. Chem Geol 152:211-225

Frantz JD, Popp RK, Hoering TC (1992) The compositional limits of fluid immiscibility in the system $\mathrm{H}_{2} \mathrm{O}-$ $\mathrm{CO}_{2}-\mathrm{NaCl}$ as determined with the use of synthetic fluid inclusions in conjunction with mass-spectrometry. Chem Geol 98:237-255

Frear GL, Johnston DH (1929) The solubility of calcium carbonate (calcite) in certain aqueous solutions at 25 ${ }^{\circ} \mathrm{C}$. J Am Chem Soc 51:2082-2092

French BM (1966) Some geological implications of equilibrium between graphite and a C-H-O gas at high temperatures and pressures. Rev Geophys 4:223-253

Frezzotti ML, Selverstone J, Sharp ZD, Compagnoni R (2011) Carbonate dissolution during subduction revealed by diamond-bearing rocks from the Alps. Nature Geosci 4:703-706

Frost DJ, Wood BJ (1997) Experimental measurements of the properties of $\mathrm{H}_{2} \mathrm{O}-\mathrm{CO}_{2}$ mixtures at high pressures and temperatures. Geochim Cosmochim Acta 61:3301-3309

Fu B, Touret JLR, Zheng YF (2001) Fluid inclusions in coesite-bearing eclogites and jadeite quartzite at Shuanghe, Dabie Shan (China). J Metamorph Geol 19:529-545

Fu B, Touret JLR, Zheng YF (2003a) Remnants of premetamorphic fluid and oxygen isotopic signatures in eclogites and garnet clinopyroxenite from the Dabie-Sulu terranes, eastern China. J Metamorph Geol 21:561-578

Fu B, Touret JLR, Zheng YF, Jahn BM (2003b) Fluid inclusions in granulites, granulitized eclogites and garnet clinopyroxenites from the Dabie-Sulu terranes, eastern China. Lithos 70:293-319

Fu B, Zheng YF, Touret JLR (2002) Petrological, isotopic and fluid inclusion studies of eclogites from Sujiahe, NW Dabie Shan (China). Chem Geol 187:107-128

Fu Q, Foustoukos DI, Seyfried WE (2008) Mineral catalyzed organic synthesis in hydrothermal systems: An experimental study using time-of-flight secondary ion mass spectrometry. Geophys Res Lett 35, doi: 10.1029/2008GL033389

Gao J, John T, Klemd R, Xiong XM (2007) Mobilization of Ti-Nb-Ta during subduction: evidence from rutilebearing dehydration segregations and veins hosted in eclogite, Tianshan, NW China. Geochim Cosmochim Acta 71:4974-4996

Garrels RM, Mackenzie FT (1971) Evolution of Sedimentary Rocks. Norton, New York

Gehrig M, Lentz H, Franck EU (1979) Thermodynamic properties of water-carbon dioxide-sodium chloride mixtures at high temperatures and pressures. In: High Pressure Science and Technology. Timmerhaus KD, Barber MS (eds) Plenum, New York, p 534-542

Gerlach TM, McGee KA, Elias T, Sutton AJ, Doukas MP (2002) Carbon dioxide emission rate of Kilauea Volcano: Implications for primary magma and the summit reservoir. J Geophys Res 107, doi: 10.1029/2001jb000407

Gibert F, Guillaume D, Laporte D (1998) Importance of fluid immiscibility in the $\mathrm{H}_{2} \mathrm{O}-\mathrm{NaCl}-\mathrm{CO}_{2}$ system and selective $\mathrm{CO}_{2}$ entrapment in granulites: experimental phase diagram at $5-7 \mathrm{kbar}, 900{ }^{\circ} \mathrm{C}$ and wetting textures. Eur J Mineral 10:1109-1123

Goff F, Arney BH, Eddy AC (1982) Scapolite phenocrysts in a latite dome, northwest Arizona, USA. Earth Planet Sci Lett 60:86-92

Gottschalk M (2007) Equations of state for complex fluids. Rev Mineral Geochem 65:49-97

Greenwood HJ (1967) Wollastonite - stability in $\mathrm{H}_{2} \mathrm{O}-\mathrm{CO}_{2}$ mixtures and occurence in a contact-metamorphic aureole near Salmo British Columbia, Canada. Am Mineral 52:1669-1680

Hazen RM, Downs RT, Jones AP, Kah L (2013) Carbon mineralogy and crystal chemistry. Rev Mineral Geochem 75:7-46

Heger K, Uematsu M, Franck EU (1980) The Static Dielectric Constant of Water at High Pressures and Temperatures to $500 \mathrm{MPa}$ and $550^{\circ} \mathrm{C}$. Ber Bunsen Ges Phys Chem 84:758-762 
Heinrich W (2007) Fluid immiscibility in metamorphic rocks. Rev Mineral Geochem 65:389-430

Heinrich W, Churakov SS, Gottschalk M (2004) Mineral-fluid equilibria in the system CaO-MgO- $\mathrm{SiO}_{2}-\mathrm{H}_{2} \mathrm{O}-$ $\mathrm{CO}_{2}-\mathrm{NaCl}$ and the record of reactive fluid flow in contact metamorphic aureoles. Contrib Mineral Petrol 148:131-149

Helgeson HC, Kirkham DH (1974a) Theoretical prediction of the thermodynamic behavior of aqueous electrolytes at high pressures and temperatures: I. summary of the thermodynamic/electrostatic properties of the solvent. Am J Sci 274:1089-1198

Helgeson HC, Kirkham DH (1974b) Theoretical prediction of the thermodynamic behavior of aqueous electrolytes at high pressures and temperatures: II. Debye-Hückel parameters for activity coefficients and relative partial molal properties. Am J Sci 274:1199-1261

Helgeson HC, Kirkham DH, Flowers GC (1981) Theoretical prediction of the thermodynamic behavior of aqueous electrolytes at high pressures and temperatures: IV. Calculation of activity coefficients, osmotic coefficients, and apparent molal and standard and relative partial molal properties to $600^{\circ} \mathrm{C}$ and $5 \mathrm{~kb}$. Am J Sci 281:1249-1516

Helgeson HC, Knox AM, Owens CE, Shock EL (1993) Petroleum, oil-field waters, and authigenic mineral assemblages - are they in metastable equilibrium in hydrocarbon reservoirs. Geochim Cosmochim Acta 57:3295-3339

Helgeson HC, Richard L, McKenzie WF, Norton DL, Schmitt A (2009) A chemical and thermodynamic model of oil generation in hydrocarbon source rocks. Geochim Cosmochim Acta 73:594-695

Hoering TC (1984) Thermal reactions of kerogen with added water, heavy water and pure organic substances. Organic Geochem 5:267-278

Holland TJB, Powell R (1991) A compensated-Redlich-Kwong (CORK) equation for volumes and fugacities of $\mathrm{CO}_{2}$ and $\mathrm{H}_{2} \mathrm{O}$ in the range 1 bar to $50 \mathrm{kbar}$ and $100-1600{ }^{\circ} \mathrm{C}$. Contrib Mineral Petrol 109:265-273

Horita J, Berndt ME (1999) Abiogenic methane formation and isotopic fractionation under hydrothermal conditions. Science 285:1055-1057

Huff TA, Nabelek PI (2007) Production of carbonic fluids during metamorphism of graphitic pelites in a collisional orogen - An assessment from fluid inclusions. Geochim Cosmochim Acta 71:4997-5015

Huizenga JM (2001) Thermodynamic modelling of C-O-H fluids. Lithos 55:101-114

Huizenga JM (2011) Thermodynamic modelling of a cooling C-O-H fluid-graphite system: implications for hydrothermal graphite precipitation. Mineral Dep 46:23-33

Huizenga JM, Touret JLR (2012) Granulites, $\mathrm{CO}_{2}$ and graphite. Gondwana Res 22:799-809

Hunt JE, Philp RP, Kvenvolden KA (2002) Early developments in petroleum geochemistry. Organic Geochem 9:1025-1052

Irwin WP (1970) Metamorphic waters from the Pacific tectonic belt of the west coast of the United States. Science 168:973-975

Jacobs GK, Kerrick DM (1981a) Devolatilization equilibria in $\mathrm{H}_{2} \mathrm{O}-\mathrm{CO}_{2}$ and $\mathrm{H}_{2} \mathrm{O}-\mathrm{CO}_{2}-\mathrm{NaCl}$ fluids: an experimental and thermodynamic evaluation at elevated pressures and temperatures. Am Mineral 66:11351153

Jacobs GK, Kerrick DM (1981b) Methane: An equation of state with application to the ternary system $\mathrm{H}_{2} \mathrm{O}$ $\mathrm{CO}_{2}-\mathrm{CH}_{4}$. Geochim Cosmochim Acta 45:607-614

Janecky DR, Seyfried WE (1986) Hydrothermal serpentinization of peridotite within the oceanic-crust experimental investigations of mineralogy and major element chemistry. Geochim Cosmochim Acta 50:1357-1378

Johannes WP, Puhan D (1971) The calcite-aragonite transition, reinvestigated. Contrib Mineral Petrol 31:28-38

Johnson EL (1991) Experimentally determined limits for $\mathrm{H}_{2} \mathrm{O}-\mathrm{CO}_{2}-\mathrm{NaCl}$ immiscibility in granulites. Geology 19:925-928

Johnson JW, Oelkers EH, Helgeson HC (1992) SUPCRT92: A software package for calculating the standard molal thermodynamic properties of minerals, gases, aqueous species, and reactions from 1 to 5000 bar and 0 to $1000{ }^{\circ} \mathrm{C}$. Comput Geosci 18:899-947

Jones AP, Genge M, Carmody L (2013) Carbonate melts and carbonatites. Rev Mineral Geochem 75:289-322

Joyce DB, Holloway JR (1993) An experimental-determination of the thermodynamic properties of $\mathrm{H}_{2} \mathrm{O}_{-} \mathrm{CO}_{2}$ $\mathrm{NaCl}$ fluids at high-pressures and temperatures. Geochim Cosmochim Acta 57:733-746

Jurg JW, Eisma E (1964) Petroleum hydrocarbons: generation from fatty acid. Science 144:1451-1452

Kenney JF, Kutcherov VA, Bendeliani NA, Alekseev VA (2002) The evolution of multicomponeint systems at high pressures: VI. The thermodynamic stability of the hydrogen-carbon system: The genesis of hydrocarbons and the origin of petroleum. Proc Natl Acad Sci USA 99:10976-10981

Keppler H, Wiedenbeck M, Shcheka SS (2003) Carbon solubility in olivine and the mode of carbon storage in the Earth's mantle. Nature 424:414-416

Kerrick DM, Jacobs GK (1981) A modified Redlich-Kwong equation for $\mathrm{H}_{2} \mathrm{O}, \mathrm{CO}_{2}$, and $\mathrm{H}_{2} \mathrm{O}-\mathrm{CO}_{2}$ mixtures at elevated pressures and temperatures. Am J Sci 281:735-767

Kharaka YK, Carothers WW, Rosenbauer RJ (1983) Thermal decarboxylation of acetic acid: Implications for origin of natural gas. Geochim Cosmochim Acta 47:397-402 
Kissin YV (1987) Catagenesis and composition of petroleum: Origins of $n$-alkanes and isoalkanes in petroleum crudes. Geochim Cosmochim Acta 51:2445-2457

Kolesnikov A, Kutcherov VG, Goncharov AF (2009) Methane-derived hydrocarbons produced under uppermantle conditions. Nature Geosci 2:566-570

Koster van Groos AF, Wyllie $\mathrm{PJ}$ (1968) Liquid immiscibility in the join $\mathrm{NaAlSi}_{3} \mathrm{O}_{8}-\mathrm{Na}_{2} \mathrm{CO}_{3}-\mathrm{H}_{2} \mathrm{O}$ and its bearing on the genesis of carbonatites. Am J Sci 266:932-967

Kotelnikov AR, Kotelnikova ZA (1990) Experimental-study of phase state of the system $\mathrm{H}_{2} \mathrm{O}-\mathrm{CO}_{2}-\mathrm{NaCl}$ by method of synthetic fluid inclusions in quartz. Geokhimiya 1990:526-537

Kruse R, Franck EU (1982) Raman spectra of hydrothermal solutions of $\mathrm{CO}_{2}$ and $\mathrm{HCO}_{3}$ at high temperatures and pressures. Ber Bunsen Ges Phys Chem 86:1036-1038

Kutcherov VG, Bendeliani NA, Alekseev VA, Kenney JF (2002) Synthesis of hydrocarbons from minerals at pressures up to $5 \mathrm{GPa}$. Dokl Phys Chem 387:328-330

Kvenvolden KA, Weiser D (1967) A mathematical model of a geochemical process: Normal paraffin formation from normal fatty acids. Geochim Cosmochim Acta 31:1281-1309

Lamb WM, Valley JW (1987) Post-metamorphic $\mathrm{CO}_{2}$-rich inclusions in granulites. Contrib Mineral Petrol 96:485-495

Lapin AV, Ploshko VV, Malyshev AA (1987) Carbonatites of the Tatar deep-seated fault zone, Siberia. Int Geol Rev 29:551-567

Lennie AR (2005) Ikaite $\left(\mathrm{CaCO}_{3} \cdot 6 \mathrm{H}_{2} \mathrm{O}\right)$ compressibility at high water pressure: a synchrotron X-ray diffraction study. Mineral Mag 69:325-335

Lewan MD (1997) Experiments on the role of water in petroleum formation. Geochim Cosmochim Acta 61:3691-3723

Lewan MD, Roy S (2011) Role of water in hydrocarbon generation from Type-I kerogen in Mahogany oil shale of the Green River Formation. Organic Geochem 42:31-41

Lewan MD, Ruble TE (2002) Comparison of petroleum generation kinetics by isothermal hydrous and nonisothermal open-system pyrolysis. Organic Geochem 33:1457-1475

Liebscher A (2007) Experimental studies in model fluid systems. Fluid-Fluid Interactions 65:15-47

Liebscher A (2010) Aqueous fluids at elevated pressure and temperature. Geofluids 10:3-19

Loerting T, Tautermann C, Kroemer RT, Kohl I, Hallbrucker A, Mayer E, Liedl KR (2000) On the Surprising Kinetic Stability of Carbonic Acid $\left(\mathrm{H}_{2} \mathrm{CO}_{3}\right)$. Angew Chem Int Ed 39:891-894

Ludwig R, Kornath A (2000) In spite of the chemist's belief: Carbonic acid is surprisingly stable. Angew Chem Int Ed 39:1421-1423

Luque FJ, Pasteris JD, Wopenka B, Rodas M, Barrenechea JF (1998) Natural fluid-deposited graphite: Mineralogical characteristics and mechanisms of formation. Am J Sci 298:471-498

Malinin SD, Kanukov AB (1972) The solubility of calcite in homogeneous $\mathrm{H}_{2} \mathrm{O}-\mathrm{NaCl}-\mathrm{CO}_{2}$ systems in the 200600 degrees $\mathrm{C}$ temperature interval. Geochem Int 8:668-679

Manning CE (1994) The solubility of quartz in $\mathrm{H}_{2} \mathrm{O}$ in the lower crust and upper-mantle. Geochim Cosmochim Acta 58:4831-4839

Manning CE (1998) Fluid composition at the blueschist-eclogite transition in the model system $\mathrm{Na}_{2} \mathrm{O}-\mathrm{MgO}-$ $\mathrm{Al}_{2} \mathrm{O}_{3}-\mathrm{SiO}_{2}-\mathrm{H}_{2} \mathrm{O}-\mathrm{HCl}$. Schweiz Mineral Petrol Mitt 78:225-242

Manning CE (2004) The chemistry of subduction-zone fluids. Earth Planet Sci Lett 223:1-16

Marocchi M, Bureau H, Fiquet G, Guyot F (2011) In-situ monitoring of the formation of carbon compounds during the dissolution of iron(II) carbonate (siderite). Chem Geol 290:145-155

Marshall WL, Franck EU (1981) Ion product of water substance, $0-1000{ }^{\circ} \mathrm{C}, 1-10,000$ bars: new international formulation and its background. J Phys Chem Ref Data 10:295-304

Martinez I, Sanchez-Valle C, Daniel I, Reynard B (2004) High-pressure and high-temperature Raman spectroscopy of carbonate ions in aqueous solution. Chem Geol 207:47-58

Marty B, Tolstikhin IN (1998) $\mathrm{CO}_{2}$ fluxes from mid-ocean ridges, arcs and plumes. Chem Geol 145:233-248

Mathez EA (1987) Carbonaceous matter in mantle xenoliths - composition and relevance to the isotopes. Geochim Cosmochim Acta 51:2339-2347

Mathez EA, Dietrich VJ, Irving AJ (1984) The geochemistry of carbon in mantle peridotites. Geochim Cosmochim Acta 48:1849-1859

Mathez EA, Mogk DM (1998) Characterization of carbon compounds on a pyroxene surface from a gabbro xenolith in basalt by time-of-flight secondary ion mass spectrometry. Am Mineral 83:918-924

McCollom TM (2013) Laboratory simulations of abiotic hydrocarbon formation in Earth's deep subsurface. Rev Mineral Geochem 75:467-494

McCollom TM, Seewald JS (2001) A reassessment of the potential for reduction of dissolved $\mathrm{CO}_{2}$ to hydrocarbons during serpentinization of olivine. Geochim Cosmochim Acta 65:3769-3778

McCollom TM, Seewald JS (2003a) Experimental constraints on the hydrothermal reactivity of organic acids and acid anions: I. Formic acid and formate. Geochim Cosmochim Acta 67:3625-3644

McCollom TM, Seewald JS (2003b) Experimental study of the hydrothermal reactivity of organic acids and acid anions: II. Acetic acid, acetate, and valeric acid. Geochim Cosmochim Acta 67:3645-3664 
McCollom TM, Seewald JS (2007) Abiotic synthesis of organic compounds in deep-sea hydrothermal environments. Chem Rev 107:382-401

McGetchin TR, Besancon JR (1973) Carbonate inclusions in mantle-derived pyropes. Earth Planet Sci Lett 18:408-410

Melton CE, Giardini AA (1974) Composition and significance of gas released from natural diamonds from Africa and Brazil. Am Mineral 59:775-782

Melton CE, Giardini AA, Salotti CA (1972) Observation of nitrogen, water, carbon-dioxide, methane and argon as impurities in natural diamonds. Am Mineral 57:1518-1523

Metz P, Trommsdorff V (1968) On phase equilibria in metamorphosed siliceous dolomites. Contrib Mineral Petrol 18:305-309

Miller JP (1952) A portion of the system calcium carbonate-carbon dioxide-water, with geological implications. Am J Sci 250:161-203

Mittwede SK (1994) Primary scapolite in a granitic pegmatite, western Cherokee County, South Carolina. Can Mineral 32:617-622

Morey GW (1962) The action of water on calcite, magnesite and dolomite. Am Mineral 47:1456-1460

Morgan JK, Milliken KL (1996) Petrography of calcite veins in serpentinized peridotite basement rocks from the Iberia Abyssal Plain, sites 897 and 899: Kinematic and environmental implications. Proc Ocean Drilling Prog, Sci Results 149:553-558

Mori T, Suma K, Sumiyoshi Y, Endo Y (2011) Spectroscopic detection of the most stable carbonic acid, cis-cis $\mathrm{H}_{2} \mathrm{CO}_{3}$. J Chem Phys 134, doi:10.1063/1.3532084

Morrison TJ, Billett F (1952) The salting-out of non-electrolytes. Part II. The effect of variations in nonelectrolyte. J Chem Soc 1952:3819-3822, doi:10.1039/jr95200038193819-3822

Murck BW, Burruss RC, Hollister LS (1978) Phase-equilibria in fluid inclusions in ultramafic xenoliths. Am Mineral 63:40-46

Navon O, Hutcheon ID, Rossman GR, Wasserburg GJ (1988) Mantle-derived fluids in diamond microinclusions. Nature 335:784-789

Newton RC, Aranovich LY, Hansen EC, Vandenheuvel BA (1998) Hypersaline fluids in Precambrian deepcrustal metamorphism. Precambrian Res 91:41-63

Newton RC, Manning CE (2002a) Experimental determination of calcite solubility in $\mathrm{H}_{2} \mathrm{O}-\mathrm{NaCl}$ solutions at deep crust/ upper mantle pressures and temperatures: Implications for metasomatic processes in shear zones. Am Mineral 87:1401-1409

Newton RC, Manning CE (2002b) Solubility of silica in equilibrium with enstatite, forsterite, and $\mathrm{H}_{2} \mathrm{O}$ at deep crust/upper mantle pressures and temperatures and an activity-concentration model for polymerization of aqueous silica. Geochim Cosmochim Acta 66:4165-4176

Newton RC, Manning CE (2003) Activity coefficient and polymerization of aqueous silica at $800{ }^{\circ} \mathrm{C}, 12 \mathrm{kbar}$, from solubility measurements on $\mathrm{SiO}_{2}$-buffering mineral assemblages. Contrib Mineral Petrol 146:135143

Newton RC, Manning CE (2005) Solubility of anhydrite, CaSO4, in NaCl-H2O solutions at high pressures and temperatures: applications to fluid-rock interaction. J Petrol 46:701-716

Newton RC, Manning CE (2009) Hydration state and activity of aqueous silica in $\mathrm{H}_{2} \mathrm{O}-\mathrm{CO}_{2}$ fluids at high pressure and temperature. Am Mineral 94:1287-1290

Newton RC, Manning CE (2010) Role of saline fluids in deep-crustal and upper-mantle metasomatism: insights from experimental studies. Geofluids 10:58-72

Newton RC, Smith JV, Windley BF (1980) Carbonic metamorphism, granulites and crustal growth. Nature 288:45-50

Ni H, Keppler H (2013) Carbon in silicate melts. Rev Mineral Geochem 75:251-287

Nokleberg WJ (1973) $\mathrm{CO}_{2}$ as a source of oxygen in metasomatism of carbonates. Am J Sci 273:498-514

Ohmoto H, Kerrick D (1977) Devolatilization equilibria in graphitic systems. Am J Sci 277:1013-1044

Oliver NHS, Cartwright I, Wall VJ, Golding SD (1993) The stable isotope signature of kilometer-scale fracturedominated metamorphic fluid pathways, Mary Kathleen, Australia. J Metamorph Geol 11:705-720

Oppenheimer C (2003) Volcanic degassing. In: The Crust, Vol. 3. Treatise on Geochemistry. Rudnick RL Holland HD, Turekian KK (eds) Elsevier-Pergamon, Oxford, p 123-166

Palmer DA, Drummond SE (1986) Thermal decarboxylation of acetate. Part I. The kinetics and mechanism of reaction in aqueous solution. Geochim Cosmochim Acta 50:813-823

Palmer DA, Drummond SE (1987) Thermodynamics of the formation of ferrous acetate complexes. J Electrochem Soc 134:C506-C506

Perry EC Jr, Ahmad SN (1977) Carbon isotope composition of graphite and carbonate minerals from 3.8-AE metamorphosed sediments, Isukasia, Greenland. Earth Planet Sci Lett 36:280-284

Philippi GT (1974) The influence of marine and terrestrial source material on the composition of petroleum. Geochim Cosmochim Acta 38:947-966

Pineau F, Mathez EA (1990) Carbon isotopes in xenoliths from the Hhualalai volcano, Hawaii, and the generation of isotopic variability. Geochim Cosmochim Acta 54:217-227 
Pitzer KS (1983) Dielectric constant of water at very high temperature and pressure. Proc Natl Acad Sci USA 80:4575-4576

Plank T, Langmuir CH (1998) The chemical composition of subducting sediment and its consequences for the crust and mantle. Chem Geol 145:325-394

Plummer LN, Busenberg E (1982) The solubilities of calcite, aragonite and vaterite in $\mathrm{CO}_{2}-\mathrm{H}_{2} \mathrm{O}$ solutions between 0 and $90{ }^{\circ} \mathrm{C}$, and an evaluation of the aqueous model for the system $\mathrm{CaCO}_{3}-\mathrm{CO}_{2}-\mathrm{H}_{2} \mathrm{O}$. Geochim Cosmochim Acta 46:1011-1040

Plyasunov AV, Shock EL (2001) Correlation strategy for determining the parameters of the revised HelgesonKirkham-Flowers model for aqueous nonelectrolytes. Geochim Cosmochim Acta 65:3879-3900

Price LC (1979) Aqueous solubility of methane at elevated pressures and temperatures. AAPG Bull 63:15271533

Read AJ (1975) The first ionization constant of carbonic acid from 25 to $250{ }^{\circ} \mathrm{C}$ and to 2000 bar. J Solution Chem 4:53-70

Reeves EP, Seewald JS, Sylva SP (2012) Hydrogen isotope exchange between n-alkanes and water under hydrothermal conditions. Geochim Cosmochim Acta 77:582-599

Rettich TR, Handa YP, Battino R, Wilhelm E (1981) Solubility of gases in liquids. 13. High-precision determination of Henry's constants for methane and ethane in liquid water at 275 to $328 \mathrm{~K}$. J Phys Chem 85:3230-3237

Richard L (2001) Calculation of the standard molal thermodynamic properties as a function of temperature and pressure of some geochemically important organic sulfur compounds. Geochim Cosmochim Acta 65:3827-3877

Rimstidt JD (1997) Gangue mineral transport and deposition. In: Geochemistry of Hydrothermal Ore Deposits. 3rd ed. Barnes HL (ed) John Wiley and Sons, New York, p 487-515

Robinson R (1966) The origins of petroleum. Nature 212:1291-1295

Roedder $\mathrm{E}$ (1965) Liquid $\mathrm{CO}_{2}$ inclusions in olivine-bearing nodules and phenocrysts from basalts. Am Mineral 50:1746-1782

Roedder E (1984) Fluid inclusions. Rev Mineral 12:1-644

Rumble D, III, Hoering TC, Grew ES (1977) The relation of carbon isotopic composition to graphitization of carbonaceous materials from the Narragansett Basin, Rhode Island. Carnegie Inst Wash Yearbook 76:623625

Ryzhenko BN (1963) Dissociation constant values of carbonic acid at elevated temperatures. Dokl Akad Nauk 149:639-641

Sanchez-Valle C, Martinez I, Daniel I, Philippot P, Bohic S, Simonovici A (2003) Dissolution of strontianite at high P-T conditions: an in-situ synchrotron X-ray fluorescence study. Am Mineral 88:978-985

Schloemer VH (1952) Hydrothermale Untersuchungen über das System CaO-MgO- $\mathrm{CO}_{2}-\mathrm{H}_{2} \mathrm{O}$. Neues Jarhb Mineral Monatsch 1952:129-135

Schrauder M, Navon O (1993) Solid carbon dioxide in a natural diamond. Nature 365:42-44

Schrenk MO, Brazelton WJ, Lang SQ (2013) Serpentinization, carbon, and deep life. Rev Mineral Geochem 75:575-606

Scott HP, Hemley RJ, Mao HK, Herschbach DR, Fried LE, Howard WM, Bastea S (2004) Generation of methane in the Earth's mantle: In situ high pressure-temperature measurements of carbonate reduction. Proc Natl Acad Sci USA 101:14023-14026

Seewald JS (1994) Evidence for metastable equilibrium between hydrocarbons under hydrothermal conditions. Nature 370:285-287

Seewald JS (2001) Aqueous geochemistry of low molecular weight hydrocarbons at elevated temperatures and pressures: Constraints from mineral buffered laboratory experiments. Geochim Cosmochim Acta 65:16411664

Seewald JS (2003) Organic-inorganic interactions in petroleum-producing sedimentary basins. Nature 426:327333

Seewald JS, Zolotov MY, McCollom T (2006) Experimental investigation of single carbon compounds under hydrothermal conditions. Geochim Cosmochim Acta 70:446-460

Segnit ER, Holland HD, Biscardi CJ (1962) The solubility of calcite in aqueous solutions -I. The solubility of calcite in water between $75^{\circ}$ and $200^{\circ}$ at $\mathrm{CO}_{2}$ pressures up to $60 \mathrm{~atm}$. Geochim Cosmochim Acta 26:13011331

Seitz JC, Blencoe JG (1999) The $\mathrm{CO}_{2}-\mathrm{H}_{2} \mathrm{O}$ system. I. Experimental determination of volumetric properties at $400^{\circ} \mathrm{C}, 10-100 \mathrm{MPa}$. Geochim Cosmochim Acta 63:1559-1569

Sephton MA, Hazen RM (2013) On the origins of deep hydrocarbons. Rev Mineral Geochem 75:449-465

Sharma A, Cody GD, Hemley RJ (2009) In situ diamond-anvil cell observations of methanogenesis at high pressures and temperatures. Energy Fuels 23:5571-5579

Sharp WE, Kennedy GC (1965) The system CaO- $\mathrm{CO}_{2}-\mathrm{H}_{2} \mathrm{O}$ in the two-phase region calcite+aqueous solution. J Geol 73:391-403 
Shaw DM (1956) Geochemistry of pelitic rocks. 3. Major elements and general geochemistry. Bull Geol Soc Am 67:919-934

Shcheka SS, Wiedenbeck M, Frost DJ, Keppler H (2006) Carbon solubility in mantle minerals. Earth Planet Sci Lett 245:730-742

Shi GU, Tropper P, Cui WY, Tan J, Wang CQ (2005) Methane $\left(\mathrm{CH}_{4}\right)$-bearing fluid inclusions in the Myanmar jadeitite. Geochem J 39:503-516

Shimoyama A, Johns WD (1971) Catalytic conversion of fatty acids to petroleum-like paraffins and their maturation. Nature-Phys Sci 232:140-144

Shimoyama A, Johns WD (1972) Formation of alkanes from fatty acids in the presence of $\mathrm{CaCO}_{3}$. Geochim Cosmochim Acta 36:87-91

Shipp J, Gould I, Herckes P, Shock EL, Williams L, Hartnett H (in press) Organic functional group transformations in water at elevated temperature and pressure: Reversibility, reactivity, and mechanisms. Geochim Cosmochim Acta

Shiryaev AA, Griffin WL, Stoyanov E (2011) Moissanite (SiC) from kimberlites: Polytypes, trace elements, inclusions and speculations on origin. Lithos 122:152-164

Shmulovich KI, Graham CM (1999) An experimental study of phase equilibria in the system $\mathrm{H}_{2} \mathrm{O}-\mathrm{CO}_{2}-\mathrm{NaCl}$ at $800{ }^{\circ} \mathrm{C}$ and 9 kbar. Contrib Mineral Petrol 136:247-257

Shmulovich KI, Graham CM (2004) An experimental study of phase equilibria in the systems $\mathrm{H}_{2} \mathrm{O}-\mathrm{CO}_{2-}$ $\mathrm{CaCl}_{2}$ and $\mathrm{H}_{2} \mathrm{O}-\mathrm{CO}_{2}-\mathrm{NaCl}$ at high pressures and temperatures $\left(500-800{ }^{\circ} \mathrm{C}, 0.5-0.9 \mathrm{GPa}\right)$ : geological and geophysical applications. Contrib Mineral Petrol 146:450-462

Shmulovich KI, Yardley BWD, Graham C M (2006) Solubility of quartz in crustal fluids: experiments and general equations for salt solutions and $\mathrm{H}_{2} \mathrm{O}-\mathrm{CO}_{2}$ mixtures at $400-800^{\circ} \mathrm{C}$ and $0.1-0.9 \mathrm{GPa}$. Geofluids 6:154-167

Shock E, Canovas P (2010) The potential for abiotic organic synthesis and biosynthesis at seafloor hydrothermal systems. Geofluids 10:161-192

Shock EL (1988) Organic-acid metastability in sedimentary basins. Geology 16:886-890

Shock EL (1989) Corrections to "Organic-acid metastability in sedimentary basins". Geology 17:572-573

Shock EL (1990) Geochemical constraints on the origin of organic compounds in hydrothermal systems. Origins Life Evol Biosphere 20:331-367

Shock EL (1992) Chemical environments of submarine hydrothermal systems. Orig Life Evol Biosph 22:67-107

Shock EL (1994) Application of thermodynamic calculations to geochemical processes involving organic acids. In: The Role of Organic Acids in Geological Processes. Lewan M, Pittman E (eds) Springer-Verlag, p 270-318

Shock EL (1995) Organic acids in hydrothermal solutions: Standard molal thermodynamic properties of carboxylic acids and estimates of dissociation constants at high temperatures and pressures. Am J Sci 295:496-580

Shock EL, Helgeson HC (1988) Calculation of the thermodynamic and transport properties of aqueous species at high pressures and temperatures: correlation algorithms for ionic species and equation of state predictions to $5 \mathrm{~kb}$ and $1000{ }^{\circ} \mathrm{C}$. Geochim Cosmochim Acta 52:2009-2036

Shock EL, Helgeson HC (1990) Calculation of the thermodynamic and transport properties of aqueous species at high pressures and temperatures: Standard partial molal properties of organic species. Geochim Cosmochim Acta 54:915-945

Shock EL, Helgeson HC, Sverjensky DA (1989) Calculation of the thermodynamic and transport properties of aqueous species at high pressures and temperatures: standard partial molal properties of inorganic neutral species. Geochim Cosmochim Acta 53:2157-2183

Shock EL, McKinnon WB (1993) Hydrothermal processing of cometary volatiles - applications to Triton. Icarus 106:464-477

Shock EL, Oelkers EH, Johnson JW, Sverjensky DA, Helgeson HC (1992) Calculation of the thermodynamic and transport properties of aqueous species at high pressures and temperatures: Effective electrostatic radii to $1000^{\circ} \mathrm{C}$ and $5 \mathrm{~kb}$. Faraday Soc Trans $88: 803-826$

Shock EL, Sassani DC, Betz H (1997a) Uranium in geologic fluids: Estimates of standard partial molal properties, oxidation potentials and hydrolysis constants at high temperatures and pressures. Geochim Cosmochim Acta 61:4245-4266

Shock EL, Sassani DC, Willis M, Sverjensky DA (1997b) Inorganic species in geologic fluids: correlations among standard molal thermodynamic properties of aqueous ions and hydroxide complexes. Geochim Cosmochim Acta 61:907-950

Shock EL, Schulte MD (1998) Organic synthesis during fluid mixing in hydrothermal systems. J Geophys Res Planets 103:28513-28527

Sirbescu MLC, Nabelek PI (2003a) Crustal melts below $400{ }^{\circ} \mathrm{C}$. Geology 31:685-688

Sirbescu MLC, Nabelek PI (2003b) Crystallization conditions and evolution of magmatic fluids in the Harney Peak Granite and associated pegmatites, Black Hills, South Dakota-evidence from fluid inclusions. Geochim Cosmochim Acta 67:2443-2465 
Sisson VB, Hollister LS (1990) A fluid-inclusion study of metamorphosed pelitic and carbonate rocks, southcentral Maine. Am Mineral 75:59-70

Skippen G, Trommsdorff V (1986) The influence of $\mathrm{NaCl}$ and $\mathrm{KCl}$ on phase-relations in metamorphosed carbonate rocks. Am J Sci 286:81-104

Skippen GB (1971) Experimental data for reactions in siliceous marbles. J Geol 79:457-481

Smith GC, Holness MB, Bunbury JM (2008) Interstitial magmatic scapolite in glass-bearing crystalline nodules from the Kula Volcanic Province, Western Turkey. Mineral Mag 72:1243-1259

Smith HM (1967) The hydrocarbon constituents of petroleum and some possible lipid precursors. J Am Oil Chem Soc 44:680-690

Snape CE, Stokes BJ, Bartle KD (1981) Identification o straight-chain fatty acids in coal extracts and their geochemical relation with straight-chain alkanes. Fuel 60:903-908

Soli AL, Byrne $\mathrm{RH}$ (2002) $\mathrm{CO}_{2}$ system hydration and dehydration kinetics and the equilibrium $\mathrm{CO}_{2} / \mathrm{H}_{2} \mathrm{CO}_{3}$ ratio in aqueous $\mathrm{NaCl}$ solution. Marine Chem 78:65-73

Spear FS (1993) Metamorphic Phase Equilibria and Pressure-Temperature-Time Paths. Mineralogical Society of America, Washington, D. C.

Staudigel H (2003) Hydrothermal alteration processes in the oeanic crust. In: The Crust, Vol. 3. Treatise on Geochemistry. Rudnick RL Holland HD, Turekian KK (eds) Elsevier-Pergamon, Oxford, p 511-535

Stern RJ, Gwinn CJ (1990) Origin of Late Precambrian intrusive carbonates, eastern desert of Egypt and Sudan: $\mathrm{C}, \mathrm{O}$ and $\mathrm{Sr}$ isotope evidence. Precambrian Res 46:259-272

Sterner SM, Bodnar RJ (1991) Synthetic fluid inclusions. X: Experimental-determination of P-V-T-X properties in the $\mathrm{CO}_{2}-\mathrm{H}_{2} \mathrm{O}$ system to $6 \mathrm{~kb}$ and $700{ }^{\circ} \mathrm{C}$. Am J Sci 291:1-54

Sverjensky DA, Shock EL, Helgeson HC (1997) Prediction of the thermodynamic properties of aqueous metal complexes to $1000{ }^{\circ} \mathrm{C}$ and $5 \mathrm{~kb}$. Geochim Cosmochim Acta 61:1359-1412

Swanson SE (1979) The effect of $\mathrm{CO}_{2}$ on phase equilibria and crystal growth in the system $\mathrm{KAlSi}_{3} \mathrm{O}_{8}-\mathrm{NaAlSi}_{3} \mathrm{O}_{8}-$ $\mathrm{CaAl}_{2} \mathrm{Si}_{2} \mathrm{O}_{8}-\mathrm{SiO}_{2}-\mathrm{H}_{2} \mathrm{O}-\mathrm{CO}_{2}$ to 8000 bars. Am J Sci 279:703-720

Symonds RB, Rose WI, Bluth GJS, Gerlach TM (1994) Volcanic-gas studies: methods, results, and applications. Rev Mineral 30:1-66

Takenouchi S, Kennedy GC (1964) Binary system $\mathrm{H}_{2} \mathrm{O}-\mathrm{CO}_{2}$ at high temperatures + pressures. Am J Sci 262:1055-1074

Terlouw JK, Lebrilla CB, Schwarz $\mathrm{H}$ (1987) Thermolysis of $\mathrm{NH}_{4} \mathrm{HCO}_{3}-\mathrm{A}$ simple route to the formation of free carbonic acid $\left(\mathrm{H}_{2} \mathrm{CO}_{3}\right)$ in the gas phase. Angew Chem Int Ed 26:354-355

Thomas R, Davidson P, Schmidt C (2011) Extreme alkali bicarbonate- and carbonate-rich fluid inclusions in granite pegmatite from the Precambrian Rønne granite, Bornholm Island, Denmark. Contrib Mineral Petrol 161:315-329

Thomas R, Webster JD, Davidson P (2006) Understanding pegmatite formation: the melt and fluid inclusion approach. In: Melt Inclusions in Plutonic Rocks. Webster JD (ed) Mineralogical Association of Canada, p 189-210

Thompson G (1972) Geochemical study of some lithified carbonate sediments from deep-sea. Geochim Cosmochim Acta 36:1237-1253

Thompson G, Bowen VT, Melson WG, Cifelli R (1968) Lithified carbonates from deep-sea of equatorial Atlantic. J Sed Pet 38:1305-1312

Tingle TN, Green HW (1987) Carbon solubility in olivine - implications for upper mantle evolution. Geology $15: 324-326$

Tingle TN, Green HW, Finnerty AA (1988) Experiments and observations bearing on the solubility and diffusivity of carbon in olivine. J Geophys Res 93:15289-15304

Todheide K, Franck EU (1963) Das Zweiphasengebiet und die kritische Kurve im System Kohlendioxyd-Wasser bei hohen Drucken. Ber Bunsen Ges Phys Chem 67:836-836

Tomilenko AA, Chepurov AI, Pal'Yanov YN, Shebanin AP, Sobolev NV (1998) Hydrocarbon inclusions in synthetic diamonds. Eur J Mineral 10:1135-1141

Tossell JA (2006) $\mathrm{H}_{2} \mathrm{CO}_{3}$ and its oligomers: Structures, stabilities, vibrational and NMR spectra, and acidities. Inorg Chem 45:5961-5970

Touret JLR (1985) Fluid regime in southern Norway: the record of fluid inclusions. In: The Deep Proterozoic Crust in the North Atlantic Provinces. Tobi AC, Touret JLR (eds) Reidel, Dordecht, p 517-549

Trommsdorff V, Evans BW, Pfeifer HR (1980) Ophicarbonate rocks - metamorphic reactions and possible origin. Arch Sci 33:361-364

Trommsdorff V, Skippen G (1986) Vapor loss (boiling) as a mechanism for fluid evolution in metamorphic rocks. Contrib Mineral Petrol 94:317-322

Tropper P, Manning CE (2007) The solubility of fluorite in $\mathrm{H}_{2} \mathrm{O}$ and $\mathrm{H}_{2} \mathrm{O}-\mathrm{NaCl}$ at high pressure and temperature. Chem Geol 242:299-306

Urey HC (1952) The Planets, Their Origin and Development. Yale University Press, New Haven 
Wada H, Tomita T, Matsuura K, Iuchi K, Ito M, Morikiyo T (1994) Graphitization of carbonaceous matter during metamorphism with references to carbonate and pelitic rocks of contact and regional metamorphisms, Japan. Contrib Mineral Petrol 118:217-228

Wallace PJ (2005) Volatiles in subduction zone magmas: concentrations and fluxes based on melt inclusion and volcanic gas data. J Volcan Geotherm Res 140:217-240

Walther JV (1992) Ionic association in $\mathrm{H}_{2} \mathrm{O}-\mathrm{CO}_{2}$ fluids at mid-crustal conditions. J Metamorph Geol 10:789-797

Walther JV, Helgeson HC (1980) Description and interpretation of metasomatic phase relations at high pressures and temperatures: 1 . equilibrium activities of ionic species in nonideal mixtures of $\mathrm{CO}_{2}$ and $\mathrm{H}_{2} \mathrm{O}$. Am $\mathrm{J}$ Sci 280:575-606

Walther JV, Long MI (1986) Experimental determination of calcite solubilities in supercritical $\mathrm{H}_{2} \mathrm{O}$. Int Symp Water-Rock Interaction 5:609-611

Walther JV, Schott J (1988) The dielectric constant approach to speciation and ion pairing at high temperature and pressure. Nature 332:635-638

Wells RC (1915) The solubility of calcite in water in contact with the atmosphere and its variation with temperature. J Wash Acad Sci 5:617-622

Wheat CG, Fryer P, Fisher AT, Hulme S, Jannasch H, Mottl MJ, Becker K (2008) Borehole observations of fluid flow from South Chamorro Seamount, an active serpentinite mud volcano in the Mariana forearc. Earth Planet Sci Lett 267:401-409

Wickham SM, Janardhan AS, Stern RJ (1994) Regional carbonate alteration of the crust by mantle-derived magmatic fluids, Tamil Nadu, South India. J Geol 102:379-398

Wilhelm E, Battino R, Wilcock RJ (1977) Low-pressure solubility of gases in liquid water. Chem Rev 77:219262

Yang Z, Gould IR, Williams L, Hartnett H, Shock EL (2012) The central role of ketones in reversible and irreversible hydrothermal organic functional group transformations. Geochim Cosmochim Acta 98:48-65

Yardley BWD, Valley JW (1997) The petrologic case for a dry lower crust. J Geophys Res 102:12,173-12,185

Zeller KP, Schuler P, Haiss P (2005) The hidden equilibrium in aqueous sodium carbonate solutions - evidence for the formation of dicarbonate anion. Eur J Inorg Chem 1:168-172

Zhang C, Duan ZH (2009) A model for C-O-H fluid in the Earth's mantle. Geochim Cosmochim Acta 73:20892102

Zhang C, Duan ZH, Zhang Z (2007) Molecular dynamics simulation of the $\mathrm{CH}_{4}$ and $\mathrm{CH}_{4}-\mathrm{H}_{2} \mathrm{O}$ systems up to 10 GPa and 2573 K. Geochim Cosmochim Acta 71:2036-2055

Zhang YG, Frantz JD (1989) Experimental-determination of the compositional limits of immiscibility in the system $\mathrm{CaCl}_{2}-\mathrm{H}_{2} \mathrm{O}-\mathrm{CO}_{2}$ at high-temperatures and pressures using synthetic fluid inclusions. Chem Geol 74:289-308

Zheng YF, Gong B, Li YL, Wang ZR, Fu B (2000) Carbon concentrations and isotopic ratios of eclogites from the Dabie and Sulu terranes in China. Chem Geol 168:291-305

Zheng YF, Gong B, Zhao ZF, Fu B, Li YL (2003) Two types of gneisses associated with eclogite at Shuanghe in the Dabie terrane: carbon isotope, zircon U-Pb dating and oxygen isotope. Lithos 70:321-343

Zotov N, Keppler H (2000) In-situ Raman spectra of dissolved silica species in aqueous fluids to $900{ }^{\circ} \mathrm{C}$ and 14 kbar. Am Mineral 85:600-604

Zotov N, Keppler H (2002) Silica speciation in aqueous fluids at high pressures and high temperatures. Chem Geol 184:71-82 